Review

\title{
Early Events in Japanese Encephalitis Virus Infection: Viral Entry
}

\author{
Sang-Im Yun and Young-Min Lee * (1) \\ Department of Animal, Dairy, and Veterinary Sciences, College of Agriculture and Applied Sciences, \\ Utah State University, Logan, UT 84322, USA; sangim.yun@usu.edu \\ * Correspondence: youngmin.lee@usu.edu; Tel.: +1-435-797-9667
}

Received: 1 June 2018; Accepted: 6 August 2018; Published: 13 August 2018

check for updates

\begin{abstract}
Japanese encephalitis virus (JEV), a mosquito-borne zoonotic flavivirus, is an enveloped positive-strand RNA virus that can cause a spectrum of clinical manifestations, ranging from mild febrile illness to severe neuroinvasive disease. Today, several killed and live vaccines are available in different parts of the globe for use in humans to prevent JEV-induced diseases, yet no antivirals are available to treat JEV-associated diseases. Despite the progress made in vaccine research and development, JEV is still a major public health problem in southern, eastern, and southeastern Asia, as well as northern Oceania, with the potential to become an emerging global pathogen. In viral replication, the entry of JEV into the cell is the first step in a cascade of complex interactions between the virus and target cells that is required for the initiation, dissemination, and maintenance of infection. Because this step determines cell/tissue tropism and pathogenesis, it is a promising target for antiviral therapy. JEV entry is mediated by the viral glycoprotein E, which binds virions to the cell surface (attachment), delivers them to endosomes (endocytosis), and catalyzes the fusion between the viral and endosomal membranes (membrane fusion), followed by the release of the viral genome into the cytoplasm (uncoating). In this multistep process, a collection of host factors are involved. In this review, we summarize the current knowledge on the viral and cellular components involved in JEV entry into host cells, with an emphasis on the initial virus-host cell interactions on the cell surface.
\end{abstract}

Keywords: Japanese encephalitis virus; flavivirus; viral replication; viral entry; attachment; binding; endocytosis; internalization; membrane fusion; virus-host interaction

\section{Introduction: JEV Is a Mosquito-Borne Neurotropic Flavivirus}

Japanese encephalitis virus (JEV) is a member of the genus Flavivirus, family Flaviviridae [1,2]. Most flaviviruses replicate in both hematophagous arthropod vectors (i.e., mosquitoes and ticks) and vertebrate animal hosts (e.g., mammals and birds) [3-7], but some infect only arthropods (e.g., mosquitoes and sand flies) or almost exclusively vertebrates (e.g., bats and rodents) [8-12]. Based on the host range and choice of vector species, flaviviruses can be divided into four groups [10-12]: mosquito-borne, tick-borne, arthropod-restricted, and vertebrate-restricted viruses, of which the last group is commonly referred to as no known vector viruses. Many of the mosquitoand tick-borne flaviviruses are the major emerging and re-emerging pathogens that present a global challenge to human and animal medicine [13-16]. Of the mosquito-borne flaviviruses, JEV is the prototype member of the Japanese encephalitis (JE) serogroup [17] that also includes the West Nile virus (WNV), Murray Valley encephalitis virus (MVEV), St. Louis encephalitis virus (SLEV), and four other lesser known flaviviruses, namely the Usutu virus, Koutango virus, Yaounde virus, and Cacipacore virus $[18,19]$. Although antigenically distinct, JEV is genetically close to several medically important mosquito-borne flaviviruses, such as the Zika virus (ZIKV), dengue virus (DENV), and yellow fever virus (YFV) [19-21], as well as the tick-borne encephalitis virus (TBEV) [22]. 
JEV is the etiological agent of JE, a serious neurological disease characterized by extensive inflammation in the central nervous system [23,24]. JE is the most common form of viral encephalitis occurring in the Asia-Pacific region, particularly in southern, eastern, and southeastern Asia, as well as northern Oceania [25-29]. Initially seen in Japan, outbreaks of "summer encephalitis", presumably caused by JEV infection, were described as early as 1871, but it was not until 1924 that the first cases of JE were diagnosed [30]. Since then, JEV has become prevalent in much of Asia, with a fatality rate of up to $\sim 30 \%$ [31] despite multiple JE vaccines having been made commercially available in this region [32]: Its geographic boundaries have continued to expand southward into Papua New Guinea $[33,34]$ and Australia [35-40], eastward through the Pacific Islands [41], and westward into Pakistan [42] and China (Tibet) $[43,44]$. Surprisingly, in Italy, JEV RNA was detected by RT-PCR assays in dead birds during 1997-2000 and field-collected mosquitoes in 2010 [45,46], raising concern regarding the long-distance spread of the virus from the Asia-Pacific region and its potential autochthonous transmission in Europe [47]. Likewise, the emergence of JEV in the Western Hemisphere is also conceivable [48].

\section{JEV Is a Zoonotic Pathogen Capable of Infecting a Wide Range of Animal Species}

JEV is transmitted among multiple vertebrate hosts primarily through the bite of an infected mosquito. In most Asian countries, Culex tritaeniorhynchus is known as the primary mosquito vector for JEV transmission [49-54]; in Australia, on the other hand, $C x$. annulirostris is identified as the main vector involved in the introduction and spread of JEV [36-38,55]. Also, JEV has been isolated or detected, albeit at various frequencies, in other wild-caught $C$ ulex mosquitoes (e.g., $C x$. annulus, $C x$. bitaeniorhynchus, $C x$. fuscocephala, $C x$. gelidus, $C x$. orientalis, $C x$. pipiens, $C x$. pseudovishnui, $C x$. quinquefasciatus, and $C x$. vishnui), suggesting that they may play a role in local JEV transmission $[45,50$, 52,53,55-64]. Similarly, recent experimental studies on the vector competence of European mosquitoes have shown that $C x$. pipiens and three Aedes species (Ae. albopictus, Ae. detritus, and Ae. japonicus) are susceptible to JEV infection in a laboratory setting [65-67]. Moreover, JEV infection has been detected in field-collected or experimentally inoculated non-Culex mosquitoes, such as Ae. albopictus, Ae. vexans, Armigeres subalbatus, and Mansonia uniformis, and three Anopheles species (An. minimus, An. sinensis, and An. tessellatus), raising the question of whether they can act as potential vectors under certain environmental conditions $[50,68,69]$. Furthermore, JEV can be passed directly from an infected female Culex or non-Culex mosquito to her eggs, suggesting the transovarial transmission as a mechanism by which the virus overwinters in the environment [70-73]. In addition, in terms of non-vector-borne transmission, a recent report has indicated that JEV can be transmitted through the transfusion of contaminated blood products [74].

The natural cycle of JEV involves numerous vertebrate hosts. In Asia, domestic pigs and water birds have been recognized as the two most important JEV-amplifying hosts, since they are generally asymptomatic following infection, but develop high-titer viremias sufficient to transmit the virus to engorging mosquitoes [75-82]. In sows, it is noteworthy that JEV infection during pregnancy often causes abortions and stillbirths [83-86]. Bats, along with migratory birds, may play a role in the overwintering and dispersal of JEV, as suggested by detection of the virus and its IgG antibody [87-92]. On the other hand, horses, like humans, are considered to be incidental hosts that sometimes develop fatal encephalitis following JEV infection, but are not believed to be a significant source of the virus for mosquitoes, although they may occasionally develop viremia that allows mosquito infection, because of their small population size and long generation time [93-101]. In cows, JEV rarely causes neurological disorders [102-106], and little or no viremia is typically detected [107]. Serological surveys and experimental infection studies have suggested that JEV can subclinically infect other vertebrate animals, such as dogs, goats, sheep, buffaloes, boars, raccoons, raccoon dogs, ducks, and chickens [108-114], underlining the need to investigate their potential roles in JEV ecology [115]. Notably, ducklings and chicks under two weeks of age have been shown to develop considerably high viremias following JEV infection, but the development of viremia is inversely correlated with the age of the animals at infection [116]. Interestingly, JEV-infected pigs are demonstrated to shed the 
virus in oronasal secretions [117] and transmit it to co-housed naive pigs in the absence of mosquitoes, suggesting a mode of viral transmission during mosquito-free seasons [118]. Further studies are needed to understand the dynamic interactions between the virus, mosquito vectors, and vertebrate hosts under certain geo-environmental and eco-agricultural conditions [119-121].

\section{JEV Is a Small Enveloped Positive-Strand RNA Virus}

\subsection{Genome Structure and Gene Expression}

JEV is an enveloped RNA virus with a linear, single-stranded, and positive-sense RNA genome of $\sim 11 \mathrm{~kb}$ in length (Figure 1A). The genomic RNA has a methylated cap structure at its $5^{\prime}$ end, but lacks a poly (A) tail at the $3^{\prime}$ end [122-126]. It has one long open reading frame (ORF) encoded between the two short, but highly structured, $5^{\prime}$ and $3^{\prime}$ non-coding regions (NCRs) that form a long-range intramolecular RNA-RNA interaction to regulate viral translation and RNA replication [127-131]. In addition to the viral genomic RNA, a group of short non-coding subgenomic RNAs $(\sim 0.2-0.5 \mathrm{~kb})$ is also accumulated to high levels in a diverse range of mammalian and insect cells infected with JEV and other flaviviruses as a result of incomplete degradation of the genomic RNA caused by the stalling of the cellular $5^{\prime} \rightarrow 3^{\prime}$ exoribonuclease Xrn1 just upstream of a higher-order structure in the $3^{\prime} \mathrm{NCR}$ [132-136]. The generation of this subgenomic RNA may cause the suppression of Xrn1 and the dysregulation of cellular mRNA stability [137], thereby disrupting the host's innate immune responses and contributing to viral replication and pathogenesis [138-140].

The ORF in the JEV genomic RNA encodes a polyprotein precursor of $\sim 3432$ amino acids, which is cleaved into at least 10 distinct products [141,142], i.e., three structural (capsid, C; premembrane, prM; and envelope, E) and seven nonstructural (NS1, NS2A, NS2B, NS3, NS4A, NS4B, and NS5) proteins (Figure 1B,C). In flaviviruses, the site-specific proteolysis of the polyprotein is catalyzed coand post-translationally by a set of four different proteases: (i) the host signal peptidase responsible for cleaving at the C-prM, prM-E, E-NS1, and NS4A-NS4B junctions within the lumen of the endoplasmic reticulum (ER) [143-148]; (ii) the two-component viral protease NS3 + NS2B [149] required for cleaving at the NS2A-NS2B, NS2B-NS3, NS3-NS4A, and NS4B-NS5 junctions, as well as at internal sites within the $C$ and NS4A proteins on the cytoplasmic face of the ER membrane [143,144,150-155]; (iii) the host furin or furin-like protease mediating the final cleavage of prM to $\mathrm{M}$ in the trans-Golgi network [156]; and (iv) an unknown host protease capable of cleaving at the NS1-NS2A junction [157-159]. In addition to the aforementioned 10 proteins, an NS1 isoform ( $\mathrm{NS1}^{\prime}$ ) is also produced during infection with JEV and other JE serogroup members as a result of -1 translational frameshifting occurring at codons 8-9 of NS2A [160-163]. 


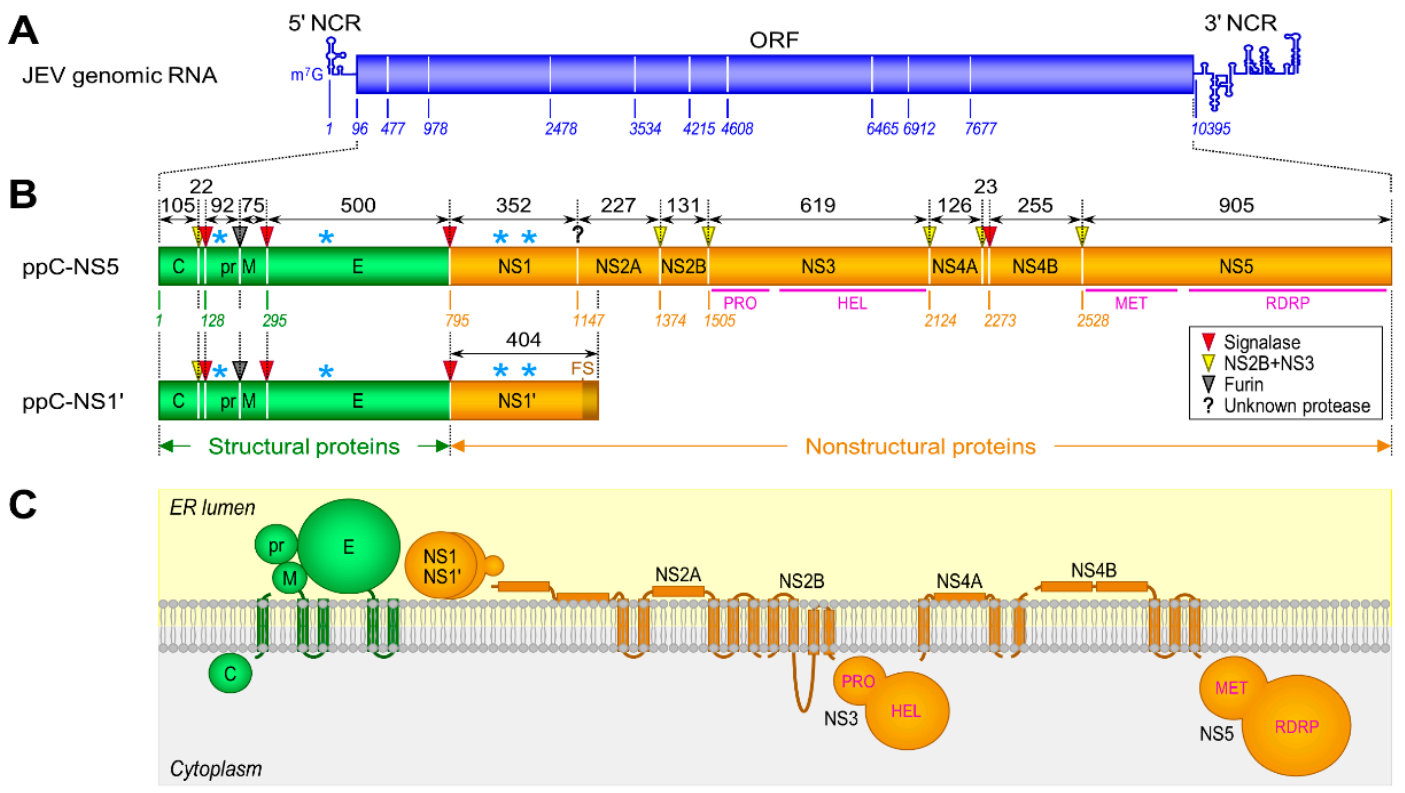

Figure 1. Genome organization and gene expression of Japanese encephalitis virus (JEV). (A) Genome organization. The genetically well-characterized JEV strain, CNU/LP2, contains a single-stranded positive-sense RNA genome of 10,968 nucleotides in length, consisting of a methylated cap at the $5^{\prime}$ end, followed by a 95-nucleotide $5^{\prime}$ non-coding region ( $\left.5^{\prime} \mathrm{NCR}\right)$, a 10,299-nucleotide open reading frame (ORF), and a 574-nucleotide $3^{\prime} \mathrm{NCR}[164,165]$. (B) Gene expression. The single ORF encoded in the viral genome produces two precursor polyproteins, a full-length 3432-amino acid polyprotein (ppC-NS5) and its C-terminally truncated 1198-amino acid polyprotein (ppC-NS1'), the latter of which is expressed by a -1 ribosomal frameshift (FS) event that occurs between the codons 8 and 9 of NS2A, adding 52 extra amino acids to the C-terminus of NS1 (designated NS1'). Each of the two polyproteins is cleaved by host- and virus-encoded proteases to yield three structural (green) and at least seven nonstructural (orange) proteins. The flavivirus-conserved cleavage sites and the length of cleavage products are indicated. NS3 consists of an N-terminal serine protease (PRO) domain and a C-terminal RNA helicase (HEL) domain, and NS5 consists of an N-terminal methyltransferase (MET) domain and a C-terminal RNA-dependent RNA polymerase (RDRP) domain. Asterisks indicate four N-linked glycosylation sites (NXT/S) found in the pr portion of prM $\left(\mathrm{Asn}^{15}\right), \mathrm{E}\left(\mathrm{Asn}^{154}\right)$, and NS1/NS1' $\left(\mathrm{Asn}^{130}\right.$ and $\mathrm{Asn}^{207}$ ). (C) Polyprotein membrane topology. The membrane orientation of the 10 major JEV proteins is predicted on the endoplasmic reticulum (ER) membrane, based on previous work with other flaviviruses [142,166-169].

\subsection{Viral Replication Cycle}

JEV is a flavivirus containing an inner nucleocapsid [170], a disordered structure made of the genomic RNA and helix-rich C proteins [171-173]. The nucleocapsid is enclosed by a lipid bilayer, which is in turn encased in a well-organized outer protein shell composed of the membrane-anchored prM/M and E proteins [174-179]. Basically, JEV shares a common strategy for viral replication with other flaviviruses (Figure 2). Viral entry is a dynamic process, defined by a series of interactions between the virus and the host cell that starts with nonspecific binding of the viral glycoprotein $E$ to one or more cellular attachment factors on the cell surface [180-185]. This attachment step serves to concentrate the virions at the cell surface to facilitate the specific interaction of the viral E glycoprotein with a cellular entry factor(s) [186-188], directing the classical clathrin-dependent endocytosis [189-200] or non-classical clathrin-independent endocytosis pathways [201-206], presumably in a cell type-restricted fashion. Once inside the endosome, the viral E glycoprotein undergoes low pH-induced conformational changes [207-213], triggering the fusion of viral and host endosomal membranes [214-221]. Following membrane fusion, the genomic RNA is released into the cytoplasm, 
where it is translated into two precursor polyproteins (with or without a ribosomal frameshifting at the beginning of NS2A-coding region) that are cleaved to yield three structural (C, prM, and E) and at least seven nonstructural (NS1 to NS5) proteins, along with NS1' [141,142].

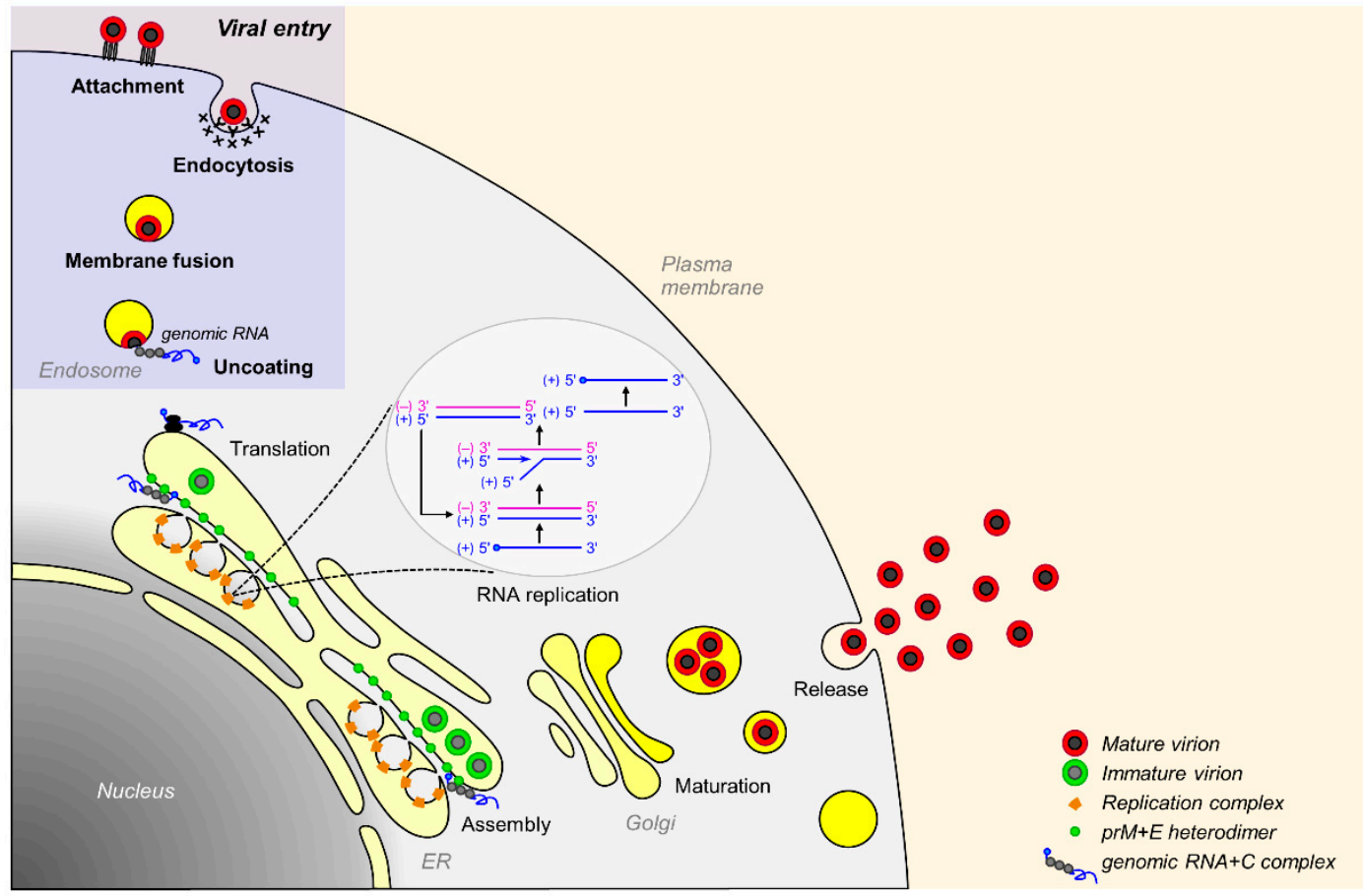

Figure 2. Replication cycle of JEV. A viral particle binds initially to a target cell through one or more attachment factors on the cell surface (Attachment). Subsequently, the virion interacts with an entry factor(s), which triggers receptor-mediated clathrin-dependent or clathrin-independent endocytosis of the bound virion (Endocytosis). Following internalization, the virion travels through the endosomal maturation pathway until endosomal acidification triggers the low $\mathrm{pH}$-induced activation of the viral E glycoprotein, enabling the fusion between viral and endosomal membranes (Membrane fusion). Upon release of the viral genomic RNA into the cytoplasm (Uncoating), it is translated into two overlapping polyproteins as the result of a -1 ribosomal frameshift event in association with the ER (Translation). The polyproteins are co- and post-translationally cleaved to generate the mature viral proteins that are essential for RNA replication and virion assembly. The genomic RNA is replicated in the replication complex within a structurally rearranged ER-derived membrane vesicles (RNA replication). Viral assembly proceeds with the concomitant interaction of viral RNA with the three structural proteins ( $\mathrm{C}$, prM, and E), promoting the budding of immature particles into the lumen of the ER (Assembly). The immature virions, containing heterodimers of prM and E, are then transported through the trans-Golgi network, where prM is cleaved to form mature virions containing homodimers of $\mathrm{M}$ and $\mathrm{E}$ (Maturation). Finally, both partially and completely mature virions are released into the extracellular milieu (Release).

After translation, all seven nonstructural proteins, together with the poorly understood host factors [222], are involved directly or indirectly in the genomic RNA replication that occurs in the virus-induced ER-derived membraneous organelle [223-227] housing the replication complexes [123,228]. Viral RNA replication is catalyzed by NS3 and NS5 [229], the two largest and most conserved nonstructural proteins that coordinate their multiple enzymatic activities in negative-strand RNA synthesis, positive-strand RNA synthesis, RNA capping, and cap methylation $[123,149,230]$. During or shortly after RNA replication, a complex of the newly synthesized genomic RNA and C proteins is enveloped by two viral glycoproteins (prM and E [231]) on the ER membrane to produce the immature virion ( $60 \mathrm{~nm}$ diameter) covered with 60 protruding spikes, each composed of three parallel prM:E 
heterodimers [232-235]. The immature virions are believed to pass through the constitutive secretory pathway to the extracellular space. During this exocytosis, viral maturation occurs in the trans-Golgi network through the furin-mediated cleavage of the prM protein to $M$ [156,236-238], accompanied by a significant structural rearrangement of the $\mathrm{M}$ and $\mathrm{E}$ proteins, to generate the mature virion ( $\sim 50 \mathrm{~nm}$ diameter), which is covered by 30 flat densely packed rafts, each composed of three parallel E:M:M:E heterotetramers $[232,239,240]$. In addition to the M-containing completely mature virions, prM-containing partially mature, but still infectious, virions are also shown to be produced [241-244], although viral infectivity is likely compromised [245]. Overall, viral replication takes place entirely in the cytoplasm; however, two viral proteins, C [246-250] and NS5 [251-257], are not only detected in the cytoplasm, but are also found in the nucleus [258]. The precise role of their nuclear localization in viral replication and pathogenesis requires further investigation.

\section{Viral Entry Is the First Step in the Infection Process}

Viral entry is the first step in an orchestrated process of virus-host interactions that is not only required for the initiation, dissemination, and maintenance of productive infection [259,260], but also represents a critical determinant of cell/tissue tropism and pathogenesis [261]. JEV entry is thus a promising target for antiviral therapy and offers multiple points for intervention [262]: attachment, endocytosis, membrane fusion, and uncoating (see a recent review article for a detailed description of small-molecule inhibitors targeting flavivirus entry [263]). Identifying the viral and host factors involved in JEV entry is a prerequisite to elucidating the molecular mechanisms of viral entry and developing novel therapeutic and preventive antivirals. In recent years, tremendous progress has been made in understanding the viral components required for the various steps of JEV entry, but little is known about the cellular components involved in this important process.

\subsection{Virus Structure}

Using cryo-electron microscopy (EM) and image reconstruction techniques, Wang and coworkers have determined the 4.3- $\AA$ three-dimensional structure of JEV [176]. On the surface of the mature JEV, 180 copies of each of the $\mathrm{M}$ and $\mathrm{E}$ proteins are organized into 30 flat, densely packed rafts. Each of these rafts is composed of three parallel E:M:M:E heterotetramers, with the E proteins forming the smooth outer protein shell and the M proteins being buried underneath it (Figure 3A), as seen in the cryo-EM structures initially of DENV [174,179] and WNV [175], and lately ZIKV [177,178]. The JEV E monomer, like that of other flavivirus E proteins, consists of three topologically distinct segments (Figure 3B,C): (i) a banana-shaped ectodomain, which mediates receptor binding and membrane fusion; (ii) a "stem" region, which includes three perimembrane helices lying nearly horizontal on the viral membrane underneath the ectodomain; and (iii) an "anchor" region, which contains two antiparallel membrane-embedded helices [240,264-266]. Notably, the E ectodomain adopts a three-domain architecture, with domain I (E-DI) lying at the interface between domains II (E-DII) and III (E-DIII) (Figure 3C): (a) E-DI has the glycan loop carrying an N-linked carbohydrate chain attached to $\mathrm{Asn}^{154}$ and a string of six closely dispersed basic residues ( Lys $^{279}$ to Lys ${ }^{297}$ ) mapped in the last strand $\mathrm{I}_{0}$ of E-DI and the linker between E-DI and DIII; (b) E-DII contains the fusion loop at its tip and several potentially functionally important loops (e.g., h-i, i-j, and k-l loops) on its side; and (c) E-DIII has the Arg-Gly-Asp (RGD) motif and is implicated in receptor binding and antibody neutralization [267-284]. In contrast, the JEV M monomer contains a flexible N-terminal loop, followed by an amphipathic helix lying on the membrane and two antiparallel helices embedded in the membrane (Figure 3C). The N-terminal loop of M participates in electrostatic and hydrophobic interactions with E-DI and E-DII, and the amphipathic helix of M is involved in hydrogen-bond interactions with E-DII (centered at $\mathrm{Gl}^{264}$ near helix $\alpha \mathrm{B}$ ) and the $\mathrm{N}$-terminus of a neighboring M. The E-DI, E-DIII, and the helical stem region of $\mathrm{E}$ are held together by charge interactions. 
A

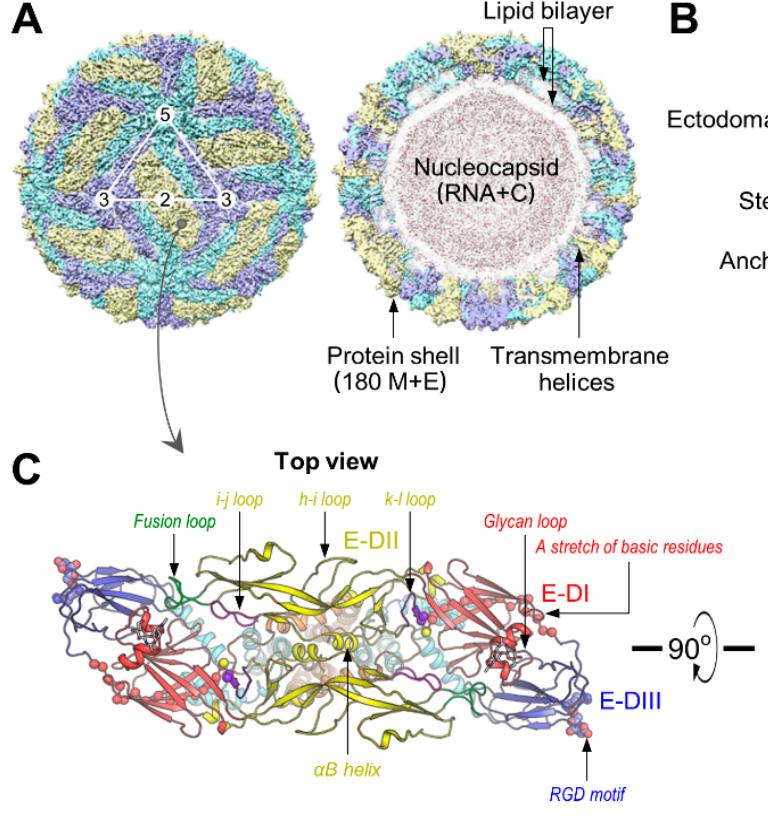

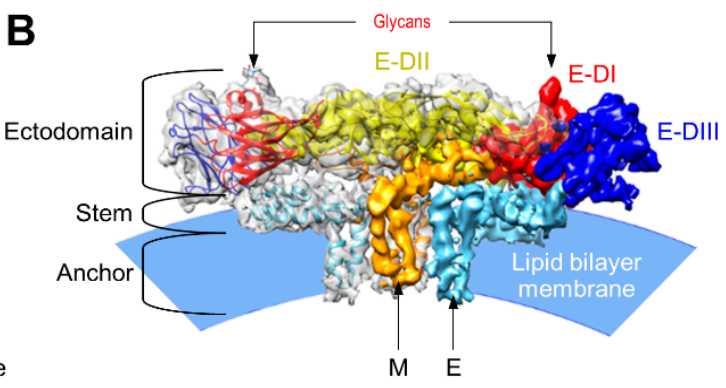

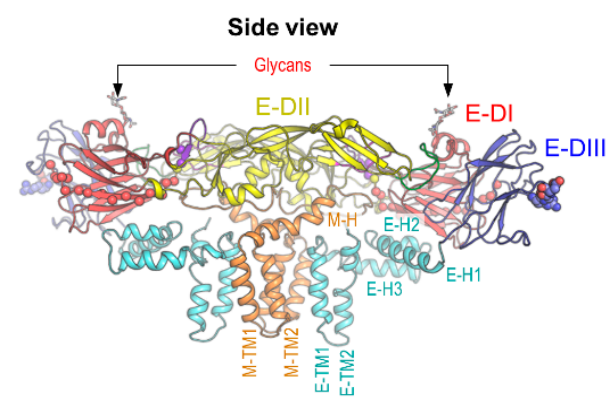

Figure 3. The cryo-electron microscopy (EM) structure of JEV at $4.3 \AA$ Aesolution. (A) The surface (left) and cross-section (right) of the cryo-EM map of mature JEV (strain P3). An icosahedral asymmetric unit is indicated by a white triangle, with the 2-, 3-, and 5-fold symmetry axes labeled. E:M heterodimers of the same color are equivalent by icosahedral symmetry. (B) Side view of the E:M heterodimer fitted into the electron density map. Indicated are the ectodomain, stem, and anchor regions of the E protein, along with the $\mathrm{M}$ protein buried underneath it. (C) Ribbon diagram of the E:M:M:E heterotetramer. Color-coded are the structurally distinct domains/regions of E and M proteins: E-DI (domain I), E-DII, E-DIII, E-H1 (helix 1), E-H2, E-H3, E-TM1 (transmembrane 1), E-TM2, M-H, M-TM1, and M-TM2. Also highlighted are the functionally important structural components in the E ectodomain: glycan loop and a stretch of basic residues in E-DI; fusion loop, h-i loop, i-j loop, k-1 loop, and $\alpha \mathrm{B}$ helx in E-DII; and Arg-Gly-Asp (RGD) motif in E-DIII. In all cases, one molecule is used for labeling. The high-resolution images of this figure were kindly provided by Dr. Xiangxi Wang [176].

\subsection{Attachment}

\subsubsection{Viral Components}

Despite recent advances in our understanding of the near-atomic resolution cryo-EM structure of JEV [176], the mechanisms by which the virion binds to its cellular receptors are not fully understood. In JEV [285-287] and other mosquito-borne flaviviruses [181-185,243,288-294], the presence of an N-linked glycan in E-DI (Figure 4A) and an RGD motif in E-DIII (Figure 4B) on the viral membrane suggests a mechanism of relatively nonspecific interactions with the carbohydrate-binding lectins and RGD-binding integrins on the cell surface, respectively; in agreement with this notion, blocking/alteration of either the $\mathrm{N}$-glycosylation or RGD motif generally negatively affects viral entry to varying degrees, but fails to abolish the process [182,243,285-295]. Also, a string of six closely dispersed basic residues ( Lys $^{279}$ to Lys ${ }^{297}$ ) located in the last strand $\mathrm{I}_{0}$ of E-DI and the linker between E-DI and E-DIII (Figure 4C), conserved among the members of the JE and DEN serogroups, has been proposed as a potential binding site for glycosaminoglycans (GAGs) [180,295]. However, the cryo-EM structure of JEV indicates that, of the six basic residues, four central residues are buried, suggesting that conformational changes are required to make this potential GAG-binding site accessible to GAGs [176]. Most intriguingly, the cryo-EM structure of JEV, combined with a structure-based amino acid sequence alignment of the E proteins from seven different flaviviruses (JEV, WNV, MVEV, SLEV, ZIKV, DENV, and YFV), reveals an unusual "hole" on the viral surface, with distinct electrostatic characteristics 
(Figure 4D) that could be a potential receptor-binding site for JEV and other members of the JE serogroup [176,296]. Thus, the viral components and their interacting cellular counterparts required for triggering flavivirus internalization after binding on the cell surface are still elusive.

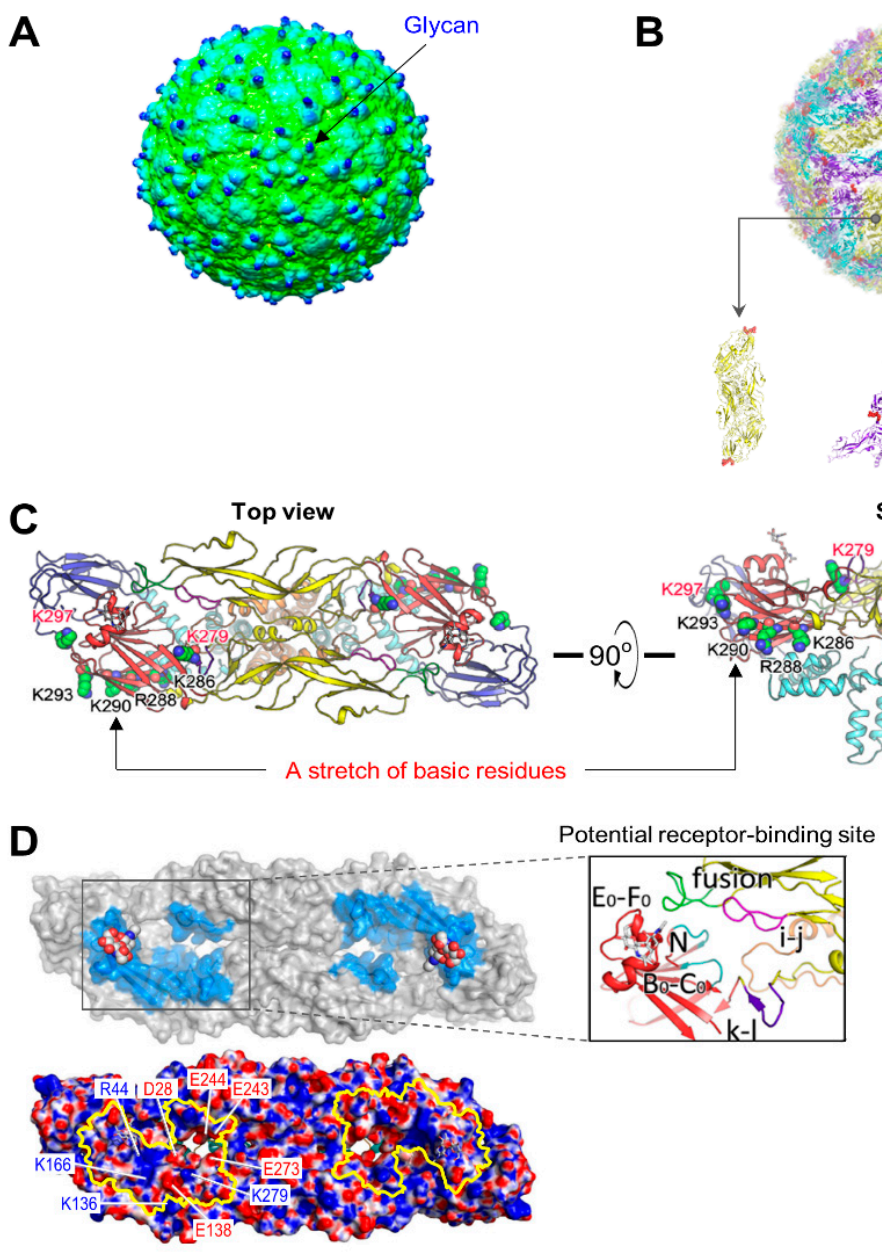

Figure 4. Location of the viral components involved in JEV entry on the protein shell of viral particles. (A) Location of glycans. The carbohydrate moieties attached to $\mathrm{Asn}^{154}$ are indicated on the surface of the cryo-EM map of JEV at a lower contour level. (B) Location of RGD motifs. RGD motifs are shown on the 2-, 3-, and 5-fold symmetry axes of the icosahedron. (C) Location of a basic residue-rich stretch in the E ectodomain. A cluster of six basic residues (Lys ${ }^{279}, \mathrm{Lys}^{286}, \mathrm{Arg}^{288}, \mathrm{Lys}^{290}, \mathrm{Lys}^{293}$, and $\mathrm{Lys}^{297}$ ) in the E ectodomain is shown on the top and side views of the atomic model of an E:M:M:E heterotetramer. The same color scheme as in Figure 3C is used, with the four resides (black) being buried inside the E ectodomain and the two resides (red) being exposed outside. (D) Location of putative receptor-binding sites. A pair of the charged residue-rich putative receptor-binding sites is highlighted in blue, with the glycans attached to Asn ${ }^{154}$ on the external surface of an E:M:M:E heterotetramer (top panel). The charged residues are indicated on the external electrostatic surface of the E:M:M:E heterotetramer, with the two putative receptor-binding sites outlined in yellow (bottom panel). An inset shows the molecular interactions formed in the putative receptor-binding site, involving the fusion and i-j loops that interact with the $\mathrm{N}$-terminal loop of the $\mathrm{A}_{0}$ strand (labeled as $\mathrm{N}$ ), the $\mathrm{B}_{0}-\mathrm{C}_{0}$ and $\mathrm{E}_{0}-\mathrm{F}_{0}$ loops in E-DI, and the k-l loop in E-DII from the opposite monomer. The images of this figure were graciously provided by Dr. Xiangxi Wang [176]. 


\subsubsection{Cellular Components}

JEV maintains a natural transmission cycle among birds, pigs, and other vertebrate hosts, with mosquito vectors; in vitro, JEV can infect and replicate in a broad range of cell types originating from many different vertebrate and invertebrate species [165], suggesting that there is probably more than one host factor responsible for viral entry. The host factors documented to be involved in the early steps of JEV entry to date are summarized in Table 1.

Table 1. Cellular components involved in the early steps of JEV entry.

\begin{tabular}{|c|c|c|c|}
\hline Cellular Component & Type/Property & Host Cell & Virus \\
\hline Heparan sulfate & Glycosaminoglycan & Mammal & JEV, WNV, MVEV, ZIKV, DENV, YFV, TBEV \\
\hline DC-SIGN/L-SIGN & C-type lectin & Mammal & JEV, WNV, DENV \\
\hline MR & C-type lectin & Mammal & JEV, DENV, TBEV \\
\hline CLEC5A & C-type lectin & Mammal & JEV, DENV \\
\hline LSECtin & C-type lectin & Mammal & JEV \\
\hline mosGCTL-7, 1 , and 3 & C-type lectin & Mosquito & JEV, WNV, DENV \\
\hline$\alpha_{\mathrm{v}} \beta_{3}$ & Integrin & Mammal & JEV, WNV \\
\hline HSP70/HSC70/GRP78 & 70-kDa heat shock protein & Mammal, Mosquito & JEV, DENV \\
\hline HSP90 & 90-kDa heat shock protein & Mammal & JEV, DENV \\
\hline 37/67-kDa LR & High-affinity laminin receptor & Mammal & JEV \\
\hline CD4 & Immunoglobulin superfamily & Mammal & JEV \\
\hline CD14 & Pattern recognition receptor & Mammal & JEV \\
\hline Vimentin & Type III intermediate filament & Mammal & JEV \\
\hline LDLR & Low-density lipoprotein receptor & Mammal & JEV \\
\hline 74-kDa protein & Not characterized & Mammal & JEV \\
\hline 53-kDa protein & Not characterized & Mosquito & JEV \\
\hline
\end{tabular}

Glycosaminoglycans (GAGs)

In JEV [297-300] as well as six other pathogenic flaviviruses [180,274,300-312], GAGs, a family of linear, polydisperse, sulfated polysaccharides [313] (such as the heparan sulfates found in all animal tissues), serve as one of the initial attachment factors for concentrating viral particles on the cell surface prior to the interaction with other molecules. Negatively charged sulfate groups on the GAGs can bind to a cluster of positively charged residues on the viral E glycoprotein [314]. In the case of JEV, a role for GAGs in viral attachment has been demonstrated by (i) competition for viral binding to hamster kidney-derived BHK-21 cells by highly sulfated GAGs, such as heparin and dextran sulfate; (ii) pretreatment of BHK-21 cells with sodium chlorate, a potent sulfation inhibitor; (iii) a comparison of the binding efficiency of the virus to the hamster ovary-derived wild-type $\mathrm{CHO}$ cell line and its mutants with defects in GAG biosynthesis; and (iv) the identification of single net-positive-charge amino acid changes (e.g., $\mathrm{E}^{49} \mathrm{~K}, \mathrm{E}^{138} \mathrm{~K}, \mathrm{E}^{306} \mathrm{~K}, \mathrm{D}^{389} \mathrm{G} / \mathrm{D}^{389} \mathrm{~N}$, and $\mathrm{E}^{390} \mathrm{G}$ ) in the E-DI or E-DIII region, with an enhanced binding capacity for GAGs [297-300,315]. Interestingly, most if not all cell culture-adapted JEVs, including a live-attenuated JE vaccine $\mathrm{SA}_{14}-14-2$ strain derived from its virulent parental $\mathrm{SA}_{14}$ strain, exhibit an increased ability to bind heparin, a highly sulfated GAG [274,300,315]. Similar results have also been observed for the live-attenuated YF vaccine 17D strain derived from its virulent parental Asibi strain [301]. Thus, an increased binding affinity for highly sulfated GAGs seems to be favorable for flavivirus growth in cell culture, and GAG-adapted flaviviruses tend to show attenuated phenotypes in vivo.

\section{C-Type Lectins}

One set of attachment factors involved in flavivirus entry is the family of C-type lectins, which are $\mathrm{Ca}^{2+}$-dependent glycan-binding proteins that recognize carbohydrate moieties on the surface of invading pathogens, act as the receptors for internalization, and deliver the pathogens to endosomes for antigen presentation, thereby activating host defense systems [316,317]. Of particular interest are (i) the dendritic cell-specific intercellular adhesion molecule (ICAM)-3-grabbing non-integrin (DC-SIGN, also called CD209 and CLEC4L [318,319]), which is highly expressed on subsets of dendritic cells (DCs) and macrophages; and (ii) the liver/lymph node-specific ICAM-3-grabbing non-integrin (L-SIGN, 
also known as CD209L, CLEC4M, and DC-SIGNR for "DC-SIGN-related" [320-322]), which is mainly expressed on endothelial cells in the liver and lymph nodes [323]. For JEV, siRNA knockdown and antibody blocking experiments, combined with the characterization of a DC-SIGN mutant defective in its internalization, have shown that DC-SIGN is important for viral binding to DCs that is mediated by an N-linked mannose-rich glycan at $\mathrm{Asn}^{154}$ on the viral E protein, but it is dispensable for subsequent internalization [287]. Similarly, for WNV [181,324] and DENV [182,184,325-329], both DC-SIGN and L-SIGN have been shown to promote infection via an interaction with an N-glycan(s) at Asn ${ }^{154}$ (for WNV) and at both $\mathrm{Asn}^{67}$ and $\mathrm{Asn}^{153}$ (for DENV) on the viral E protein.

Based on the work with WNV and DENV, the use of DC-SIGN and L-SIGN as attachment factors for flaviviruses varies, depending on the number and location of $\mathrm{N}$-glycosylation sites on the viral $\mathrm{E}$ protein $[182,183,324,325]$, as well as on the type of $\mathrm{N}$-glycans linked to these sites, which is determined by the cells used for virus production [181,324-326]. Although glycosylation profiles may vary in a given cell line, in general, the high-mannose $\mathrm{N}$-glycans on mosquito cell-produced virions are recognized well by both DC-SIGN and L-SIGN, whereas the complex N-glycans on mammalian cell-produced virions are preferentially recognized by L-SIGN. There is a further added level of complexity because "mosaic" partially mature flaviviruses contain a small, but detectable, amount of the glycosylated uncleaved prM proteins [330,331], with one to three potential N-glycosylation sites within the pr region [332] that may directly or indirectly contribute to the lectin-mediated attachment of flaviviruses to the cell surface [324-326]. Notably, the physiologically relevant functional importance of DC-SIGN in flavivirus replication and pathogenesis in humans is underlined by the association of a single nucleotide polymorphism (SNP) found in the promoter region of the DC-SIGN gene with a greater susceptibility to dengue hemorrhagic fever (SNP rs4804803 [333]) and severe forms of tick-borne encephalitis (SNP rs2287886 [334]) in certain subpopulations.

There are three other C-type lectins that have been suggested to participate in the early steps of JEV infection: mannose receptor (MR); C-type lectin domain family 5, member A (CLEC5A); and liver and lymph node sinusoidal endothelial cell C-type lectin (LSECtin) [286,335-337]. (1) MR is expressed on subsets of macrophages and DCs, as well as on nonvascular endothelium; it plays multiple important roles in clearing endogenous molecules, promoting antigen presentation, and modulating cellular activation and trafficking [338]. A study has shown that the extracellular region of MR binds broadly to mosquito cell-produced DENV particles and pointedly to mammalian cell-expressed DENV E ectodomains in a $\mathrm{Ca}^{2+}$-dependent manner; in addition, the cell surface expression of human MR in mouse embryo-derived 3T3 cells confers DENV binding, and anti-MR antibodies inhibit DENV infection in human macrophages [335]. The same study has also reported that the extracellular region of MR binds in enzyme-linked immunosorbent assays to formalin-inactivated JEV and TBEV, although the nature of this binding has not been characterized [335]. (2) CLEC5A is exclusively expressed on myeloid cells (e.g., macrophages and monocytes) and associates with a 12-kDa DNAX-activating protein (DAP12), an adaptor molecule that transduces intracellular signaling involved in innate immunity; thus, CLEC5A is also known as myeloid DAP12-associating lectin-1 (MDL-1) [339,340]. CLEC5A has been shown to interact directly with JEV [336] and DENV [337], albeit in a $\mathrm{Ca}^{2+}$-independent manner, and is capable of inducing DAP12 phosphorylation in macrophages. Unlike DC-SIGN and L-SIGN, the CLEC5A-JEV / DENV interaction does not promote viral infection, but rather stimulates the release of proinflammatory cytokines (e.g., TNF- $\alpha$ and MCP-1), thereby potentially contributing to the pathogenesis of virus-induced inflammatory diseases [336,337]. In the case of both JEV and DENV infection, the inflammation-associated viral pathogenesis and lethality in mice can be ameliorated by blocking the CLEC5A-JEV/DENV interaction with anti-CLEC5A antibodies [336,337]. (3) LSECtin (also known as CLEC4G) is expressed on myeloid cells, as well as on sinusoidal endothelial cells of the liver and lymph node; it mediates pathogen recognition, uptake, and internalization [317,341]. Using human B lymphocyte-derived Daudi cells that are non-susceptible to JEV infection, researchers have recently shown that the ectopic expression of LSECtin renders the cells susceptible to JEV infection. This infection can be inhibited by N-acetylglucosamine $\beta 1-2$ mannose (a target for LSECtin) but not by 
mannan (a target for DC-SIGN/L-SIGN) [286]; however, the underlying mechanism of LSECtin in JEV entry has not been fully defined.

In addition to the mammalian C-type lectins described above, a family of mosquito galactose-specific C-type lectins (mosGCTLs) has been reported to play a central role in the entry steps of JEV [342], WNV [343], and DENV [344] in their major Culex/Aedes mosquito vectors. The original work has shown that mosGCTL-1 (VectorBase accession no. AAEL000563) as a secreted form of mannose-binding lectin (MBL) binds to WNV in a viral E protein-mediated $\mathrm{Ca}^{2+}$-dependent manner and brings the mosGCTL-1-WNV complex to its cell surface receptor, mosquito protein tyrosine phosphatase-1 (mosPTP-1), thereby facilitating WNV entry both in vivo and in vitro [343]. The mosPTP-1 is a mosquito homolog of human CD45 that is expressed on all nucleated cells of hemopoietic origin [345] and is critical for thymocyte development and activation [346,347] through its interaction with human MBL [348]. Since CD45 is expressed on hematopoietic cells that are important for flavivirus pathogenesis and host immunity [349], it will be interesting to determine whether the human MBL-CD45 interaction can also mediate the entry of flaviviruses into human cells [350]. Moreover, mosquito blood-feeding experiments have demonstrated that WNV infection can be blocked in vivo with anti-mosGCTL-1 antibodies [343], suggesting a promising new approach to interrupt the life cycle of WNV in mosquito populations. Similarly, mosGCTL-7 (AAEL002524) and mosGCTL-3 (AAEL000535) have subsequently been shown to be able to mediate the mosquito cell entry of JEV and DENV, respectively [342,344]. For DENV infection, a genetic association of the exon 1 polymorphisms of the human MBL gene (MBL2) with dengue hemorrhagic fever has been suggested because variant alleles and haplotypes related to low production levels of MBL are associated with the severity of DENV-induced diseases [351]. Further investigation is required to elucidate the underlying mechanism behind the variation in the usage of specific mosGCTLs for particular flaviviruses, along with distinct mosPTPs, and the role of the mosGCTL-mosPTP pathway in flavivirus entry.

Integrins

Integrins are a family of cell surface receptors, each composed of two subunits ( $\alpha$ and $\beta$ ), that act as linkers between the extracellular matrix and the actin cytoskeleton, and play a critical role in the activation and homing of hematopoietic cells [352]. Biochemical and molecular studies have demonstrated that in monkey kidney-derived Vero or human cervical carcinoma HeLa cells, the lineage-2 Sarafend strain of WNV binds to $\alpha_{v} \beta_{3}$ integrin, and WNV infection is notably decreased by pretreatment with anti- $\alpha_{\mathrm{V}} \beta_{3}$ antibodies, competition with recombinant $\alpha_{\mathrm{V}}$ or $\beta_{3}$ protein, or siRNA knockdown of the $\beta_{3}$ subunit; however, somewhat unexpectedly, WNV infection is only marginally affected by pretreatment with synthetic RGD peptides, an inhibitor of integrin-ligand interactions [288,353]. It has also been noted that soluble $\alpha_{\mathrm{v}} \beta_{3}$ can block WNV infection of Vero cells in a dose-dependent manner, and the expression of $\alpha_{\mathrm{v}} \beta_{3}$ increases the susceptibility to WNV infection of hamster melanoma CS-1 cells lacking functional integrin [288]. In contrast, another study has shown that the lineage-1 NY385-99 strain of WNV can infect and replicate in mouse embryonic fibroblasts lacking functional $\alpha_{\mathrm{v}} \beta_{3}$ [354]. Therefore, the discrepancies in these studies suggest that the role of $\alpha_{\mathrm{v}} \beta_{3}$ in WNV entry is potentially strain-specific and/or cell type-dependent. Further investigation is needed to define a potential role of $\alpha_{\mathrm{v}} \beta_{3}$ in WNV infection [355]. As previously seen for WNV, pretreatment with anti- $\alpha_{v} \beta_{3}$ antibodies has been shown to inhibit JEV entry into Vero cells [288]. A potential role for $\alpha_{\mathrm{V}} \beta_{3}$ in JEV entry has also been proposed in hamster kidney-derived BHK-21 cells, based on shRNA-based gene silencing and antibody/peptide-based blocking experiments using anti- $\alpha_{\mathrm{V}} \beta_{3}$ antibodies and synthetic RGD peptides, although their inhibitory effects varied significantly [285].

\section{Other Host Factors}

Heat shock proteins (HSPs) were long believed to be cytoplasmic proteins, but their protein- and/or lipid-mediated association with intracellular and plasma membranes is now well documented [356]. To date, two families of HSPs have been proposed to participate in the early steps of JEV infection, 
possibly in a cell type-dependent manner: (i) three members of the HSP70 family, namely the prototype HSP70, heat shock cognate protein 70 (HSC70), and glucose-regulated protein 78 (GRP78, also referred to as BiP for "binding immunoglobulin protein"); and (ii) the prototype HSP90 of the HSP90 family [196,357-362]. The details are as follows: (1) HSC70 derived from Ae. albopictus C6/36 cells has been shown by co-immunoprecipitation experiments to bind to JEV [357]. In C6/36 cells, gene knockdown experiments have identified HSC70 isoform D, which is involved in the clathrin-mediated endocytosis of JEV [196]. (2) HSP70 derived from mouse neuronal Neuro-2a cells has been shown by virus overlay protein binding assays to interact with JEV; the interaction between HSP70 and the JEV E protein has been demonstrated by co-immunoprecipitation and immunoblotting [358]. Antibody blocking experiments using anti-HSP70 antibodies have produced a significant reduction in JEV entry into Neuro-2a cells [358]. (3) In human hepatoma Huh7 cells, the association of both HSP70 and JEV E proteins with cholesterol-rich lipid rafts on the cell surface has been shown to be critical for JEV infection [197,359]. In Huh7 cells, both antibody blocking and siRNA knockdown experiments have revealed that HSP70, but not HSC70 or GRP78, is crucial for the host cell entry of vesicular stomatitis virus-based pseudoviruses expressing JEV prM and E proteins [359]. (4) In Neuro-2a cells, however, a combination of biochemical, genetic, and molecular experiments has shown that GRP78, capable of interacting with JEV E-DIII, plays multiple roles in the entry and post-entry steps of JEV infection [360]. (5) HSP90 isoform HSP90 $\beta$, but not HSP90 $\alpha$, is co-localized and co-immunoprecipitated with JEV E proteins in hamster kidney-derived BHK-21 cells infected with JEV; HSP90 $\beta$ is also shown to be secreted into the culture supernatant from JEV-infected BHK-21 cells, presumably in association with released virus particles, promoting viral infectivity or the release of infectious particles [361]. Thus, all the data available to date suggest that several members of the HSP70 and HSP90 families have pivotal, isoform-specific, and differential roles in JEV entry, depending to some extent on the cell type, like those documented in DENV entry [363-370].

Several other host factors are thought to promote the infection of various cell types by JEV: (i) the 37/67-kDa high-affinity laminin receptor, CD4, and CD14 in mouse microglial BV-2 cells [362]; (ii) the type III intermediate filament vimentin in mouse neuroblastoma N18 and human neuroblastoma HTB-11 cells [371,372], as well as in porcine kidney PS cells [373]; (iii) the low-density lipoprotein receptor in hamster kidney-derived BHK-21 cells [374]; (iv) a 74-kDa protein in monkey kidney-derived Vero cells [375]; and (v) a 53-kDa protein in Ae. albopictus C6/36 cells [376]. However, the biological function and physiological role of these molecules in JEV entry remain to be defined. In addition, a handful of other cellular components have also been put forward as putative receptors for one or more of other mosquito-borne flaviviruses, such as WNV, ZIKV, DENV, and YFV: (a) the phosphatidylserine-recognizing TIM (TIM-1, -3, and -4) and TAM (TYRO3, AXL, and MER) family members [185,377-388], (b) the phosphatidylserine- and phosphatidylethanolamine-binding protein CD300a [389], (c) the tight junction component Claudin-1 [390,391], (d) the scavenger receptor class B type I coupled with apolipoprotein A-I [392], (e) the 37/67-kDa high-affinity laminin receptor [393,394], (f) CD14-associated molecules [395], (g) the carbohydrate $\beta$ - $N$-acetylglucosamine moiety of glycosphingolipids [396,397], (h) the natural killer cell-activating receptor, NKp44 [398], and (i) the mosquito cell-derived prohibitin [399] (see two recent review articles for a detailed description of these molecules $[186,400])$. Despite these research efforts discussed above, however, the cell surface receptors and other host factors required for directing JEV, or any other flavivirus, into the receptor-mediated endocytic pathway and low $\mathrm{pH}$-dependent membrane fusion are still unknown.

\subsection{Endocytosis}

JEV is internalized from the plasma membrane of host cells to an endosomal compartment via multiple endocytic routes in vitro [401], largely depending on the types of cell being infected: (i) the classical clathrin-dependent pathway observed in the mosquito-derived C6/36 [196], hamster kidney-derived BHK-21 [194], monkey kidney-derived Vero [198,201], porcine kidney-derived PK15 [195], and mouse neural stem-like C17.2 [197] cells; and (ii) the non-classical clathrin-independent 
pathway (e.g., caveolin-dependent pathway) observed in the human neuroblastoma SK-N-SH [202], mouse neuroblastoma Neuro-2a [201], and rat neuroblastoma B104 [203] cells. In almost all of these cell lines (BHK-21, Vero, PK15, C17.2, SK-N-SH, Neuro-2a, and B104), the depletion of cholesterol from the cell membrane with methyl- $\beta$-cyclodextrin reduces productive JEV infection [194,195,197,201-203], suggesting an important role for cholesterol and possibly cholesterol-rich lipid rafts in both clathrin-dependent and clathrin-independent endocytosis of JEV. Upon internalization, trafficking of the endocytosed vesicles containing JEV particles to early and recycling endosomes is demonstrated to be regulated by the two Rab GTPases, Rab5 and Rab11, for clathrin-dependent endocytosis in BHK-21 cells [194]. In the case of clathrin-independent endocytosis in Neuro-2a cells, JEV-carrying vesicles are transported to Rab5-positive early endosomes before the release of its genomic RNA into the cytosol, and this vesicle trafficking is shown to be mediated by the actin-myosin II machinery that is modulated by the major Rho GTPase RhoA [201]. Similarly, RhoA and Rac1 GTPase-mediated actin rearrangements are documented to be critical for caveolin-dependent endocytosis of JEV in SK-N-SH cells [202]. Considering the variations mentioned above, it is necessary to determine the main endocytic pathway co-opted by JEV for its entry into human neurons in the brain, which are the major target cells of JEV, and human monocytes and macrophages/DCs in the periphery, which are likely to be of importance in mediating neuroinvasion.

Among other flaviviruses, WNV is reported thus far to adopt the clathrin-mediated endocytic pathway for entry into C6/36 [190], Vero [191], and HeLa [402] cells. On the other hand, DENV is shown to be able to enter the cytosol via an endosomal compartment, not only predominantly by clathrin-dependent endocytosis (as described in C6/36 [189,192,403], Vero [205,206,404], BSC-1 [193], NIH3T3 [328], HeLa [193,402], A549 [404], Huh7 [199], HepG2 [200,405], and ECV304 [406] cells and human monocytes/immature DCs [328,407]) but also partially by clathrin-independent endocytosis (as described in Vero [204-206,404] and HepG2 [200] cells). It has been noted in Vero cells, however, that DENV can utilize both clathrin-dependent and clathrin-independent pathways for internalization, depending on the viral serotype, and the virus can be transported to a different endosomal compartment prior to membrane fusion, depending on the viral strain, even within the same serotype [205,404]. Moreover, the main endocytic route employed by DENV in Vero cells is reported to be altered from a clathrin-independent pathway for C6/36-grown virus to the clathrin-dependent pathway for Vero-adapted virus [206]. In the case of both DENV and WNV, numerous studies have indicated the functional importance of cholesterol [204,354,408], cytoskeleton and motor proteins [189-192,199,328,409,410], and Rab GTPase-regulated vesicle trafficking [193,199,204,205, $328,402]$ in the process of their entry into various cell lines.

As is true for DENV, YFV is also able to enter HeLa cells via two distinct endocytic routes, as demonstrated by the finding that the wild-type virulent Asibi strain primarily utilizes the clathrin-dependent pathway, whereas its attenuated vaccine 17D strain exploits a pathway independent of both clathrin and caveolin [411]. A mutagenetic analysis has indicated that the strain-specific use of distinct endocytic pathways for YFV internalization is due to the 12 amino acid differences found within the viral E protein between Asibi and 17D [411]. Interestingly, the 17D vaccine strain is shown to enter HeLa and several other human cells more efficiently than does the parental Asibi strain, resulting in a stronger induction of the cytokine-mediated antiviral response [411]. These data suggest a potential link between viral entry and the host immune response. It will be interesting to examine whether the strain-specific use of different endocytic pathways for YFV internalization is maintained by an isogenic pair of JEV SA 14 and $\mathrm{SA}_{14}-14-2$ strains. In summary, JEV and other flaviviruses enter a wide range of different host cells by viral $\mathrm{E}$ protein-directed endocytosis, but the precise endocytic pathway used for viral internalization is determined by a combination of both the genetic composition of the viral E protein and the availability of its interacting cellular components in a given cell type.

In cell biology, clathrin-mediated endocytosis is one of the best-studied processes, with a network of various cellular proteins well characterized to date [412]. These previously known host factors are generally required for those viruses that usurp the clathrin-mediated endocytic pathway [381,413-418]. 
In addition, the interferon-inducible glycosylphosphatidylinositol-anchored lymphocyte antigen $6 \mathrm{E}$ (LY6E) has been found to play a role in facilitating YFV and WNV infection [415,419]. A recent study has shown that LY6E is required for the clathrin-mediated uptake of several mosquito-borne flaviviruses (WNV, ZIKV, and DENV) and of transferrin-coated particles that are similar in size to these virions, but not of free transferrins [420]. Cell biological studies have revealed that the internalization of these virions and transferrin-coated particles is triggered by the formation of tubule-like structures of LY6E, which depend on the vacuolar ATPase-associated transmembrane protein RNASEK (for "ribonuclease kappa") and microtubules [420-422]. It will be interesting to test whether this LY6E-mediated size-dependent endocytic pathway is also involved in the clathrin-mediated uptake of JEV. Furthermore, a genome-wide siRNA screen has identified the human G protein-coupled receptor kinase 2 (GRK2, also known as ADRBK1) as being involved in promoting both the entry and RNA replication steps of YFV and DENV [417]. Similar genomic screens using RNAi and CRISPR/Cas9 approaches have revealed a collection of human host factors that function at the early stages of DENV and ZIKV infection, of which the ER membrane protein complex (EMC) is suggested to play a role in a post-attachment step during viral entry [381]. Another large-scale RNAi screen has discovered a set of insect host factors and their human homologs that are required for DENV replication, with a subset presumably involved in viral entry [416]. Additional research is warranted to define the host factors selectively involved in the internalization process of JEV and other flaviviruses.

\subsection{Membrane Fusion and Uncoating}

As is true for other flaviviruses, JEV enters its host cells through clathrin-(in)dependent endocytosis and low pH-triggered membrane fusion, both of which are mediated by the viral glycoprotein E, a prototypical class II fusion protein [187,330,423-425]. In recent years, a working model of flavivirus membrane fusion has been established based on the dimeric pre-fusion and trimeric post-fusion E ectodomain crystal structures and biochemical properties of JEV [296,426], WNV [427,428], SLEV [429], ZIKV [430], DENV [210,211,240,431-433], and TBEV [208,278], together with reconstitution of in vitro transient fusion intermediates at different stages of the fusion process $[207,209,212-214,434]$. As illustrated in Figure 5, the fusion is initiated by a low pH-induced dissociation of the antiparallel E:M:M:E heterotetramers, followed by the exposure of the hydrophobic fusion loop of each E protein, its insertion only partway into the outer bilayer leaflet of the host cell membrane, and a large-scale structural rearrangement of the antiparallel E:E homodimer of the E:M:M:E heterotetramers into a parallel E:E:E homotrimer [330,423,425,435]; however, the fate of the antiparallel M:M homodimers is unknown. In the post-fusion E:E:E homotrimer, E-DIII folds back against the central trimer, presumably with the helical stem extended from the C-terminus of E-DIII along E-DII and toward the fusion loop (known as "zipping") [264,265,436-441]. During this E-DIII fold-back process, the overall structures of E-DI, E-DII, and E-DIII are maintained, but the relative orientations of the three domains are rearranged. To date, the steps involved in the $\mathrm{pH}$-induced domain rearrangement and their underlying mechanisms are not completely understood.

It is conceivable that cellular proteins may assist in bringing to completion the low $\mathrm{pH}$-initiated membrane fusion and discharge of the viral nucleocapsid/genome into the cytoplasm, but they have not yet been explored extensively. Earlier, a human genome-wide siRNA screen identified a collection of host proteins involved in the early steps of WNV infection; one of these proteins, ubiquitin ligase CBLL1 (Cbl-like protein 1, also known as Hakai), in conjunction with the ubiquitin-proteasome system (UPS), has been suggested to play a critical role in a post-attachment step of WNV entry, such as internalization [415]. The UPS has also been implicated in JEV entry, especially in a post-attachment step prior to the initial translation of viral genomic RNA [443]. Interestingly, biochemical assays, combined with live-cell imaging and single-particle tracking, have shown that in some flaviviruses (JEV and YFV), the virus-host cell membrane fusion is a distinct event that precedes the microtubule-mediated release of viral nucleocapsid/genome into the cytoplasm [444]. Even more intriguingly, a recent molecular 
biology-based study has demonstrated that during DENV entry, the release of viral genome or uncoating of viral nucleocapsid is hampered by inhibiting ubiquitination [445]. In the same study, viral capsid was shown to be degraded after internalization by the host UPS, although this event was not required to release the viral genomic RNA into the cytoplasm for initial translation [445]. On the other hand, another study has reported that the siRNA-based knockdown of CBLL1 expression has no significant effect on the infection efficiency of several mosquito-borne flaviviruses (WNV, DENV, and YFV) in human cells, and that treatment with proteasome inhibitors (MG132 and lactacystin) has no measurable impact on the entry of WNV [446]. Thus, further investigation is needed to determine the precise role of CBLL1 and UPS in the host-cell entry of JEV and other flaviviruses.

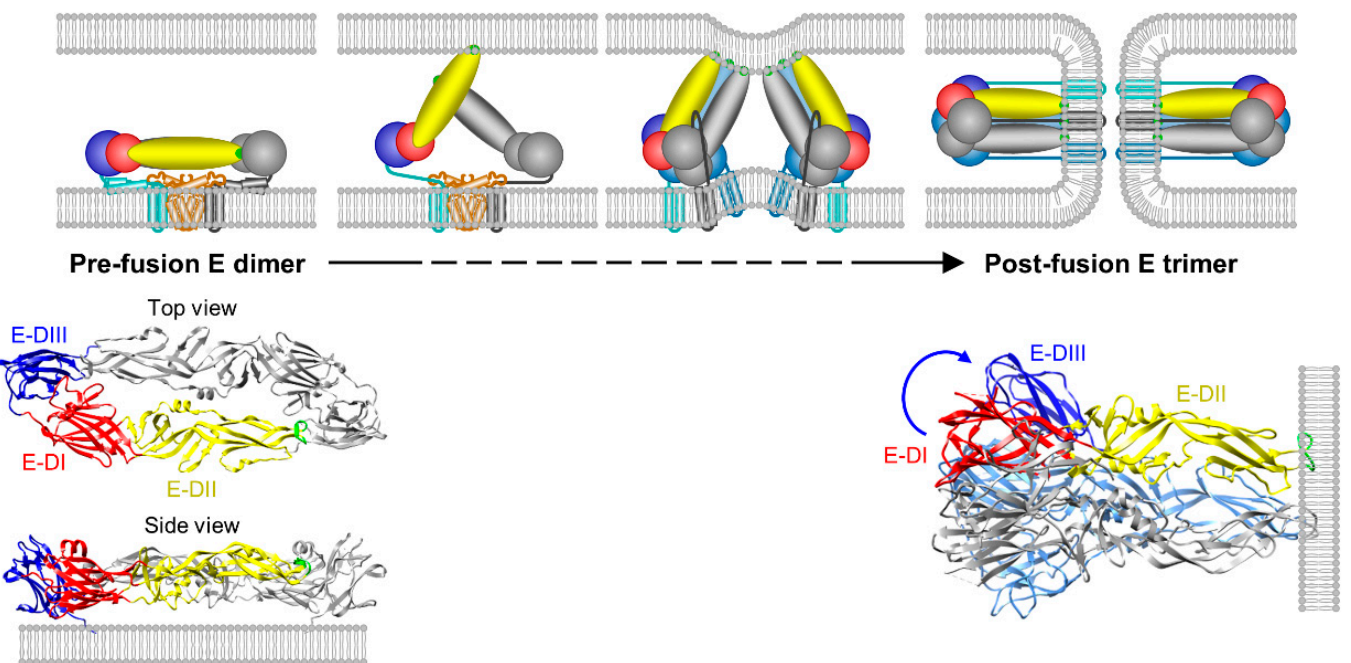

Figure 5. Schematic presentation illustrating JEV E-mediated membrane fusion. The membrane fusion event is initiated by the binding of a cellular receptor(s) to the viral pre-fusion E dimer of E:M:M:E heterotetramers, followed by dissociation of the E dimers, insertion of the fusion loops into the host cell membrane, trimerization of membrane-interacting E monomers, and changes in the $\mathrm{E}$ trimers to the post-fusion conformation. The diagram is modified from previously published work [442], with minor modification. Shown below the diagram are the pre-fusion E dimer of JEV (PDB 3P54) and the post-fusion E trimer of St. Louis encephalitis virus (SLEV, PDB 4FG0), a member of the JE serogroup.

\section{Conclusions: JEV Entry Is an Area of High Interest for Future Research}

Viral entry is the first step in an infection process that involves a cascade of multiple, highly coordinated interactions between the virus and its target cells. This aspect of virus research is of particular relevance because viral entry is a common feature essential to the initiation, dissemination, and maintenance of productive infection by all human and animal viruses. Whereas the viral factors involved in JEV entry are well defined (particularly viral glycoprotein E, which is involved in attachment, endocytosis, and membrane fusion), the host factors that participate in this multistep process remain poorly understood. To date, three types of multiple host factors (GAGs, C-type lectins, and integrins), along with their interacting counterparts (basic residue-rich region, glycan, and RGD motif, respectively) in the viral E glycoprotein, have been relatively well characterized as attachment factors for a range of mammalian and/or mosquito cells for promoting the cell entry of JEV and other flaviviruses, although they often act in a strain-specific and cell type-dependent manner. However, the host entry factor(s) that can direct receptor-mediated endocytosis and low $\mathrm{pH}$-dependent membrane fusion once viral attachment has occurred remain elusive. In particular, identification of the bona fide cell-surface receptor(s) responsible for JEV internalization has been a major challenge in JEV biology, primarily because of a lack of availability of the nonsusceptible cell line that has a block in JEV entry but can fully support the subsequent post-entry steps (translation, RNA replication, 
assembly, and release) and is therefore capable of serving as a platform cell line for receptor screening and validation. Over the years, only a few cell lines have been described to be resistant to JEV infection (e.g., human B lymphoblast Daudi [286] and mouse neuroblastoma N18TG2 [447]). With the use of such a JEV-nonsusceptible cell line, two complementary genome-wide genetic screens for both the gainand loss-of-function of JEV entry can allow us to identify the host factors that are critical for JEV entry and to dissect the discrete entry steps that are regulated by specific host factors. The outcomes of this research will not only shed new light on the cell/tissue tropism and pathogenesis of JEV, and possibly other closely related encephalitic flaviviruses, but also provide new targets for the development of novel antiviral interventions capable of inhibiting the early steps of JEV infection.

Author Contributions: S.-I.Y. and Y.-M.L. designed the review; both authors drafted and revised the final version of the manuscript.

Funding: This work was supported by the funds from Utah Science Technology and Research Initiative (A34637 and A35813). This work was also supported by the Utah Agricultural Experiment Station (UTAO-1345) at Utah State University and approved as journal paper number UAES \#9097.

Acknowledgments: We thank Xiangxi Wang (National Laboratory of Macromolecules, Institute of Biophysics, Chinese Academy of Science) for graciously providing a collection of high-resolution cryo-EM images of JEV. We also thank Deborah McClellan for her wonderful job of editing our manuscript.

Conflicts of Interest: The authors declare no conflict of interest.

\section{References}

1. Simmonds, P.; Becher, P.; Bukh, J.; Gould, E.A.; Meyers, G.; Monath, T.; Muerhoff, S.; Pletnev, A.; Rico-Hesse, R.; Smith, D.B.; et al. ICTV virus taxonomy profile: Flaviviridae. J. Gen. Virol. 2017, 98, 2-3. [CrossRef] [PubMed]

2. Simmonds, P.; Becher, P.; Collett, M.S.; Gould, E.A.; Heinz, F.X.; Meyers, G.; Monath, T.; Pletnev, A.; Rice, C.M.; Stiasny, K.; et al. Family flaviviridae. In Virus Taxonomy: 9th Report of the International Committee on Taxonomy of Viruses; King, A.M.Q., Adams, M.J., Carstens, E.B., Lefkowitz, E.J., Eds.; Elsevier Academic Press: San Diego, CA, USA, 2012.

3. Gould, E.A.; de Lamballerie, X.; Zanotto, P.M.; Holmes, E.C. Origins, evolution, and vector/host coadaptations within the genus Flavivirus. Adv. Virus Res. 2003, 59, 277-314. [PubMed]

4. Weaver, S.C.; Barrett, A.D. Transmission cycles, host range, evolution and emergence of arboviral disease. Nat. Rev. Microbiol. 2004, 2, 789-801. [CrossRef] [PubMed]

5. Valarcher, J.F.; Hagglund, S.; Juremalm, M.; Blomqvist, G.; Renstrom, L.; Zohari, S.; Leijon, M.; Chirico, J. Tick-borne encephalitis. Rev. Sci. Tech. 2015, 34, 453-466. [CrossRef] [PubMed]

6. Weissenbock, H.; Hubalek, Z.; Bakonyi, T.; Nowotny, N. Zoonotic mosquito-borne flaviviruses: Worldwide presence of agents with proven pathogenicity and potential candidates of future emerging diseases. Vet. Microbiol. 2010, 140, 271-280. [CrossRef] [PubMed]

7. Kuno, G.; Mackenzie, J.S.; Junglen, S.; Hubalek, Z.; Plyusnin, A.; Gubler, D.J. Vertebrate reservoirs of arboviruses: Myth, synonym of amplifier, or reality? Viruses 2017, 9, 185. [CrossRef] [PubMed]

8. Billoir, F.; de Chesse, R.; Tolou, H.; de Micco, P.; Gould, E.A.; de Lamballerie, X. Phylogeny of the genus Flavivirus using complete coding sequences of arthropod-borne viruses and viruses with no known vector. J. Gen. Virol. 2000, 81, 781-790. [CrossRef] [PubMed]

9. Alkan, C.; Zapata, S.; Bichaud, L.; Moureau, G.; Lemey, P.; Firth, A.E.; Gritsun, T.S.; Gould, E.A.; de Lamballerie, X.; Depaquit, J.; et al. Ecuador Paraiso Escondido virus, a new flavivirus isolated from New World sand flies in Ecuador, is the first representative of a novel clade in the genus Flavivirus. J. Virol. 2015, 89, 11773-11785. [CrossRef] [PubMed]

10. Blitvich, B.J.; Firth, A.E. A review of flaviviruses that have no known arthropod vector. Viruses 2017, 9, 154. [CrossRef] [PubMed]

11. Blitvich, B.J.; Firth, A.E. Insect-specific flaviviruses: A systematic review of their discovery, host range, mode of transmission, superinfection exclusion potential and genomic organization. Viruses 2015, 7, 1927-1959. [CrossRef] [PubMed] 
12. Bolling, B.G.; Weaver, S.C.; Tesh, R.B.; Vasilakis, N. Insect-specific virus discovery: Significance for the arbovirus community. Viruses 2015, 7, 4911-4928. [CrossRef] [PubMed]

13. Mackenzie, J.S.; Williams, D.T. The zoonotic flaviviruses of southern, south-eastern and eastern Asia, and Australasia: The potential for emergent viruses. Zoonoses Public Health 2009, 56, 338-356. [CrossRef] [PubMed]

14. Mackenzie, J.S.; Gubler, D.J.; Petersen, L.R. Emerging flaviviruses: The spread and resurgence of Japanese encephalitis, West Nile and dengue viruses. Nat. Med. 2004, 10, S98-S109. [CrossRef] [PubMed]

15. Sips, G.J.; Wilschut, J.; Smit, J.M. Neuroinvasive flavivirus infections. Rev. Med. Virol. 2012, 22, 69-87. [CrossRef] [PubMed]

16. Daep, C.A.; Munoz-Jordan, J.L.; Eugenin, E.A. Flaviviruses, an expanding threat in public health: Focus on dengue, West Nile, and Japanese encephalitis virus. J. Neurovirol. 2014, 20, 539-560. [CrossRef] [PubMed]

17. Mackenzie, J.S.; Barrett, A.D.; Deubel, V. The Japanese encephalitis serological group of flaviviruses: A brief introduction to the group. Curr. Top. Microbiol. Immunol. 2002, 267, 1-10. [PubMed]

18. Smith, D.R. Waiting in the wings: The potential of mosquito transmitted flaviviruses to emerge. Crit. Rev. Microbiol. 2017, 43, 405-422. [CrossRef] [PubMed]

19. Song, B.H.; Yun, S.I.; Woolley, M.; Lee, Y.M. Zika virus: History, epidemiology, transmission, and clinical presentation. J. Neuroimmunol. 2017, 308, 50-64. [CrossRef] [PubMed]

20. Vasilakis, N.; Weaver, S.C. The history and evolution of human dengue emergence. Adv. Virus Res. 2008, 72, 1-76. [PubMed]

21. Wasserman, S.; Tambyah, P.A.; Lim, P.L. Yellow fever cases in Asia: Primed for an epidemic. Int. J. Infect. Dis. 2016, 48, 98-103. [CrossRef] [PubMed]

22. Dobler, G. Zoonotic tick-borne flaviviruses. Vet. Microbiol. 2010, 140, 221-228. [CrossRef] [PubMed]

23. Solomon, T. Control of Japanese encephalitis-Within our grasp? N. Engl. J. Med. 2006, 355, 869-871. [CrossRef] [PubMed]

24. Misra, U.K.; Kalita, J. Overview: Japanese encephalitis. Prog. Neurobiol. 2010, 91, 108-120. [CrossRef] [PubMed]

25. Endy, T.P.; Nisalak, A. Japanese encephalitis virus: Ecology and epidemiology. Curr. Top. Microbiol. Immunol. 2002, 267, 11-48. [PubMed]

26. Erlanger, T.E.; Weiss, S.; Keiser, J.; Utzinger, J.; Wiedenmayer, K. Past, present, and future of Japanese encephalitis. Emerg. Infect. Dis. 2009, 15, 1-7. [CrossRef] [PubMed]

27. Mackenzie, J.S.; Williams, D.T.; Smith, D.W. Japanese encephalitis virus: The geographic distribution, incidence, and spread of a virus with a propensity to emerge in new areas. In Emerging Viruses in Human Populations; Tabor, E., Ed.; Elsevier: Amsterdam, The Netherlands, 2007.

28. Van den Hurk, A.F.; Ritchie, S.A.; Mackenzie, J.S. Ecology and geographical expansion of Japanese encephalitis virus. Annu. Rev. Entomol. 2009, 54, 17-35. [CrossRef] [PubMed]

29. Mackenzie, J.S.; Johansen, C.A.; Ritchie, S.A.; van den Hurk, A.F.; Hall, R.A. Japanese encephalitis as an emerging virus: The emergence and spread of Japanese encephalitis virus in Australasia. Curr. Top. Microbiol. Immunol. 2002, 267, 49-73. [PubMed]

30. Tiroumourougane, S.V.; Raghava, P.; Srinivasan, S. Japanese viral encephalitis. Postgrad. Med. J. 2002, 78, 205-215. [CrossRef] [PubMed]

31. World Health Organization (WHO). Japanese encephalitis vaccines. Wkly. Epidemiol. Rec. 2006, 81, 331-340.

32. Yun, S.I.; Lee, Y.M. Japanese encephalitis: The virus and vaccines. Hum. Vaccin. Immunother. 2014, 10, 263-279. [CrossRef] [PubMed]

33. Johansen, C.A.; van den Hurk, A.F.; Ritchie, S.A.; Zborowski, P.; Nisbet, D.J.; Paru, R.; Bockarie, M.J.; Macdonald, J.; Drew, A.C.; Khromykh, T.I.; et al. Isolation of Japanese encephalitis virus from mosquitoes (Diptera: Culicidae) collected in the Western Province of Papua New Guinea, 1997-1998. Am. J. Trop. Med. Hyg. 2000, 62, 631-638. [CrossRef] [PubMed]

34. Hanson, J.P.; Taylor, C.T.; Richards, A.R.; Smith, I.L.; Boutlis, C.S. Japanese encephalitis acquired near Port Moresby: Implications for residents and travellers to Papua New Guinea. Med. J. Aust. 2004, 181, 282-283. [PubMed]

35. Hanna, J.N.; Ritchie, S.A.; Phillips, D.A.; Lee, J.M.; Hills, S.L.; van den Hurk, A.F.; Pyke, A.T.; Johansen, C.A.; Mackenzie, J.S. Japanese encephalitis in north Queensland, Australia, 1998. Med. J. Aust. 1999, 170, 533-536. [PubMed] 
36. Hanna, J.N.; Ritchie, S.A.; Phillips, D.A.; Shield, J.; Bailey, M.C.; Mackenzie, J.S.; Poidinger, M.; McCall, B.J.; Mills, P.J. An outbreak of Japanese encephalitis in the Torres Strait, Australia, 1995. Med. J. Aust. 1996, 165, 256-260. [PubMed]

37. Ritchie, S.A.; Phillips, D.; Broom, A.; Mackenzie, J.; Poidinger, M.; van den Hurk, A. Isolation of Japanese encephalitis virus from Culex annulirostris in Australia. Am. J. Trop. Med. Hyg. 1997, 56, 80-84. [CrossRef] [PubMed]

38. Ritchie, S.A.; Rochester, W. Wind-blown mosquitoes and introduction of Japanese encephalitis into Australia. Emerg. Infect. Dis. 2001, 7, 900-903. [CrossRef] [PubMed]

39. Van den Hurk, A.F.; Montgomery, B.L.; Northill, J.A.; Smith, I.L.; Zborowski, P.; Ritchie, S.A.; Mackenzie, J.S.; Smith, G.A. Short report: The first isolation of Japanese encephalitis virus from mosquitoes collected from mainland Australia. Am. J. Trop. Med. Hyg. 2006, 75, 21-25. [PubMed]

40. Van den Hurk, A.F.; Ritchie, S.A.; Johansen, C.A.; Mackenzie, J.S.; Smith, G.A. Domestic pigs and Japanese encephalitis virus infection, Australia. Emerg. Infect. Dis. 2008, 14, 1736-1738. [CrossRef] [PubMed]

41. Paul, W.S.; Moore, P.S.; Karabatsos, N.; Flood, S.P.; Yamada, S.; Jackson, T.; Tsai, T.F. Outbreak of Japanese encephalitis on the island of Saipan, 1990. J. Infect. Dis. 1993, 167, 1053-1058. [CrossRef] [PubMed]

42. Igarashi, A.; Tanaka, M.; Morita, K.; Takasu, T.; Ahmed, A.; Ahmed, A.; Akram, D.S.; Waqar, M.A. Detection of West Nile and Japanese encephalitis viral genome sequences in cerebrospinal fluid from acute encephalitis cases in Karachi, Pakistan. Microbiol. Immunol. 1994, 38, 827-830. [CrossRef] [PubMed]

43. Li, M.H.; Fu, S.H.; Chen, W.X.; Wang, H.Y.; Guo, Y.H.; Liu, Q.Y.; Li, Y.X.; Luo, H.M.; Da, W.; Duo Ji, D.Z.; et al. Genotype V Japanese encephalitis virus is emerging. PLoS Negl. Trop. Dis. 2011, 5. [CrossRef] [PubMed]

44. Li, Y.X.; Li, M.H.; Fu, S.H.; Chen, W.X.; Liu, Q.Y.; Zhang, H.L.; Da, W.; Hu, S.L.; Mu, S.D.; Bai, J.; et al. Japanese encephalitis, Tibet, China. Emerg. Infect. Dis. 2011, 17, 934-936. [CrossRef] [PubMed]

45. Ravanini, P.; Huhtamo, E.; Ilaria, V.; Crobu, M.G.; Nicosia, A.M.; Servino, L.; Rivasi, F.; Allegrini, S.; Miglio, U.; Magri, A.; et al. Japanese encephalitis virus RNA detected in Culex pipiens mosquitoes in Italy. Euro Surveill 2012, 17. [CrossRef]

46. Platonov, A.; Rossi, G.; Karan, L.; Mironov, K.; Busani, L.; Rezza, G. Does the Japanese encephalitis virus (JEV) represent a threat for human health in Europe? Detection of JEV RNA sequences in birds collected in Italy. Euro Surveill 2012, 17. [CrossRef]

47. Zeller, H. Is Japanese encephalitis emerging in Europe? Euro Surveill 2012, 17. [CrossRef]

48. Nett, R.J.; Campbell, G.L.; Reisen, W.K. Potential for the emergence of Japanese encephalitis virus in California. Vector Borne Zoonotic Dis. 2009, 9, 511-517. [CrossRef] [PubMed]

49. Scherer, W.F.; Buescher, E.L.; Flemings, M.B.; Noguchi, A.; Scanlon, J. Ecologic studies of Japanese encephalitis virus in Japan. III. Mosquito factors. Zootropism and vertical flight of Culex tritaeniorhynchus with observations on variations in collections from animal-baited traps in different habitats. Am. J. Trop. Med. Hyg. 1959, 8, 665-677. [CrossRef] [PubMed]

50. Su, C.L.; Yang, C.F.; Teng, H.J.; Lu, L.C.; Lin, C.; Tsai, K.H.; Chen, Y.Y.; Chen, L.Y.; Chang, S.F.; Shu, P.Y. Molecular epidemiology of Japanese encephalitis virus in mosquitoes in Taiwan during 2005-2012. PLoS Negl. Trop. Dis. 2014, 8. [CrossRef] [PubMed]

51. Gajanana, A.; Rajendran, R.; Samuel, P.P.; Thenmozhi, V.; Tsai, T.F.; Kimura-Kuroda, J.; Reuben, R. Japanese encephalitis in south Arcot district, Tamil Nadu, India: A three-year longitudinal study of vector abundance and infection frequency. J. Med. Entomol. 1997, 34, 651-659. [CrossRef] [PubMed]

52. Lindahl, J.F.; Stahl, K.; Chirico, J.; Boqvist, S.; Thu, H.T.; Magnusson, U. Circulation of Japanese encephalitis virus in pigs and mosquito vectors within Can Tho city, Vietnam. PLoS Negl. Trop. Dis. 2013, 7. [CrossRef] [PubMed]

53. Seo, H.J.; Kim, H.C.; Klein, T.A.; Ramey, A.M.; Lee, J.H.; Kyung, S.G.; Park, J.Y.; Cho, Y.S.; Cho, I.S.; Yeh, J.Y. Molecular detection and genotyping of Japanese encephalitis virus in mosquitoes during a 2010 outbreak in the Republic of Korea. PLoS ONE 2013, 8. [CrossRef] [PubMed]

54. Tao, Z.; Liu, G.; Wang, M.; Wang, H.; Lin, X.; Song, L.; Wang, S.; Wang, H.; Liu, X.; Cui, N.; et al. Molecular epidemiology of Japanese encephalitis virus in mosquitoes during an outbreak in China, 2013. Sci. Rep. 2014, 4. [CrossRef] [PubMed]

55. Hall-Mendelin, S.; Jansen, C.C.; Cheah, W.Y.; Montgomery, B.L.; Hall, R.A.; Ritchie, S.A.; Van den Hurk, A.F. Culex annulirostris (Diptera: Culicidae) host feeding patterns and Japanese encephalitis virus ecology in northern Australia. J. Med. Entomol. 2012, 49, 371-377. [CrossRef] [PubMed] 
56. Okuno, T.; Tseng, P.T.; Liu, S.Y.; Hsu, S.Y.; Huang, C.T. Rates of infection with Japanese encephalitis virus of two culicine species of mosquito in Taiwan. Bull. World Health Organ. 1971, 44, 599-604. [PubMed]

57. Detels, R.; Cross, J.H.; Huang, W.C.; Lien, J.C.; Chen, S. Japanese encephalitis virus in Northern Taiwan, 1969-1973. Am. J. Trop. Med. Hyg. 1976, 25, 477-485. [CrossRef] [PubMed]

58. Gingrich, J.B.; Nisalak, A.; Latendresse, J.R.; Sattabongkot, J.; Hoke, C.H.; Pomsdhit, J.; Chantalakana, C.; Satayaphanta, C.; Uechiewcharnkit, K.; Innis, B.L. Japanese encephalitis virus in Bangkok: Factors influencing vector infections in three suburban communities. J. Med. Entomol. 1992, 29, 436-444. [CrossRef] [PubMed]

59. Peiris, J.S.; Amerasinghe, F.P.; Arunagiri, C.K.; Perera, L.P.; Karunaratne, S.H.; Ratnayake, C.B.; Kulatilaka, T.A.; Abeysinghe, M.R. Japanese encephalitis in Sri Lanka: Comparison of vector and virus ecology in different agro-climatic areas. Trans. R. Soc. Trop. Med. Hyg. 1993, 87, 541-548. [CrossRef]

60. Vythilingam, I.; Oda, K.; Mahadevan, S.; Abdullah, G.; Thim, C.S.; Hong, C.C.; Vijayamalar, B.; Sinniah, M.; Igarashi, A. Abundance, parity, and Japanese encephalitis virus infection of mosquitoes (Diptera: Culicidae) in Sepang District, Malaysia. J. Med. Entomol. 1997, 34, 257-262. [CrossRef] [PubMed]

61. Gould, D.J.; Edelman, R.; Grossman, R.A.; Nisalak, A.; Sullivan, M.F. Study of Japanese encephalitis virus in Chiangmai Valley, Thailand. IV. Vector studies. Am. J. Epidemiol. 1974, 100, 49-56. [CrossRef] [PubMed]

62. Leake, C.J.; Ussery, M.A.; Nisalak, A.; Hoke, C.H.; Andre, R.G.; Burke, D.S. Virus isolations from mosquitoes collected during the 1982 Japanese encephalitis epidemic in northern Thailand. Trans. R. Soc. Trop. Med. Hyg. 1986, 80, 831-837. [CrossRef]

63. Reuben, R.; Thenmozhi, V.; Samuel, P.P.; Gajanana, A.; Mani, T.R. Mosquito blood feeding patterns as a factor in the epidemiology of Japanese encephalitis in southern India. Am. J. Trop. Med. Hyg. 1992, 46, 654-663. [CrossRef] [PubMed]

64. Kim, H.; Cha, G.W.; Jeong, Y.E.; Lee, W.G.; Chang, K.S.; Roh, J.Y.; Yang, S.C.; Park, M.Y.; Park, C.; Shin, E.H. Detection of Japanese encephalitis virus genotype $\mathrm{V}$ in Culex orientalis and Culex pipiens (Diptera: Culicidae) in Korea. PLoS ONE 2015, 10. [CrossRef] [PubMed]

65. Huber, K.; Jansen, S.; Leggewie, M.; Badusche, M.; Schmidt-Chanasit, J.; Becker, N.; Tannich, E.; Becker, S.C. Aedes japonicus japonicus (Diptera: Culicidae) from Germany have vector competence for Japanese encephalitis virus but are refractory to infection with West Nile virus. Parasitol. Res. 2014, 113, 3195-3199. [CrossRef] [PubMed]

66. Mackenzie-Impoinvil, L.; Impoinvil, D.E.; Galbraith, S.E.; Dillon, R.J.; Ranson, H.; Johnson, N.; Fooks, A.R.; Solomon, T.; Baylis, M. Evaluation of a temperate climate mosquito, Ochlerotatus detritus (=Aedes detritus), as a potential vector of Japanese encephalitis virus. Med. Vet. Entomol. 2015, 29, 1-9. [CrossRef] [PubMed]

67. De Wispelaere, M.; Despres, P.; Choumet, V. European Aedes albopictus and Culex pipiens are competent vectors for Japanese encephalitis virus. PLoS Negl. Trop. Dis. 2017, 11. [CrossRef] [PubMed]

68. Weng, M.H.; Lien, J.C.; Wang, Y.M.; Wu, H.L.; Chin, C. Susceptibility of three laboratory strains of Aedes albopictus (Diptera: Culicidae) to Japanese encephalitis virus from Taiwan. J. Med. Entomol. 1997, 34, 745-747. [CrossRef] [PubMed]

69. Sucharit, S.; Surathin, K.; Shrestha, S.R. Vectors of Japanese encephalitis virus (JEV): Species complexes of the vectors. Southeast Asian J. Trop. Med. Public Health 1989, 20, 611-621. [PubMed]

70. Dhanda, V.; Mourya, D.T.; Mishra, A.C.; Ilkal, M.A.; Pant, U.; Jacob, P.G.; Bhat, H.R. Japanese encephalitis virus infection in mosquitoes reared from field-collected immatures and in wild-caught males. Am. J. Trop. Med. Hyg. 1989, 41, 732-736. [CrossRef] [PubMed]

71. Rosen, L.; Lien, J.C.; Shroyer, D.A.; Baker, R.H.; Lu, L.C. Experimental vertical transmission of Japanese encephalitis virus by Culex tritaeniorhynchus and other mosquitoes. Am. J. Trop. Med. Hyg. 1989, 40, 548-556. [CrossRef] [PubMed]

72. Rosen, L.; Lien, J.C.; Lu, L.C. A longitudinal study of the prevalence of Japanese encephalitis virus in adult and larval Culex tritaeniorhynchus mosquitoes in northern Taiwan. Am. J. Trop. Med. Hyg. 1989, 40, 557-560. [CrossRef] [PubMed]

73. Rosen, L.; Tesh, R.B.; Lien, J.C.; Cross, J.H. Transovarial transmission of Japanese encephalitis virus by mosquitoes. Science 1978, 199, 909-911. [CrossRef] [PubMed]

74. Cheng, V.C.C.; Sridhar, S.; Wong, S.C.; Wong, S.C.Y.; Chan, J.F.W.; Yip, C.C.Y.; Chau, C.H.; Au, T.W.K.; Hwang, Y.Y.; Yau, C.S.W.; et al. Japanese encephalitis virus transmitted via blood transfusion, Hong Kong, China. Emerg. Infect. Dis. 2018, 24, 49-57. [CrossRef] [PubMed] 
75. Buescher, E.L.; Scherer, W.F.; Rosenberg, M.Z.; Gresser, I.; Hardy, J.L.; Bullock, H.R. Ecologic studies of Japanese encephalitis virus in Japan. II. Mosquito infection. Am. J. Trop. Med. Hyg. 1959, 8, 651-664. [CrossRef] [PubMed]

76. Buescher, E.L.; Scherer, W.F. Ecologic studies of Japanese encephalitis virus in Japan. IX. Epidemiologic correlations and conclusions. Am. J. Trop. Med. Hyg. 1959, 8, 719-722. [CrossRef] [PubMed]

77. Scherer, W.F.; Moyer, J.T.; Izumi, T.; Gresser, I.; Mc, C.J. Ecologic studies of Japanese encephalitis virus in Japan. VI. Swine infection. Am. J. Trop. Med. Hyg. 1959, 8, 698-706. [CrossRef] [PubMed]

78. Ilkal, M.A.; Prasanna, Y.; Jacob, P.G.; Geevarghese, G.; Banerjee, K. Experimental studies on the susceptibility of domestic pigs to West Nile virus followed by Japanese encephalitis virus infection and vice versa. Acta Virol. 1994, 38, 157-161. [PubMed]

79. Nemeth, N.; Bosco-Lauth, A.; Oesterle, P.; Kohler, D.; Bowen, R. North American birds as potential amplifying hosts of Japanese encephalitis virus. Am. J. Trop. Med. Hyg. 2012, 87, 760-767. [CrossRef] [PubMed]

80. Buescher, E.L.; Scherer, W.F.; Mc, C.H.; Moyer, J.T.; Rosenberg, M.Z.; Yoshii, M.; Okada, Y. Ecologic studies of Japanese encephalitis virus in Japan. IV. Avian infection. Am. J. Trop. Med. Hyg. 1959, 8, 678-688. [CrossRef] [PubMed]

81. Hale, J.H.; Lim, K.A.; Colless, D.H. Investigation of domestic pigs as a potential reservoir of Japanese B encephalitis virus on Singapore Island. Ann. Trop. Med. Parasitol. 1957, 51, 374-379. [CrossRef] [PubMed]

82. Pond, W.L.; Russ, S.B.; Lancaster, W.E.; Audy, J.R.; Smadel, J.E. Japanese encephalitis in Malaya. II. Distribution of neutralizing antibodies in man and animals. Am. J. Hyg. 1954, 59, 17-25. [PubMed]

83. Takashima, I.; Watanabe, T.; Ouchi, N.; Hashimoto, N. Ecological studies of Japanese encephalitis virus in Hokkaido: Interepidemic outbreaks of swine abortion and evidence for the virus to overwinter locally. Am. J. Trop. Med. Hyg. 1988, 38, 420-427. [CrossRef] [PubMed]

84. Shimizu, T.; Kawakami, Y.; Fukuhara, S.; Matumoto, M. Experimental stillbirth in pregnant swine infected with Japanese encephalitis virus. Jpn. J. Exp. Med. 1954, 24, 363-375. [PubMed]

85. Nah, J.J.; Yang, D.K.; Kim, H.H.; Song, J.Y. The present and future of veterinary vaccines for Japanese encephalitis in Korea. Clin. Exp. Vaccine Res. 2015, 4, 130-136. [CrossRef] [PubMed]

86. Hsu, S.T.; Chang, L.C.; Lin, S.Y.; Chuang, T.Y.; Ma, C.H.; Inoue, Y.K.; Okuno, T. The effect of vaccination with a live attenuated strain of Japanese encephalitis virus on stillbirths in swine in Taiwan. Bull. World Health Organ. 1972, 46, 465-471. [PubMed]

87. Sulkin, S.E.; Allen, R.; Miura, T.; Toyokawa, K. Studies of arthropod-borne virus infections in Chiroptera. VI. Isolation of Japanese B encephalitis virus from naturally infected bats. Am. J. Trop. Med. Hyg. 1970, 19, 77-87. [CrossRef] [PubMed]

88. Wang, J.L.; Pan, X.L.; Zhang, H.L.; Fu, S.H.; Wang, H.Y.; Tang, Q.; Wang, L.F.; Liang, G.D. Japanese encephalitis viruses from bats in Yunnan, China. Emerg. Infect. Dis. 2009, 15, 939-942. [CrossRef] [PubMed]

89. Van den Hurk, A.F.; Smith, C.S.; Field, H.E.; Smith, I.L.; Northill, J.A.; Taylor, C.T.; Jansen, C.C.; Smith, G.A.; Mackenzie, J.S. Transmission of Japanese encephalitis virus from the black flying fox, Pteropus alecto, to Culex annulirostris mosquitoes, despite the absence of detectable viremia. Am. J. Trop. Med. Hyg. 2009, 81, 457-462. [PubMed]

90. Miura, T.; Toyokawa, K.; Allen, R.; Sulkin, S.E. Studies of arthropod-borne virus infections in Chiroptera. VII. Serologic evidence of natural Japanese B encephalitis virus infection in bats. Am. J. Trop. Med. Hyg. 1970, 19, 88-93. [CrossRef] [PubMed]

91. Sulkin, S.E.; Allen, R.; Sims, R.; Singh, K.V. Studies of arthropod-borne virus infections in Chiroptera. IV. The immune response of the big brown bat (Eptesicus $f$. fuscus) maintained at various environmental temperatures to experimental Japanese B encephalitis virus infection. Am. J. Trop. Med. Hyg. 1966, 15, 418-427. [CrossRef] [PubMed]

92. La Motte, L.C., Jr. Japanese B encephalitis in bats during simulated hibernation. Am. J. Hyg. 1958, 67, 101-108. [PubMed]

93. Lam, K.H.; Ellis, T.M.; Williams, D.T.; Lunt, R.A.; Daniels, P.W.; Watkins, K.L.; Riggs, C.M. Japanese encephalitis in a racing thoroughbred gelding in Hong Kong. Vet. Rec. 2005, 157, 168-173. [CrossRef] [PubMed]

94. Nakamura, H. Japanese encephalitis in horses in Japan. Equine Vet. J. 1972, 4, 155-156. [CrossRef] [PubMed]

95. Sugiura, T.; Shimada, K. Seroepizootiological survey of Japanese encephalitis virus and Getah virus in regional horse race tracks from 1991 to 1997 in Japan. J. Vet. Med. Sci. 1999, 61, 877-881. [CrossRef] [PubMed] 
96. Yamanaka, T.; Tsujimura, K.; Kondo, T.; Yasuda, W.; Okada, A.; Noda, K.; Okumura, T.; Matsumura, T. Isolation and genetic analysis of Japanese encephalitis virus from a diseased horse in Japan. J. Vet. Med. Sci. 2006, 68, 293-295. [CrossRef] [PubMed]

97. Gould, D.J.; Byrne, R.J.; Hayes, D.E. Experimental infection of horses with Japanese encephalitis virus by mosquito bite. Am. J. Trop. Med. Hyg. 1964, 13, 742-746. [CrossRef] [PubMed]

98. Konishi, E.; Shoda, M.; Kondo, T. Analysis of yearly changes in levels of antibodies to Japanese encephalitis virus nonstructural 1 protein in racehorses in central Japan shows high levels of natural virus activity still exist. Vaccine 2006, 24, 516-524. [CrossRef] [PubMed]

99. Gulati, B.R.; Singha, H.; Singh, B.K.; Virmani, N.; Kumar, S.; Singh, R.K. Isolation and genetic characterization of Japanese encephalitis virus from equines in India. J. Vet. Sci. 2012, 13, 111-118. [CrossRef] [PubMed]

100. Kheng, C.S.; Chee, T.K.; Marchette, N.J.; Garcia, R.; Rudnick, A.; Coughlan, R.F. Japanese B encephalitis in a horse. Aust. Vet. J. 1968, 44, 23-25. [CrossRef]

101. Yang, D.K.; Kim, B.H.; Kweon, C.H.; Nah, J.J.; Kim, H.J.; Lee, K.W.; Yang, Y.J.; Mun, K.W. Serosurveillance for Japanese encephalitis, Akabane, and Aino viruses for Thoroughbred horses in Korea. J. Vet. Sci. 2008, 9 , 381-385. [CrossRef] [PubMed]

102. Katayama, T.; Saito, S.; Horiuchi, S.; Maruta, T.; Kato, T.; Yanase, T.; Yamakawa, M.; Shirafuji, H. Nonsuppurative encephalomyelitis in a calf in Japan and isolation of Japanese encephalitis virus genotype 1 from the affected calf. J. Clin. Microbiol. 2013, 51, 3448-3453. [CrossRef] [PubMed]

103. Kako, N.; Suzuki, S.; Sugie, N.; Kato, T.; Yanase, T.; Yamakawa, M.; Shirafuji, H. Japanese encephalitis in a 114-month-old cow: Pathological investigation of the affected cow and genetic characterization of Japanese encephalitis virus isolate. BMC Vet. Res. 2014, 10. [CrossRef] [PubMed]

104. Shimizu, T.; Mochizuki, H.; Sugawa, Y.; Okazaki, K.; Matumoto, M. Studies on Japanese encephalitis of cattle-1. Bovine encephalitis caused by natural infection with Japanese encephalitis virus. Natl. Inst. Anim. Health Q. 1951, 23, 111-118.

105. Shimizu, T.; Mochizuki, H.; Sugawa, Y.; Okazaki, K.; Matumoto, M. Studies on Japanese encephalitis of cattle-2. Experimental infection of calves with virus of Japanese encephalitis. Natl. Inst. Anim. Health Q. 1951, 23, 119-128.

106. Lim, S.I.; Kweon, C.H.; Tark, D.S.; Kim, S.H.; Yang, D.K. Sero-survey on Aino, Akabane, Chuzan, bovine ephemeral fever and Japanese encephalitis virus of cattle and swine in Korea. J. Vet. Sci. 2007, 8, 45-49. [CrossRef] [PubMed]

107. Ilkal, M.A.; Dhanda, V.; Rao, B.U.; George, S.; Mishra, A.C.; Prasanna, Y.; Gopalkrishna, S.; Pavri, K.M. Absence of viraemia in cattle after experimental infection with Japanese encephalitis virus. Trans. R. Soc. Trop. Med. Hyg. 1988, 82, 628-631. [CrossRef]

108. Mall, M.P.; Kumar, A.; Malik, S.V. Sero-positivity of domestic animals against Japanese encephalitis in Bareilly area, U.P. J. Commun. Dis. 1995, 27, 242-246. [PubMed]

109. Kalaiyarasu, S.; Mishra, N.; Khetan, R.K.; Singh, V.P. Serological evidence of widespread West Nile virus and Japanese encephalitis virus infection in native domestic ducks (Anas platyrhynchos var domesticus) in Kuttanad region, Kerala, India. Comp. Immunol. Microbiol. Infect. Dis. 2016, 48, 61-68. [CrossRef] [PubMed]

110. Dhanda, V.; Banerjee, K.; Deshmukh, P.K.; Ilkal, M.A. Experimental viraemia and transmission of Japanese encephalitis virus by mosquitoes in domestic ducks. Indian J. Med. Res. 1977, 66, 881-888. [PubMed]

111. Nidaira, M.; Taira, K.; Itokazu, K.; Kudaka, J.; Nakamura, M.; Ohno, A.; Takasaki, T. Survey of the antibody against Japanese encephalitis virus in Ryukyu wild boars (Sus scrofa riukiuanus) in Okinawa, Japan. Jpn. J. Infect. Dis. 2007, 60, 309-311. [PubMed]

112. Ohno, Y.; Sato, H.; Suzuki, K.; Yokoyama, M.; Uni, S.; Shibasaki, T.; Sashika, M.; Inokuma, H.; Kai, K.; Maeda, K. Detection of antibodies against Japanese encephalitis virus in raccoons, raccoon dogs and wild boars in Japan. J. Vet. Med. Sci. 2009, 71, 1035-1039. [CrossRef] [PubMed]

113. Hamano, M.; Lim, C.K.; Takagi, H.; Sawabe, K.; Kuwayama, M.; Kishi, N.; Kurane, I.; Takasaki, T. Detection of antibodies to Japanese encephalitis virus in the wild boars in Hiroshima prefecture, Japan. Epidemiol. Infect. 2007, 135, 974-977. [CrossRef] [PubMed]

114. Yang, D.K.; Kweon, C.H.; Kim, B.H.; Hwang, I.J.; Kang, M.I.; So, B.J.; Cho, K.O. The seroprevalence of Japanese encephalitis virus in goats raised in Korea. J. Vet. Sci. 2007, 8, 197-199. [CrossRef] [PubMed]

115. Mansfield, K.L.; Hernandez-Triana, L.M.; Banyard, A.C.; Fooks, A.R.; Johnson, N. Japanese encephalitis virus infection, diagnosis and control in domestic animals. Vet. Microbiol. 2017, 201, 85-92. [CrossRef] [PubMed] 
116. Cleton, N.B.; Bosco-Lauth, A.; Page, M.J.; Bowen, R.A. Age-related susceptibility to Japanese encephalitis virus in domestic ducklings and chicks. Am. J. Trop. Med. Hyg. 2014, 90, 242-246. [CrossRef] [PubMed]

117. Ricklin, M.E.; Garcia-Nicolas, O.; Brechbuhl, D.; Python, S.; Zumkehr, B.; Posthaus, H.; Oevermann, A.; Summerfield, A. Japanese encephalitis virus tropism in experimentally infected pigs. Vet. Res. 2016, 47. [CrossRef] [PubMed]

118. Ricklin, M.E.; Garcia-Nicolas, O.; Brechbuhl, D.; Python, S.; Zumkehr, B.; Nougairede, A.; Charrel, R.N.; Posthaus, H.; Oevermann, A.; Summerfield, A. Vector-free transmission and persistence of Japanese encephalitis virus in pigs. Nat. Commun. 2016, 7. [CrossRef] [PubMed]

119. Miller, R.H.; Masuoka, P.; Klein, T.A.; Kim, H.C.; Somer, T.; Grieco, J. Ecological niche modeling to estimate the distribution of Japanese encephalitis virus in Asia. PLoS Negl. Trop. Dis. 2012, 6. [CrossRef] [PubMed]

120. Le Flohic, G.; Porphyre, V.; Barbazan, P.; Gonzalez, J.P. Review of climate, landscape, and viral genetics as drivers of the Japanese encephalitis virus ecology. PLoS Negl. Trop. Dis. 2013, 7. [CrossRef] [PubMed]

121. Lord, J.S.; Gurley, E.S.; Pulliam, J.R. Rethinking Japanese encephalitis virus transmission: A framework for implicating host and vector species. PLoS Negl. Trop. Dis. 2015, 9. [CrossRef] [PubMed]

122. Dong, H.; Fink, K.; Zust, R.; Lim, S.P.; Qin, C.F.; Shi, P.Y. Flavivirus RNA methylation. J. Gen. Virol. 2014, 95, 763-778. [CrossRef] [PubMed]

123. Klema, V.J.; Padmanabhan, R.; Choi, K.H. Flaviviral replication complex: Coordination between RNA synthesis and 5'-RNA capping. Viruses 2015, 7, 4640-4656. [CrossRef] [PubMed]

124. Ray, D.; Shah, A.; Tilgner, M.; Guo, Y.; Zhao, Y.; Dong, H.; Deas, T.S.; Zhou, Y.; Li, H.; Shi, P.Y. West Nile virus $5^{\prime}$-cap structure is formed by sequential guanine N-7 and ribose 2 '-O methylations by nonstructural protein 5. J. Virol. 2006, 80, 8362-8370. [CrossRef] [PubMed]

125. Daffis, S.; Szretter, K.J.; Schriewer, J.; Li, J.; Youn, S.; Errett, J.; Lin, T.Y.; Schneller, S.; Zust, R.; Dong, H.; et al. 2'-O methylation of the viral mRNA cap evades host restriction by IFIT family members. Nature 2010, 468, 452-456. [CrossRef] [PubMed]

126. Zust, R.; Cervantes-Barragan, L.; Habjan, M.; Maier, R.; Neuman, B.W.; Ziebuhr, J.; Szretter, K.J.; Baker, S.C.; Barchet, W.; Diamond, M.S.; et al. Ribose 2'-O-methylation provides a molecular signature for the distinction of self and non-self mRNA dependent on the RNA sensor Mda5. Nat. Immunol. 2011, 12, 137-143. [CrossRef] [PubMed]

127. Yun, S.I.; Choi, Y.J.; Song, B.H.; Lee, Y.M. $3^{\prime}$ cis-acting elements that contribute to the competence and efficiency of Japanese encephalitis virus genome replication: Functional importance of sequence duplications, deletions, and substitutions. J. Virol. 2009, 83, 7909-7930. [CrossRef] [PubMed]

128. Song, B.H.; Yun, S.I.; Choi, Y.J.; Kim, J.M.; Lee, C.H.; Lee, Y.M. A complex RNA motif defined by three discontinuous 5-nucleotide-long strands is essential for flavivirus RNA replication. RNA 2008, 14, 1791-1813. [CrossRef] [PubMed]

129. Brinton, M.A.; Basu, M. Functions of the $3^{\prime}$ and $5^{\prime}$ genome RNA regions of members of the genus Flavivirus. Virus Res. 2015, 206, 108-119. [CrossRef] [PubMed]

130. Ng, W.C.; Soto-Acosta, R.; Bradrick, S.S.; Garcia-Blanco, M.A.; Ooi, E.E. The $5^{\prime}$ and $3^{\prime}$ untranslated regions of the flaviviral genome. Viruses 2017, 9, 137. [CrossRef] [PubMed]

131. Villordo, S.M.; Carballeda, J.M.; Filomatori, C.V.; Gamarnik, A.V. RNA structure duplications and flavivirus host adaptation. Trends Microbiol. 2016, 24, 270-283. [CrossRef] [PubMed]

132. Lin, K.C.; Chang, H.L.; Chang, R.Y. Accumulation of a $3^{\prime}$-terminal genome fragment in Japanese encephalitis virus-infected mammalian and mosquito cells. J. Virol. 2004, 78, 5133-5138. [CrossRef] [PubMed]

133. Pijlman, G.P.; Funk, A.; Kondratieva, N.; Leung, J.; Torres, S.; van der Aa, L.; Liu, W.J.; Palmenberg, A.C.; Shi, P.Y.; Hall, R.A.; et al. A highly structured, nuclease-resistant, noncoding RNA produced by flaviviruses is required for pathogenicity. Cell Host Microbe 2008, 4, 579-591. [CrossRef] [PubMed]

134. Silva, P.A.; Pereira, C.F.; Dalebout, T.J.; Spaan, W.J.; Bredenbeek, P.J. An RNA pseudoknot is required for production of yellow fever virus subgenomic RNA by the host nuclease XRN1. J. Virol. 2010, 84, 11395-11406. [CrossRef] [PubMed]

135. Funk, A.; Truong, K.; Nagasaki, T.; Torres, S.; Floden, N.; Balmori Melian, E.; Edmonds, J.; Dong, H.; Shi, P.Y.; Khromykh, A.A. RNA structures required for production of subgenomic flavivirus RNA. J. Virol. 2010, 84, 11407-11417. [CrossRef] [PubMed] 
136. Akiyama, B.M.; Laurence, H.M.; Massey, A.R.; Costantino, D.A.; Xie, X.; Yang, Y.; Shi, P.Y.; Nix, J.C.; Beckham, J.D.; Kieft, J.S. Zika virus produces noncoding RNAs using a multi-pseudoknot structure that confounds a cellular exonuclease. Science 2016, 354, 1148-1152. [CrossRef] [PubMed]

137. Moon, S.L.; Anderson, J.R.; Kumagai, Y.; Wilusz, C.J.; Akira, S.; Khromykh, A.A.; Wilusz, J. A noncoding RNA produced by arthropod-borne flaviviruses inhibits the cellular exoribonuclease XRN1 and alters host mRNA stability. RNA 2012, 18, 2029-2040. [CrossRef] [PubMed]

138. Pijlman, G.P. Flavivirus RNAi suppression: Decoding non-coding RNA. Curr. Opin. Virol. 2014, 7, 55-60. [CrossRef] [PubMed]

139. Clarke, B.D.; Roby, J.A.; Slonchak, A.; Khromykh, A.A. Functional non-coding RNAs derived from the flavivirus 3' untranslated region. Virus Res. 2015, 206, 53-61. [CrossRef] [PubMed]

140. Charley, P.A.; Wilusz, J. Standing your ground to exoribonucleases: Function of flavivirus long non-coding RNAs. Virus Res. 2016, 212, 70-77. [CrossRef] [PubMed]

141. Kim, J.K.; Kim, J.M.; Song, B.H.; Yun, S.I.; Yun, G.N.; Byun, S.J.; Lee, Y.M. Profiling of viral proteins expressed from the genomic RNA of Japanese encephalitis virus using a panel of 15 region-specific polyclonal rabbit antisera: Implications for viral gene expression. PLoS ONE 2015, 10. [CrossRef] [PubMed]

142. Lindenbach, B.D.; Murray, C.L.; Thiel, H.J.; Rice, C.M. Flaviviridae. In Fields Virology; Knipe, D.M., Howley, P.M., Cohen, J.I., Griffin, D.E., Lamb, R.A., Martin, M.A., Racaniello, V.R., Roizman, B., Eds.; Wolters Kluwer Health: Philadelphia, PA, USA, 2013.

143. Mason, P.W.; McAda, P.C.; Dalrymple, J.M.; Fournier, M.J.; Mason, T.L. Expression of Japanese encephalitis virus antigens in Escherichia coli. Virology 1987, 158, 361-372. [CrossRef]

144. Chambers, T.J.; McCourt, D.W.; Rice, C.M. Production of yellow fever virus proteins in infected cells: Identification of discrete polyprotein species and analysis of cleavage kinetics using region-specific polyclonal antisera. Virology 1990, 177, 159-174. [CrossRef]

145. Castle, E.; Nowak, T.; Leidner, U.; Wengler, G.; Wengler, G. Sequence analysis of the viral core protein and the membrane-associated proteins V1 and NV2 of the flavivirus West Nile virus and of the genome sequence for these proteins. Virology 1985, 145, 227-236. [CrossRef]

146. Wengler, G.; Castle, E.; Leidner, U.; Nowak, T.; Wengler, G. Sequence analysis of the membrane protein V3 of the flavivirus West Nile virus and of its gene. Virology 1985, 147, 264-274. [CrossRef]

147. Lobigs, M. Flavivirus premembrane protein cleavage and spike heterodimer secretion require the function of the viral proteinase NS3. Proc. Natl. Acad. Sci. USA 1993, 90, 6218-6222. [CrossRef] [PubMed]

148. Stocks, C.E.; Lobigs, M. Signal peptidase cleavage at the flavivirus C-prM junction: Dependence on the viral NS2B-3 protease for efficient processing requires determinants in C, the signal peptide, and prM. J. Virol. 1998, 72, 2141-2149. [PubMed]

149. Luo, D.; Vasudevan, S.G.; Lescar, J. The flavivirus NS2B-NS3 protease-helicase as a target for antiviral drug development. Antivir. Res. 2015, 118, 148-158. [CrossRef] [PubMed]

150. Castle, E.; Leidner, U.; Nowak, T.; Wengler, G.; Wengler, G. Primary structure of the West Nile flavivirus genome region coding for all nonstructural proteins. Virology 1986, 149, 10-26. [CrossRef]

151. Speight, G.; Coia, G.; Parker, M.D.; Westaway, E.G. Gene mapping and positive identification of the non-structural proteins NS2A, NS2B, NS3, NS4B and NS5 of the flavivirus Kunjin and their cleavage sites. J. Gen. Virol. 1988, 69, 23-34. [CrossRef] [PubMed]

152. Preugschat, F.; Strauss, J.H. Processing of nonstructural proteins NS4A and NS4B of dengue 2 virus In vitro and in vivo. Virology 1991, 185, 689-697. [CrossRef]

153. Lin, C.; Amberg, S.M.; Chambers, T.J.; Rice, C.M. Cleavage at a novel site in the NS4A region by the yellow fever virus NS2B-3 proteinase is a prerequisite for processing at the downstream 4A/4B signalase site. J. Virol. 1993, 67, 2327-2335. [PubMed]

154. Amberg, S.M.; Nestorowicz, A.; McCourt, D.W.; Rice, C.M. NS2B-3 proteinase-mediated processing in the yellow fever virus structural region: In vitro and in vivo studies. J. Virol. 1994, 68, 3794-3802. [PubMed]

155. Yamshchikov, V.F.; Compans, R.W. Processing of the intracellular form of the West Nile virus capsid protein by the viral NS2B-NS3 protease: An In vitro study. J. Virol. 1994, 68, 5765-5771. [PubMed]

156. Stadler, K.; Allison, S.L.; Schalich, J.; Heinz, F.X. Proteolytic activation of tick-borne encephalitis virus by furin. J. Virol. 1997, 71, 8475-8481. [PubMed] 
157. Falgout, B.; Chanock, R.; Lai, C.J. Proper processing of dengue virus nonstructural glycoprotein NS1 requires the N-terminal hydrophobic signal sequence and the downstream nonstructural protein NS2A. J. Virol. 1989, 63, 1852-1860. [PubMed]

158. Falgout, B.; Markoff, L. Evidence that flavivirus NS1-NS2A cleavage is mediated by a membrane-bound host protease in the endoplasmic reticulum. J. Virol. 1995, 69, 7232-7243. [PubMed]

159. Hori, H.; Lai, C.J. Cleavage of dengue virus NS1-NS2A requires an octapeptide sequence at the C terminus of NS1. J. Virol. 1990, 64, 4573-4577. [PubMed]

160. Firth, A.E.; Atkins, J.F. A conserved predicted pseudoknot in the NS2A-encoding sequence of West Nile and Japanese encephalitis flaviviruses suggests NS1' may derive from ribosomal frameshifting. Virol. J. 2009, 6. [CrossRef] [PubMed]

161. Melian, E.B.; Hinzman, E.; Nagasaki, T.; Firth, A.E.; Wills, N.M.; Nouwens, A.S.; Blitvich, B.J.; Leung, J.; Funk, A.; Atkins, J.F.; et al. NS1' of flaviviruses in the Japanese encephalitis virus serogroup is a product of ribosomal frameshifting and plays a role in viral neuroinvasiveness. J. Virol. 2010, 84, 1641-1647. [CrossRef] [PubMed]

162. Ye, Q.; Li, X.F.; Zhao, H.; Li, S.H.; Deng, Y.Q.; Cao, R.Y.; Song, K.Y.; Wang, H.J.; Hua, R.H.; Yu, Y.X.; et al. A single nucleotide mutation in NS2A of Japanese encephalitis-live vaccine virus (SA $14-14-2)$ ablates NS1' formation and contributes to attenuation. J. Gen. Virol. 2012, 93, 1959-1964. [CrossRef] [PubMed]

163. Yun, S.I.; Song, B.H.; Polejaeva, I.A.; Davies, C.J.; White, K.L.; Lee, Y.M. Comparison of the live-attenuated Japanese encephalitis vaccine $\mathrm{SA}_{14}-14-2$ strain with its pre-attenuated virulent parent $\mathrm{SA}_{14}$ strain: Similarities and differences In vitro and in vivo. J. Gen. Virol. 2016, 97, 2575-2591. [CrossRef] [PubMed]

164. Yun, S.I.; Kim, S.Y.; Choi, W.Y.; Nam, J.H.; Ju, Y.R.; Park, K.Y.; Cho, H.W.; Lee, Y.M. Molecular characterization of the full-length genome of the Japanese encephalitis viral strain K87P39. Virus Res. 2003, 96, 129-140. [CrossRef]

165. Yun, S.I.; Kim, S.Y.; Rice, C.M.; Lee, Y.M. Development and application of a reverse genetics system for Japanese encephalitis virus. J. Virol. 2003, 77, 6450-6465. [CrossRef] [PubMed]

166. Xie, X.; Gayen, S.; Kang, C.; Yuan, Z.; Shi, P.Y. Membrane topology and function of dengue virus NS2A protein. J. Virol. 2013, 87, 4609-4622. [CrossRef] [PubMed]

167. Li, Y.; Li, Q.; Wong, Y.L.; Liew, L.S.; Kang, C. Membrane topology of NS2B of dengue virus revealed by NMR spectroscopy. Biochim. Biophys. Acta 2015, 1848, 2244-2252. [CrossRef] [PubMed]

168. Zou, J.; Xie, X.; Wang, Q.Y.; Dong, H.; Lee, M.Y.; Kang, C.; Yuan, Z.; Shi, P.Y. Characterization of dengue virus NS4A and NS4B protein interaction. J. Virol. 2015, 89, 3455-3470. [CrossRef] [PubMed]

169. Miller, S.; Sparacio, S.; Bartenschlager, R. Subcellular localization and membrane topology of the dengue virus type 2 non-structural protein 4B. J. Biol. Chem. 2006, 281, 8854-8863. [CrossRef] [PubMed]

170. Oliveira, E.R.A.; Mohana-Borges, R.; de Alencastro, R.B.; Horta, B.A.C. The flavivirus capsid protein: Structure, function and perspectives towards drug design. Virus Res. 2017, 227, 115-123. [CrossRef] [PubMed]

171. Dokland, T.; Walsh, M.; Mackenzie, J.M.; Khromykh, A.A.; Ee, K.H.; Wang, S. West Nile virus core protein; tetramer structure and ribbon formation. Structure 2004, 12, 1157-1163. [CrossRef] [PubMed]

172. Ma, L.; Jones, C.T.; Groesch, T.D.; Kuhn, R.J.; Post, C.B. Solution structure of dengue virus capsid protein reveals another fold. Proc. Natl. Acad. Sci. USA 2004, 101, 3414-3419. [CrossRef] [PubMed]

173. Shang, Z.; Song, H.; Shi, Y.; Qi, J.; Gao, G.F. Crystal structure of the capsid protein from Zika virus. J. Mol. Biol. 2018, 430, 948-962. [CrossRef] [PubMed]

174. Kuhn, R.J.; Zhang, W.; Rossmann, M.G.; Pletnev, S.V.; Corver, J.; Lenches, E.; Jones, C.T.; Mukhopadhyay, S.; Chipman, P.R.; Strauss, E.G.; et al. Structure of dengue virus: Implications for flavivirus organization, maturation, and fusion. Cell 2002, 108, 717-725. [CrossRef]

175. Mukhopadhyay, S.; Kim, B.S.; Chipman, P.R.; Rossmann, M.G.; Kuhn, R.J. Structure of West Nile virus. Science 2003, 302. [CrossRef] [PubMed]

176. Wang, X.; Li, S.H.; Zhu, L.; Nian, Q.G.; Yuan, S.; Gao, Q.; Hu, Z.; Ye, Q.; Li, X.F.; Xie, D.Y.; et al. Near-atomic structure of Japanese encephalitis virus reveals critical determinants of virulence and stability. Nat. Commun. 2017, 8. [CrossRef] [PubMed]

177. Kostyuchenko, V.A.; Lim, E.X.; Zhang, S.; Fibriansah, G.; Ng, T.S.; Ooi, J.S.; Shi, J.; Lok, S.M. Structure of the thermally stable Zika virus. Nature 2016, 533, 425-428. [CrossRef] [PubMed] 
178. Sirohi, D.; Chen, Z.; Sun, L.; Klose, T.; Pierson, T.C.; Rossmann, M.G.; Kuhn, R.J. The 3.8 A resolution cryo-EM structure of Zika virus. Science 2016, 352, 467-470. [CrossRef] [PubMed]

179. Zhang, X.; Ge, P.; Yu, X.; Brannan, J.M.; Bi, G.; Zhang, Q.; Schein, S.; Zhou, Z.H. Cryo-EM structure of the mature dengue virus at 3.5-A resolution. Nat. Struct. Mol. Biol. 2013, 20, 105-110. [CrossRef] [PubMed]

180. Chen, Y.; Maguire, T.; Hileman, R.E.; Fromm, J.R.; Esko, J.D.; Linhardt, R.J.; Marks, R.M. Dengue virus infectivity depends on envelope protein binding to target cell heparan sulfate. Nat. Med. 1997, 3, 866-871. [CrossRef] [PubMed]

181. Davis, C.W.; Nguyen, H.Y.; Hanna, S.L.; Sanchez, M.D.; Doms, R.W.; Pierson, T.C. West Nile virus discriminates between DC-SIGN and DC-SIGNR for cellular attachment and infection. J. Virol. 2006, 80, 1290-1301. [CrossRef] [PubMed]

182. Navarro-Sanchez, E.; Altmeyer, R.; Amara, A.; Schwartz, O.; Fieschi, F.; Virelizier, J.L.; Arenzana-Seisdedos, F.; Despres, P. Dendritic-cell-specific ICAM3-grabbing non-integrin is essential for the productive infection of human dendritic cells by mosquito-cell-derived dengue viruses. EMBO Rep. 2003, 4, 723-728. [CrossRef] [PubMed]

183. Pokidysheva, E.; Zhang, Y.; Battisti, A.J.; Bator-Kelly, C.M.; Chipman, P.R.; Xiao, C.; Gregorio, G.G.; Hendrickson, W.A.; Kuhn, R.J.; Rossmann, M.G. Cryo-EM reconstruction of dengue virus in complex with the carbohydrate recognition domain of DC-SIGN. Cell 2006, 124, 485-493. [CrossRef] [PubMed]

184. Tassaneetrithep, B.; Burgess, T.H.; Granelli-Piperno, A.; Trumpfheller, C.; Finke, J.; Sun, W.; Eller, M.A.; Pattanapanyasat, K.; Sarasombath, S.; Birx, D.L.; et al. DC-SIGN (CD209) mediates dengue virus infection of human dendritic cells. J. Exp. Med. 2003, 197, 823-829. [CrossRef] [PubMed]

185. Hamel, R.; Dejarnac, O.; Wichit, S.; Ekchariyawat, P.; Neyret, A.; Luplertlop, N.; Perera-Lecoin, M.; Surasombatpattana, P.; Talignani, L.; Thomas, F.; et al. Biology of Zika virus infection in human skin cells. J. Virol. 2015, 89, 8880-8896. [CrossRef] [PubMed]

186. Perera-Lecoin, M.; Meertens, L.; Carnec, X.; Amara, A. Flavivirus entry receptors: An update. Viruses 2013, 6, 69-88. [CrossRef] [PubMed]

187. Pierson, T.C.; Kielian, M. Flaviviruses: Braking the entering. Curr. Opin. Virol. 2013, 3, 3-12. [CrossRef] [PubMed]

188. Nain, M.; Abdin, M.Z.; Kalia, M.; Vrati, S. Japanese encephalitis virus invasion of cell: Allies and alleys. Rev. Med. Virol. 2016, 26, 129-141. [CrossRef] [PubMed]

189. Acosta, E.G.; Castilla, V.; Damonte, E.B. Functional entry of dengue virus into Aedes albopictus mosquito cells is dependent on clathrin-mediated endocytosis. J. Gen. Virol. 2008, 89, 474-484. [CrossRef] [PubMed]

190. Chu, J.J.; Leong, P.W.; Ng, M.L. Analysis of the endocytic pathway mediating the infectious entry of mosquito-borne flavivirus West Nile into Aedes albopictus mosquito (C6/36) cells. Virology 2006, 349, 463-475. [CrossRef] [PubMed]

191. Chu, J.J.; Ng, M.L. Infectious entry of West Nile virus occurs through a clathrin-mediated endocytic pathway. J. Virol. 2004, 78, 10543-10555. [CrossRef] [PubMed]

192. Mosso, C.; Galvan-Mendoza, I.J.; Ludert, J.E.; del Angel, R.M. Endocytic pathway followed by dengue virus to infect the mosquito cell line C6/36 HT. Virology 2008, 378, 193-199. [CrossRef] [PubMed]

193. Van der Schaar, H.M.; Rust, M.J.; Chen, C.; van der Ende-Metselaar, H.; Wilschut, J.; Zhuang, X.; Smit, J.M. Dissecting the cell entry pathway of dengue virus by single-particle tracking in living cells. PLoS Pathog. 2008, 4. [CrossRef] [PubMed]

194. Liu, C.C.; Zhang, Y.N.; Li, Z.Y.; Hou, J.X.; Zhou, J.; Kan, L.; Zhou, B.; Chen, P.Y. Rab5 and Rab11 are required for clathrin-dependent endocytosis of Japanese encephalitis virus in BHK-21 cells. J. Virol. 2017, 91, e01113-e01117. [CrossRef] [PubMed]

195. Yang, S.; He, M.; Liu, X.; Li, X.; Fan, B.; Zhao, S. Japanese encephalitis virus infects porcine kidney epithelial PK15 cells via clathrin- and cholesterol-dependent endocytosis. Virol. J. 2013, 10. [CrossRef] [PubMed]

196. Chuang, C.K.; Yang, T.H.; Chen, T.H.; Yang, C.F.; Chen, W.J. Heat shock cognate protein 70 isoform D is required for clathrin-dependent endocytosis of Japanese encephalitis virus in C6/36 cells. J. Gen. Virol. 2015, 96, 793-803. [CrossRef] [PubMed]

197. Das, S.; Chakraborty, S.; Basu, A. Critical role of lipid rafts in virus entry and activation of phosphoinositide $3^{\prime}$ kinase/Akt signaling during early stages of Japanese encephalitis virus infection in neural stem/progenitor cells. J. Neurochem. 2010, 115, 537-549. [CrossRef] [PubMed] 
198. Nawa, M.; Takasaki, T.; Yamada, K.; Kurane, I.; Akatsuka, T. Interference in Japanese encephalitis virus infection of Vero cells by a cationic amphiphilic drug, chlorpromazine. J. Gen. Virol. 2003, 84, 1737-1741. [CrossRef] [PubMed]

199. Ang, F.; Wong, A.P.; Ng, M.M.; Chu, J.J. Small interference RNA profiling reveals the essential role of human membrane trafficking genes in mediating the infectious entry of dengue virus. Virol. J. 2010, 7. [CrossRef] [PubMed]

200. Suksanpaisan, L.; Susantad, T.; Smith, D.R. Characterization of dengue virus entry into HepG2 cells. J. Biomed. Sci. 2009, 16. [CrossRef] [PubMed]

201. Kalia, M.; Khasa, R.; Sharma, M.; Nain, M.; Vrati, S. Japanese encephalitis virus infects neuronal cells through a clathrin-independent endocytic mechanism. J. Virol. 2013, 87, 148-162. [CrossRef] [PubMed]

202. Xu, Q.; Cao, M.; Song, H.; Chen, S.; Qian, X.; Zhao, P.; Ren, H.; Tang, H.; Wang, Y.; Wei, Y.; et al. Caveolin-1-mediated Japanese encephalitis virus entry requires a two-step regulation of actin reorganization. Future Microbiol. 2016, 11, 1227-1248. [CrossRef] [PubMed]

203. Zhu, Y.Z.; Xu, Q.Q.; Wu, D.G.; Ren, H.; Zhao, P.; Lao, W.G.; Wang, Y.; Tao, Q.Y.; Qian, X.J.; Wei, Y.H.; et al. Japanese encephalitis virus enters rat neuroblastoma cells via a $\mathrm{pH}$-dependent, dynamin and caveola-mediated endocytosis pathway. J. Virol. 2012, 86, 13407-13422. [CrossRef] [PubMed]

204. Piccini, L.E.; Castilla, V.; Damonte, E.B. Dengue-3 virus entry into Vero cells: Role of clathrin-mediated endocytosis in the outcome of infection. PLOS ONE 2015, 10. [CrossRef] [PubMed]

205. Acosta, E.G.; Castilla, V.; Damonte, E.B. Differential requirements in endocytic trafficking for penetration of dengue virus. PLoS ONE 2012, 7. [CrossRef] [PubMed]

206. Acosta, E.G.; Piccini, L.E.; Talarico, L.B.; Castilla, V.; Damonte, E.B. Changes in antiviral susceptibility to entry inhibitors and endocytic uptake of dengue-2 virus serially passaged in Vero or C6/36 cells. Virus Res. 2014, 184, 39-43. [CrossRef] [PubMed]

207. Allison, S.L.; Schalich, J.; Stiasny, K.; Mandl, C.W.; Kunz, C.; Heinz, F.X. Oligomeric rearrangement of tick-borne encephalitis virus envelope proteins induced by an acidic pH. J. Virol. 1995, 69, 695-700. [PubMed]

208. Bressanelli, S.; Stiasny, K.; Allison, S.L.; Stura, E.A.; Duquerroy, S.; Lescar, J.; Heinz, F.X.; Rey, F.A. Structure of a flavivirus envelope glycoprotein in its low-pH-induced membrane fusion conformation. EMBO J. 2004, 23, 728-738. [CrossRef] [PubMed]

209. Liao, M.; Sanchez-San Martin, C.; Zheng, A.; Kielian, M. In vitro reconstitution reveals key intermediate states of trimer formation by the dengue virus membrane fusion protein. J. Virol. 2010, 84, 5730-5740. [CrossRef] [PubMed]

210. Modis, Y.; Ogata, S.; Clements, D.; Harrison, S.C. Structure of the dengue virus envelope protein after membrane fusion. Nature 2004, 427, 313-319. [CrossRef] [PubMed]

211. Nayak, V.; Dessau, M.; Kucera, K.; Anthony, K.; Ledizet, M.; Modis, Y. Crystal structure of dengue virus type 1 envelope protein in the postfusion conformation and its implications for membrane fusion. J. Virol. 2009, 83, 4338-4344. [CrossRef] [PubMed]

212. Stiasny, K.; Allison, S.L.; Schalich, J.; Heinz, F.X. Membrane interactions of the tick-borne encephalitis virus fusion protein E at low pH. J. Virol. 2002, 76, 3784-3790. [CrossRef] [PubMed]

213. Stiasny, K.; Kossl, C.; Lepault, J.; Rey, F.A.; Heinz, F.X. Characterization of a structural intermediate of flavivirus membrane fusion. PLoS Pathog. 2007, 3. [CrossRef] [PubMed]

214. Corver, J.; Ortiz, A.; Allison, S.L.; Schalich, J.; Heinz, F.X.; Wilschut, J. Membrane fusion activity of tick-borne encephalitis virus and recombinant subviral particles in a liposomal model system. Virology 2000, 269, 37-46. [CrossRef] [PubMed]

215. Despres, P.; Frenkiel, M.P.; Deubel, V. Differences between cell membrane fusion activities of two dengue type-1 isolates reflect modifications of viral structure. Virology 1993, 196, 209-219. [CrossRef] [PubMed]

216. Gollins, S.W.; Porterfield, J.S. pH-dependent fusion between the flavivirus West Nile and liposomal model membranes. J. Gen. Virol. 1986, 67, 157-166. [CrossRef] [PubMed]

217. Guirakhoo, F.; Hunt, A.R.; Lewis, J.G.; Roehrig, J.T. Selection and partial characterization of dengue 2 virus mutants that induce fusion at elevated pH. Virology 1993, 194, 219-223. [CrossRef] [PubMed]

218. McMinn, P.C.; Weir, R.C.; Dalgarno, L. A mouse-attenuated envelope protein variant of Murray Valley encephalitis virus with altered fusion activity. J. Gen. Virol. 1996, 77, 2085-2088. [CrossRef] [PubMed]

219. Randolph, V.B.; Stollar, V. Low pH-induced cell fusion in flavivirus-infected Aedes albopictus cell cultures. J. Gen. Virol. 1990, 71, 1845-1850. [CrossRef] [PubMed] 
220. Stiasny, K.; Koessl, C.; Heinz, F.X. Involvement of lipids in different steps of the flavivirus fusion mechanism. J. Virol. 2003, 77, 7856-7862. [CrossRef] [PubMed]

221. Summers, P.L.; Cohen, W.H.; Ruiz, M.M.; Hase, T.; Eckels, K.H. Flaviviruses can mediate fusion from without in Aedes albopictus mosquito cell cultures. Virus Res. 1989, 12, 383-392. [CrossRef]

222. Fernandez-Garcia, M.D.; Mazzon, M.; Jacobs, M.; Amara, A. Pathogenesis of flavivirus infections: Using and abusing the host cell. Cell Host Microbe 2009, 5, 318-328. [CrossRef] [PubMed]

223. Gillespie, L.K.; Hoenen, A.; Morgan, G.; Mackenzie, J.M. The endoplasmic reticulum provides the membrane platform for biogenesis of the flavivirus replication complex. J. Virol. 2010, 84, 10438-10447. [CrossRef] [PubMed]

224. Hsu, N.Y.; Ilnytska, O.; Belov, G.; Santiana, M.; Chen, Y.H.; Takvorian, P.M.; Pau, C.; van der Schaar, H.; Kaushik-Basu, N.; Balla, T.; et al. Viral reorganization of the secretory pathway generates distinct organelles for RNA replication. Cell 2010, 141, 799-811. [CrossRef] [PubMed]

225. Welsch, S.; Miller, S.; Romero-Brey, I.; Merz, A.; Bleck, C.K.; Walther, P.; Fuller, S.D.; Antony, C.; Krijnse-Locker, J.; Bartenschlager, R. Composition and three-dimensional architecture of the dengue virus replication and assembly sites. Cell Host Microbe 2009, 5, 365-375. [CrossRef] [PubMed]

226. Neufeldt, C.J.; Cortese, M.; Acosta, E.G.; Bartenschlager, R. Rewiring cellular networks by members of the Flaviviridae family. Nat. Rev. Microbiol. 2018, 16, 125-142. [CrossRef] [PubMed]

227. Harak, C.; Lohmann, V. Ultrastructure of the replication sites of positive-strand RNA viruses. Virology 2015, 479-480, 418-433. [CrossRef] [PubMed]

228. Brand, C.; Bisaillon, M.; Geiss, B.J. Organization of the flavivirus RNA replicase complex. Wiley Interdiscip. Rev. RNA 2017, 8. [CrossRef] [PubMed]

229. Bollati, M.; Alvarez, K.; Assenberg, R.; Baronti, C.; Canard, B.; Cook, S.; Coutard, B.; Decroly, E.; de Lamballerie, X.; Gould, E.A.; et al. Structure and functionality in flavivirus NS-proteins: Perspectives for drug design. Antivir. Res. 2010, 87, 125-148. [CrossRef] [PubMed]

230. Selisko, B.; Wang, C.; Harris, E.; Canard, B. Regulation of flavivirus RNA synthesis and replication. Curr. Opin. Virol. 2014, 9, 74-83. [CrossRef] [PubMed]

231. Konishi, E.; Mason, P.W. Proper maturation of the Japanese encephalitis virus envelope glycoprotein requires cosynthesis with the premembrane protein. J. Virol. 1993, 67, 1672-1675. [PubMed]

232. Li, L.; Lok, S.M.; Yu, I.M.; Zhang, Y.; Kuhn, R.J.; Chen, J.; Rossmann, M.G. The flavivirus precursor membrane-envelope protein complex: Structure and maturation. Science 2008, 319, 1830-1834. [CrossRef] [PubMed]

233. Zhang, Y.; Corver, J.; Chipman, P.R.; Zhang, W.; Pletnev, S.V.; Sedlak, D.; Baker, T.S.; Strauss, J.H.; Kuhn, R.J.; Rossmann, M.G. Structures of immature flavivirus particles. EMBO J. 2003, 22, 2604-2613. [CrossRef] [PubMed]

234. Zhang, Y.; Kaufmann, B.; Chipman, P.R.; Kuhn, R.J.; Rossmann, M.G. Structure of immature West Nile virus. J. Virol. 2007, 81, 6141-6145. [CrossRef] [PubMed]

235. Lorenz, I.C.; Allison, S.L.; Heinz, F.X.; Helenius, A. Folding and dimerization of tick-borne encephalitis virus envelope proteins prM and $\mathrm{E}$ in the endoplasmic reticulum. J. Virol. 2002, 76, 5480-5491. [CrossRef] [PubMed]

236. Elshuber, S.; Allison, S.L.; Heinz, F.X.; Mandl, C.W. Cleavage of protein prM is necessary for infection of BHK-21 cells by tick-borne encephalitis virus. J. Gen. Virol. 2003, 84, 183-191. [CrossRef] [PubMed]

237. Guirakhoo, F.; Heinz, F.X.; Mandl, C.W.; Holzmann, H.; Kunz, C. Fusion activity of flaviviruses: Comparison of mature and immature (prM-containing) tick-borne encephalitis virions. J. Gen. Virol. 1991, 72, 1323-1329. [CrossRef] [PubMed]

238. Yu, I.M.; Holdaway, H.A.; Chipman, P.R.; Kuhn, R.J.; Rossmann, M.G.; Chen, J. Association of the pr peptides with dengue virus at acidic pH blocks membrane fusion. J. Virol. 2009, 83, 12101-12107. [CrossRef] [PubMed]

239. Yu, I.M.; Zhang, W.; Holdaway, H.A.; Li, L.; Kostyuchenko, V.A.; Chipman, P.R.; Kuhn, R.J.; Rossmann, M.G.; Chen, J. Structure of the immature dengue virus at low $\mathrm{pH}$ primes proteolytic maturation. Science 2008, 319, 1834-1837. [CrossRef] [PubMed]

240. Zhang, Y.; Zhang, W.; Ogata, S.; Clements, D.; Strauss, J.H.; Baker, T.S.; Kuhn, R.J.; Rossmann, M.G. Conformational changes of the flavivirus E glycoprotein. Structure 2004, 12, 1607-1618. [CrossRef] [PubMed] 
241. Mukherjee, S.; Dowd, K.A.; Manhart, C.J.; Ledgerwood, J.E.; Durbin, A.P.; Whitehead, S.S.; Pierson, T.C. Mechanism and significance of cell type-dependent neutralization of flaviviruses. J. Virol. 2014, 88, 7210-7220. [CrossRef] [PubMed]

242. Nelson, S.; Jost, C.A.; Xu, Q.; Ess, J.; Martin, J.E.; Oliphant, T.; Whitehead, S.S.; Durbin, A.P.; Graham, B.S.; Diamond, M.S.; et al. Maturation of West Nile virus modulates sensitivity to antibody-mediated neutralization. PLoS Pathog. 2008, 4. [CrossRef] [PubMed]

243. Goo, L.; DeMaso, C.R.; Pelc, R.S.; Ledgerwood, J.E.; Graham, B.S.; Kuhn, R.J.; Pierson, T.C. The Zika virus envelope protein glycan loop regulates virion antigenicity. Virology 2018, 515, 191-202. [CrossRef] [PubMed]

244. Mukherjee, S.; Lin, T.Y.; Dowd, K.A.; Manhart, C.J.; Pierson, T.C. The infectivity of prM-containing partially mature West Nile virus does not require the activity of cellular furin-like proteases. J. Virol. 2011, 85, 12067-12072. [CrossRef] [PubMed]

245. Hsieh, S.C.; Wu, Y.C.; Zou, G.; Nerurkar, V.R.; Shi, P.Y.; Wang, W.K. Highly conserved residues in the helical domain of dengue virus type 1 precursor membrane protein are involved in assembly, precursor membrane (prM) protein cleavage, and entry. J. Biol. Chem. 2014, 289, 33149-33160. [CrossRef] [PubMed]

246. Mori, Y.; Okabayashi, T.; Yamashita, T.; Zhao, Z.; Wakita, T.; Yasui, K.; Hasebe, F.; Tadano, M.; Konishi, E.; Moriishi, K.; et al. Nuclear localization of Japanese encephalitis virus core protein enhances viral replication. J. Virol. 2005, 79, 3448-3458. [CrossRef] [PubMed]

247. Sangiambut, S.; Keelapang, P.; Aaskov, J.; Puttikhunt, C.; Kasinrerk, W.; Malasit, P.; Sittisombut, N. Multiple regions in dengue virus capsid protein contribute to nuclear localization during virus infection. J. Gen. Virol. 2008, 89, 1254-1264. [CrossRef] [PubMed]

248. Netsawang, J.; Noisakran, S.; Puttikhunt, C.; Kasinrerk, W.; Wongwiwat, W.; Malasit, P.; Yenchitsomanus, P.T.; Limjindaporn, T. Nuclear localization of dengue virus capsid protein is required for DAXX interaction and apoptosis. Virus Res. 2010, 147, 275-283. [CrossRef] [PubMed]

249. Bhuvanakantham, R.; Cheong, Y.K.; Ng, M.L. West Nile virus capsid protein interaction with importin and HDM2 protein is regulated by protein kinase C-mediated phosphorylation. Microbes Infect. 2010, 12, 615-625. [CrossRef] [PubMed]

250. Bhuvanakantham, R.; Chong, M.K.; Ng, M.L. Specific interaction of capsid protein and importin- $\alpha / \beta$ influences West Nile virus production. Biochem. Biophys. Res. Commun. 2009, 389, 63-69. [CrossRef] [PubMed]

251. Uchil, P.D.; Kumar, A.V.; Satchidanandam, V. Nuclear localization of flavivirus RNA synthesis in infected cells. J. Virol. 2006, 80, 5451-5464. [CrossRef] [PubMed]

252. Buckley, A.; Gaidamovich, S.; Turchinskaya, A.; Gould, E.A. Monoclonal antibodies identify the NS5 yellow fever virus non-structural protein in the nuclei of infected cells. J. Gen. Virol. 1992, 73, 1125-1130. [CrossRef] [PubMed]

253. Forwood, J.K.; Brooks, A.; Briggs, L.J.; Xiao, C.Y.; Jans, D.A.; Vasudevan, S.G. The 37-amino-acid interdomain of dengue virus NS5 protein contains a functional NLS and inhibitory CK2 site. Biochem. Biophys. Res. Commun. 1999, 257, 731-737. [CrossRef] [PubMed]

254. Tay, M.Y.; Smith, K.; Ng, I.H.; Chan, K.W.; Zhao, Y.; Ooi, E.E.; Lescar, J.; Luo, D.; Jans, D.A.; Forwood, J.K.; et al. The C-terminal 18 amino acid region of dengue virus NS5 regulates its subcellular localization and contains a conserved arginine residue essential for infectious virus production. PLoS Pathog. 2016, 12. [CrossRef] [PubMed]

255. Kumar, A.; Buhler, S.; Selisko, B.; Davidson, A.; Mulder, K.; Canard, B.; Miller, S.; Bartenschlager, R. Nuclear localization of dengue virus nonstructural protein 5 does not strictly correlate with efficient viral RNA replication and inhibition of type I interferon signaling. J. Virol. 2013, 87, 4545-4557. [CrossRef] [PubMed]

256. Pryor, M.J.; Rawlinson, S.M.; Butcher, R.E.; Barton, C.L.; Waterhouse, T.A.; Vasudevan, S.G.; Bardin, P.G.; Wright, P.J.; Jans, D.A.; Davidson, A.D. Nuclear localization of dengue virus nonstructural protein 5 through its importin $\alpha / \beta$-recognized nuclear localization sequences is integral to viral infection. Traffic 2007, 8 , 795-807. [CrossRef] [PubMed]

257. Brooks, A.J.; Johansson, M.; John, A.V.; Xu, Y.; Jans, D.A.; Vasudevan, S.G. The interdomain region of dengue NS5 protein that binds to the viral helicase NS3 contains independently functional importin $\beta 1$ and importin $\alpha / \beta$-recognized nuclear localization signals. J. Biol. Chem. 2002, 277, 36399-36407. [CrossRef] [PubMed]

258. Lopez-Denman, A.J.; Mackenzie, J.M. The IMPORTance of the nucleus during flavivirus replication. Viruses 2017, 9, 14. [CrossRef] [PubMed] 
259. Marsh, M.; Helenius, A. Virus entry: Open sesame. Cell 2006, 124, 729-740. [CrossRef] [PubMed]

260. Smith, A.E.; Helenius, A. How viruses enter animal cells. Science 2004, 304, 237-242. [CrossRef] [PubMed]

261. Schweighardt, B.; Atwood, W.J. Virus receptors in the human central nervous system. J. Neurovirol. 2001, 7, 187-195. [PubMed]

262. Altmeyer, R. Virus attachment and entry offer numerous targets for antiviral therapy. Curr. Pharm. Des. 2004, 10, 3701-3712. [CrossRef] [PubMed]

263. Wang, Q.Y.; Shi, P.Y. Flavivirus entry inhibitors. ACS Infect. Dis. 2015, 1, 428-434. [CrossRef] [PubMed]

264. Allison, S.L.; Stiasny, K.; Stadler, K.; Mandl, C.W.; Heinz, F.X. Mapping of functional elements in the stem-anchor region of tick-borne encephalitis virus envelope protein E. J. Virol. 1999, 73, 5605-5612. [PubMed]

265. Stiasny, K.; Allison, S.L.; Marchler-Bauer, A.; Kunz, C.; Heinz, F.X. Structural requirements for low-pH-induced rearrangements in the envelope glycoprotein of tick-borne encephalitis virus. J. Virol. 1996, 70, 8142-8147. [PubMed]

266. Zhang, W.; Chipman, P.R.; Corver, J.; Johnson, P.R.; Zhang, Y.; Mukhopadhyay, S.; Baker, T.S.; Strauss, J.H.; Rossmann, M.G.; Kuhn, R.J. Visualization of membrane protein domains by cryo-electron microscopy of dengue virus. Nat. Struct. Biol. 2003, 10, 907-912. [CrossRef] [PubMed]

267. Allison, S.L.; Schalich, J.; Stiasny, K.; Mandl, C.W.; Heinz, F.X. Mutational evidence for an internal fusion peptide in flavivirus envelope protein E. J. Virol. 2001, 75, 4268-4275. [CrossRef] [PubMed]

268. Beasley, D.W.; Barrett, A.D. Identification of neutralizing epitopes within structural domain III of the West Nile virus envelope protein. J. Virol. 2002, 76, 13097-13100. [CrossRef] [PubMed]

269. Bhardwaj, S.; Holbrook, M.; Shope, R.E.; Barrett, A.D.; Watowich, S.J. Biophysical characterization and vector-specific antagonist activity of domain III of the tick-borne flavivirus envelope protein. J. Virol. 2001, 75, 4002-4007. [CrossRef] [PubMed]

270. Chu, J.J.; Rajamanonmani, R.; Li, J.; Bhuvanakantham, R.; Lescar, J.; Ng, M.L. Inhibition of West Nile virus entry by using a recombinant domain III from the envelope glycoprotein. J. Gen. Virol. 2005, 86, 405-412. [CrossRef] [PubMed]

271. Crill, W.D.; Roehrig, J.T. Monoclonal antibodies that bind to domain III of dengue virus E glycoprotein are the most efficient blockers of virus adsorption to Vero cells. J. Virol. 2001, 75, 7769-7773. [CrossRef] [PubMed]

272. Halstead, S.B.; Heinz, F.X.; Barrett, A.D.; Roehrig, J.T. Dengue virus: Molecular basis of cell entry and pathogenesis, 25-27 June 2003, Vienna, Austria. Vaccine 2005, 23, 849-856. [CrossRef] [PubMed]

273. Kaufmann, B.; Nybakken, G.E.; Chipman, P.R.; Zhang, W.; Diamond, M.S.; Fremont, D.H.; Kuhn, R.J.; Rossmann, M.G. West Nile virus in complex with the Fab fragment of a neutralizing monoclonal antibody. Proc. Natl. Acad. Sci. USA 2006, 103, 12400-12404. [CrossRef] [PubMed]

274. Lee, E.; Lobigs, M. Mechanism of virulence attenuation of glycosaminoglycan-binding variants of Japanese encephalitis virus and Murray Valley encephalitis virus. J. Virol. 2002, 76, 4901-4911. [CrossRef] [PubMed]

275. Lee, J.W.; Chu, J.J.; Ng, M.L. Quantifying the specific binding between West Nile virus envelope domain III protein and the cellular receptor $\alpha_{\mathrm{v}} \beta_{3}$ integrin. J. Biol. Chem. 2006, 281, 1352-1360. [CrossRef] [PubMed]

276. Li, L.; Barrett, A.D.; Beasley, D.W. Differential expression of domain III neutralizing epitopes on the envelope proteins of West Nile virus strains. Virology 2005, 335, 99-105. [CrossRef] [PubMed]

277. Pierson, T.C.; Xu, Q.; Nelson, S.; Oliphant, T.; Nybakken, G.E.; Fremont, D.H.; Diamond, M.S. The stoichiometry of antibody-mediated neutralization and enhancement of West Nile virus infection. Cell Host Microbe 2007, 1, 135-145. [CrossRef] [PubMed]

278. Rey, F.A.; Heinz, F.X.; Mandl, C.; Kunz, C.; Harrison, S.C. The envelope glycoprotein from tick-borne encephalitis virus at 2 A resolution. Nature 1995, 375, 291-298. [CrossRef] [PubMed]

279. Stiasny, K.; Kiermayr, S.; Holzmann, H.; Heinz, F.X. Cryptic properties of a cluster of dominant flavivirus cross-reactive antigenic sites. J. Virol. 2006, 80, 9557-9568. [CrossRef] [PubMed]

280. Sukupolvi-Petty, S.; Austin, S.K.; Purtha, W.E.; Oliphant, T.; Nybakken, G.E.; Schlesinger, J.J.; Roehrig, J.T.; Gromowski, G.D.; Barrett, A.D.; Fremont, D.H.; et al. Type- and subcomplex-specific neutralizing antibodies against domain III of dengue virus type 2 envelope protein recognize adjacent epitopes. J. Virol. 2007, 81, 12816-12826. [CrossRef] [PubMed] 
281. Wu, K.P.; Wu, C.W.; Tsao, Y.P.; Kuo, T.W.; Lou, Y.C.; Lin, C.W.; Wu, S.C.; Cheng, J.W. Structural basis of a flavivirus recognized by its neutralizing antibody: Solution structure of the domain III of the Japanese encephalitis virus envelope protein. J. Biol. Chem. 2003, 278, 46007-46013. [CrossRef] [PubMed]

282. Huang, C.Y.; Butrapet, S.; Moss, K.J.; Childers, T.; Erb, S.M.; Calvert, A.E.; Silengo, S.J.; Kinney, R.M.; Blair, C.D.; Roehrig, J.T. The dengue virus type 2 envelope protein fusion peptide is essential for membrane fusion. Virology 2010, 396, 305-315. [CrossRef] [PubMed]

283. Beltramello, M.; Williams, K.L.; Simmons, C.P.; Macagno, A.; Simonelli, L.; Quyen, N.T.; Sukupolvi-Petty, S.; Navarro-Sanchez, E.; Young, P.R.; de Silva, A.M.; et al. The human immune response to dengue virus is dominated by highly cross-reactive antibodies endowed with neutralizing and enhancing activity. Cell Host Microbe 2010, 8, 271-283. [CrossRef] [PubMed]

284. Chiou, S.S.; Fan, Y.C.; Crill, W.D.; Chang, R.Y.; Chang, G.J. Mutation analysis of the cross-reactive epitopes of Japanese encephalitis virus envelope glycoprotein. J. Gen. Virol. 2012, 93, 1185-1192. [CrossRef] [PubMed]

285. Fan, W.; Qian, P.; Wang, D.; Zhi, X.; Wei, Y.; Chen, H.; Li, X. Integrin $\alpha_{\mathrm{v}} \beta_{3}$ promotes infection by Japanese encephalitis virus. Res. Vet. Sci. 2017, 111, 67-74. [CrossRef] [PubMed]

286. Shimojima, M.; Takenouchi, A.; Shimoda, H.; Kimura, N.; Maeda, K. Distinct usage of three C-type lectins by Japanese encephalitis virus: DC-SIGN, DC-SIGNR, and LSECtin. Arch. Virol. 2014, 159, 2023-2031. [CrossRef] [PubMed]

287. Wang, P.; Hu, K.; Luo, S.; Zhang, M.; Deng, X.; Li, C.; Jin, W.; Hu, B.; He, S.; Li, M.; et al. DC-SIGN as an attachment factor mediates Japanese encephalitis virus infection of human dendritic cells via interaction with a single high-mannose residue of viral E glycoprotein. Virology 2016, 488, 108-119. [CrossRef] [PubMed]

288. Chu, J.J.; $\mathrm{Ng}, \mathrm{M} . \mathrm{L}$. Interaction of West Nile virus with $\alpha_{\mathrm{v}} \beta_{3}$ integrin mediates virus entry into cells. J. Biol. Chem. 2004, 279, 54533-54541. [CrossRef] [PubMed]

289. Hurrelbrink, R.J.; McMinn, P.C. Attenuation of Murray Valley encephalitis virus by site-directed mutagenesis of the hinge and putative receptor-binding regions of the envelope protein. J. Virol. 2001, 75, 7692-7702. [CrossRef] [PubMed]

290. Lee, E.; Lobigs, M. Substitutions at the putative receptor-binding site of an encephalitic flavivirus alter virulence and host cell tropism and reveal a role for glycosaminoglycans in entry. J. Virol. 2000, 74, 8867-8875. [CrossRef] [PubMed]

291. Lobigs, M.; Usha, R.; Nestorowicz, A.; Marshall, I.D.; Weir, R.C.; Dalgarno, L. Host cell selection of Murray Valley encephalitis virus variants altered at an RGD sequence in the envelope protein and in mouse virulence. Virology 1990, 176, 587-595. [CrossRef]

292. Van der Most, R.G.; Corver, J.; Strauss, J.H. Mutagenesis of the RGD motif in the yellow fever virus 17D envelope protein. Virology 1999, 265, 83-95. [CrossRef] [PubMed]

293. Barba-Spaeth, G.; Longman, R.S.; Albert, M.L.; Rice, C.M. Live attenuated yellow fever 17D infects human DCs and allows for presentation of endogenous and recombinant T cell epitopes. J. Exp. Med. 2005, 202, 1179-1184. [CrossRef] [PubMed]

294. Fontes-Garfias, C.R.; Shan, C.; Luo, H.; Muruato, A.E.; Medeiros, D.B.A.; Mays, E.; Xie, X.; Zou, J.; Roundy, C.M.; Wakamiya, M.; et al. Functional analysis of glycosylation of Zika virus envelope protein. Cell Rep. 2017, 21, 1180-1190. [CrossRef] [PubMed]

295. Liu, H.; Liu, Y.; Wang, S.; Zhang, Y.; Zu, X.; Zhou, Z.; Zhang, B.; Xiao, G. Structure-based mutational analysis of several sites in the E protein: Implications for understanding the entry mechanism of Japanese encephalitis virus. J. Virol. 2015, 89, 5668-5686. [CrossRef] [PubMed]

296. Luca, V.C.; AbiMansour, J.; Nelson, C.A.; Fremont, D.H. Crystal structure of the Japanese encephalitis virus envelope protein. J. Virol. 2012, 86, 2337-2346. [CrossRef] [PubMed]

297. Chiou, S.S.; Liu, H.; Chuang, C.K.; Lin, C.C.; Chen, W.J. Fitness of Japanese encephalitis virus to Neuro-2a cells is determined by interactions of the viral envelope protein with highly sulfated glycosaminoglycans on the cell surface. J. Med. Virol. 2005, 76, 583-592. [CrossRef] [PubMed]

298. Su, C.M.; Liao, C.L.; Lee, Y.L.; Lin, Y.L. Highly sulfated forms of heparin sulfate are involved in Japanese encephalitis virus infection. Virology 2001, 286, 206-215. [CrossRef] [PubMed]

299. Liu, H.; Chiou, S.S.; Chen, W.J. Differential binding efficiency between the envelope protein of Japanese encephalitis virus variants and heparan sulfate on the cell surface. J. Med. Virol. 2004, 72, 618-624. [CrossRef] [PubMed] 
300. Lee, E.; Hall, R.A.; Lobigs, M. Common E protein determinants for attenuation of glycosaminoglycan-binding variants of Japanese encephalitis and West Nile viruses. J. Virol. 2004, 78, 8271-8280. [CrossRef] [PubMed]

301. Nickells, J.; Cannella, M.; Droll, D.A.; Liang, Y.; Wold, W.S.; Chambers, T.J. Neuroadapted yellow fever virus strain 17D: A charged locus in domain III of the E protein governs heparin binding activity and neuroinvasiveness in the SCID mouse model. J. Virol. 2008, 82, 12510-12519. [CrossRef] [PubMed]

302. Germi, R.; Crance, J.M.; Garin, D.; Guimet, J.; Lortat-Jacob, H.; Ruigrok, R.W.; Zarski, J.P.; Drouet, E. Heparan sulfate-mediated binding of infectious dengue virus type 2 and yellow fever virus. Virology 2002, 292, 162-168. [CrossRef] [PubMed]

303. Hilgard, P.; Stockert, R. Heparan sulfate proteoglycans initiate dengue virus infection of hepatocytes. Hepatology 2000, 32, 1069-1077. [CrossRef] [PubMed]

304. Kroschewski, H.; Allison, S.L.; Heinz, F.X.; Mandl, C.W. Role of heparan sulfate for attachment and entry of tick-borne encephalitis virus. Virology 2003, 308, 92-100. [CrossRef]

305. Okamoto, K.; Kinoshita, H.; Parquet Mdel, C.; Raekiansyah, M.; Kimura, D.; Yui, K.; Islam, M.A.; Hasebe, F.; Morita, K. Dengue virus strain DEN2 16681 utilizes a specific glycochain of syndecan-2 proteoglycan as a receptor. J. Gen. Virol. 2012, 93, 761-770. [CrossRef] [PubMed]

306. Mandl, C.W.; Kroschewski, H.; Allison, S.L.; Kofler, R.; Holzmann, H.; Meixner, T.; Heinz, F.X. Adaptation of tick-borne encephalitis virus to BHK-21 cells results in the formation of multiple heparan sulfate binding sites in the envelope protein and attenuation in vivo. J. Virol. 2001, 75, 5627-5637. [CrossRef] [PubMed]

307. Roehrig, J.T.; Butrapet, S.; Liss, N.M.; Bennett, S.L.; Luy, B.E.; Childers, T.; Boroughs, K.L.; Stovall, J.L.; Calvert, A.E.; Blair, C.D.; et al. Mutation of the dengue virus type 2 envelope protein heparan sulfate binding sites or the domain III lateral ridge blocks replication in Vero cells prior to membrane fusion. Virology 2013, 441, 114-125. [CrossRef] [PubMed]

308. Watterson, D.; Kobe, B.; Young, P.R. Residues in domain III of the dengue virus envelope glycoprotein involved in cell-surface glycosaminoglycan binding. J. Gen. Virol. 2012, 93, 72-82. [CrossRef] [PubMed]

309. Kim, S.Y.; Zhao, J.; Liu, X.; Fraser, K.; Lin, L.; Zhang, X.; Zhang, F.; Dordick, J.S.; Linhardt, R.J. Interaction of Zika virus envelope protein with glycosaminoglycans. Biochemistry 2017, 56, 1151-1162. [CrossRef] [PubMed]

310. Martinez-Barragan, J.J.; del Angel, R.M. Identification of a putative coreceptor on Vero cells that participates in dengue 4 virus infection. J. Virol. 2001, 75, 7818-7827. [CrossRef] [PubMed]

311. Dalrymple, N.; Mackow, E.R. Productive dengue virus infection of human endothelial cells is directed by heparan sulfate-containing proteoglycan receptors. J. Virol. 2011, 85, 9478-9485. [CrossRef] [PubMed]

312. Hung, S.L.; Lee, P.L.; Chen, H.W.; Chen, L.K.; Kao, C.L.; King, C.C. Analysis of the steps involved in dengue virus entry into host cells. Virology 1999, 257, 156-167. [CrossRef] [PubMed]

313. Kamhi, E.; Joo, E.J.; Dordick, J.S.; Linhardt, R.J. Glycosaminoglycans in infectious disease. Biol. Rev. Camb. Philos. Soc. 2013, 88, 928-943. [CrossRef] [PubMed]

314. Belting, M. Heparan sulfate proteoglycan as a plasma membrane carrier. Trends Biochem. Sci. 2003, 28, 145-151. [CrossRef]

315. Chiou, S.S.; Chen, W.J. Phenotypic changes in the Japanese encephalitis virus after one passage in Neuro-2a cells: Generation of attenuated strains of the virus. Vaccine 2007, 26, 15-23. [CrossRef] [PubMed]

316. Mason, C.P.; Tarr, A.W. Human lectins and their roles in viral infections. Molecules 2015, 20, $2229-2271$. [CrossRef] [PubMed]

317. Zhang, F.; Ren, S.; Zuo, Y. DC-SIGN, DC-SIGNR and LSECtin: C-type lectins for infection. Int. Rev. Immunol. 2014, 33, 54-66. [CrossRef] [PubMed]

318. Geijtenbeek, T.B.; Kwon, D.S.; Torensma, R.; van Vliet, S.J.; van Duijnhoven, G.C.; Middel, J.; Cornelissen, I.L.; Nottet, H.S.; KewalRamani, V.N.; Littman, D.R.; et al. DC-SIGN, a dendritic cell-specific HIV-1-binding protein that enhances trans-infection of T cells. Cell 2000, 100, 587-597. [CrossRef]

319. Geijtenbeek, T.B.; Torensma, R.; van Vliet, S.J.; van Duijnhoven, G.C.; Adema, G.J.; van Kooyk, Y.; Figdor, C.G. Identification of DC-SIGN, a novel dendritic cell-specific ICAM-3 receptor that supports primary immune responses. Cell 2000, 100, 575-585. [CrossRef]

320. Engering, A.; van Vliet, S.J.; Hebeda, K.; Jackson, D.G.; Prevo, R.; Singh, S.K.; Geijtenbeek, T.B.; van Krieken, H.; van Kooyk, Y. Dynamic populations of dendritic cell-specific ICAM-3 grabbing nonintegrin-positive immature dendritic cells and liver/lymph node-specific ICAM-3 grabbing nonintegrin-positive endothelial cells in the outer zones of the paracortex of human lymph nodes. Am. J. Pathol. 2004, 164, 1587-1595. [CrossRef] 
321. Pohlmann, S.; Soilleux, E.J.; Baribaud, F.; Leslie, G.J.; Morris, L.S.; Trowsdale, J.; Lee, B.; Coleman, N.; Doms, R.W. DC-SIGNR, a DC-SIGN homologue expressed in endothelial cells, binds to human and simian immunodeficiency viruses and activates infection in trans. Proc. Natl. Acad. Sci. USA 2001, 98, 2670-2675. [CrossRef] [PubMed]

322. Bashirova, A.A.; Geijtenbeek, T.B.; van Duijnhoven, G.C.; van Vliet, S.J.; Eilering, J.B.; Martin, M.P.; Wu, L.; Martin, T.D.; Viebig, N.; Knolle, P.A.; et al. A dendritic cell-specific intercellular adhesion molecule 3-grabbing nonintegrin (DC-SIGN)-related protein is highly expressed on human liver sinusoidal endothelial cells and promotes HIV-1 infection. J. Exp. Med. 2001, 193, 671-678. [CrossRef] [PubMed]

323. Khoo, U.S.; Chan, K.Y.; Chan, V.S.; Lin, C.L. DC-SIGN and L-SIGN: The SIGNs for infection. J. Mol. Med. 2008, 86, 861-874. [CrossRef] [PubMed]

324. Davis, C.W.; Mattei, L.M.; Nguyen, H.Y.; Ansarah-Sobrinho, C.; Doms, R.W.; Pierson, T.C. The location of asparagine-linked glycans on West Nile virions controls their interactions with CD209 (dendritic cell-specific ICAM-3 grabbing nonintegrin). J. Biol. Chem. 2006, 281, 37183-37194. [CrossRef] [PubMed]

325. Mondotte, J.A.; Lozach, P.Y.; Amara, A.; Gamarnik, A.V. Essential role of dengue virus envelope protein $\mathrm{N}$-glycosylation at asparagine-67 during viral propagation. J. Virol. 2007, 81, 7136-7148. [CrossRef] [PubMed]

326. Dejnirattisai, W.; Webb, A.I.; Chan, V.; Jumnainsong, A.; Davidson, A.; Mongkolsapaya, J.; Screaton, G. Lectin switching during dengue virus infection. J. Infect. Dis. 2011, 203, 1775-1783. [CrossRef] [PubMed]

327. Lozach, P.Y.; Burleigh, L.; Staropoli, I.; Navarro-Sanchez, E.; Harriague, J.; Virelizier, J.L.; Rey, F.A.; Despres, P.; Arenzana-Seisdedos, F.; Amara, A. Dendritic cell-specific intercellular adhesion molecule 3-grabbing non-integrin (DC-SIGN)-mediated enhancement of dengue virus infection is independent of DC-SIGN internalization signals. J. Biol. Chem. 2005, 280, 23698-23708. [CrossRef] [PubMed]

328. Liu, P.; Ridilla, M.; Patel, P.; Betts, L.; Gallichotte, E.; Shahidi, L.; Thompson, N.L.; Jacobson, K. Beyond attachment: Roles of DC-SIGN in dengue virus infection. Traffic 2017, 18, 218-231. [CrossRef] [PubMed]

329. Shah, M.; Wadood, A.; Rahman, Z.; Husnain, T. Interaction and inhibition of dengue envelope glycoprotein with mammalian receptor DC-sign, an in-silico approach. PLoS ONE 2013, 8. [CrossRef] [PubMed]

330. Rey, F.A.; Stiasny, K.; Heinz, F.X. Flavivirus structural heterogeneity: Implications for cell entry. Curr. Opin. Virol. 2017, 24, 132-139. [CrossRef] [PubMed]

331. Pierson, T.C.; Diamond, M.S. Degrees of maturity: The complex structure and biology of flaviviruses. Curr. Opin. Virol. 2012, 2, 168-175. [CrossRef] [PubMed]

332. Kim, J.M.; Yun, S.I.; Song, B.H.; Hahn, Y.S.; Lee, C.H.; Oh, H.W.; Lee, Y.M. A single N-linked glycosylation site in the Japanese encephalitis virus prM protein is critical for cell type-specific prM protein biogenesis, virus particle release, and pathogenicity in mice. J. Virol. 2008, 82, 7846-7862. [CrossRef] [PubMed]

333. Pabalan, N.; Chaisri, S.; Tabunhan, S.; Phumyen, A.; Jarjanazi, H.; Steiner, T.S. Associations of DC-SIGN (CD209) promoter -336G/A polymorphism (rs4804803) with dengue infection: A systematic review and meta-analysis. Acta Trop. 2018, 177, 186-193. [CrossRef] [PubMed]

334. Barkhash, A.V.; Perelygin, A.A.; Babenko, V.N.; Brinton, M.A.; Voevoda, M.I. Single nucleotide polymorphism in the promoter region of the CD209 gene is associated with human predisposition to severe forms of tick-borne encephalitis. Antivir. Res. 2012, 93, 64-68. [CrossRef] [PubMed]

335. Miller, J.L.; de Wet, B.J.; Martinez-Pomares, L.; Radcliffe, C.M.; Dwek, R.A.; Rudd, P.M.; Gordon, S. The mannose receptor mediates dengue virus infection of macrophages. PLoS Pathog. 2008, 4. [CrossRef]

336. Chen, S.T.; Liu, R.S.; Wu, M.F.; Lin, Y.L.; Chen, S.Y.; Tan, D.T.; Chou, T.Y.; Tsai, I.S.; Li, L.; Hsieh, S.L. CLEC5A regulates Japanese encephalitis virus-induced neuroinflammation and lethality. PLoS Pathog. 2012, 8. [CrossRef] [PubMed]

337. Chen, S.T.; Lin, Y.L.; Huang, M.T.; Wu, M.F.; Cheng, S.C.; Lei, H.Y.; Lee, C.K.; Chiou, T.W.; Wong, C.H.; Hsieh, S.L. CLEC5A is critical for dengue virus-induced lethal disease. Nature 2008, 453, 672-676. [CrossRef] [PubMed]

338. Martinez-Pomares, L. The mannose receptor. J. Leukoc. Biol. 2012, 92, 1177-1186. [CrossRef] [PubMed]

339. Bakker, A.B.; Baker, E.; Sutherland, G.R.; Phillips, J.H.; Lanier, L.L. Myeloid DAP12-associating lectin (MDL)-1 is a cell surface receptor involved in the activation of myeloid cells. Proc. Natl. Acad. Sci. USA 1999, 96, 9792-9796. [CrossRef] [PubMed]

340. Lanier, L.L.; Corliss, B.C.; Wu, J.; Leong, C.; Phillips, J.H. Immunoreceptor DAP12 bearing a tyrosine-based activation motif is involved in activating NK cells. Nature 1998, 391, 703-707. [CrossRef] [PubMed] 
341. Dominguez-Soto, A.; Aragoneses-Fenoll, L.; Martin-Gayo, E.; Martinez-Prats, L.; Colmenares, M.; Naranjo-Gomez, M.; Borras, F.E.; Munoz, P.; Zubiaur, M.; Toribio, M.L.; et al. The DC-SIGN-related lectin LSECtin mediates antigen capture and pathogen binding by human myeloid cells. Blood 2007, 109, 5337-5345. [CrossRef] [PubMed]

342. Liu, K.; Qian, Y.; Jung, Y.S.; Zhou, B.; Cao, R.; Shen, T.; Shao, D.; Wei, J.; Ma, Z.; Chen, P.; et al. mosGCTL-7, a C-type lectin protein, mediates Japanese encephalitis virus infection in mosquitoes. J. Virol. $2017,91$. [CrossRef] [PubMed]

343. Cheng, G.; Cox, J.; Wang, P.; Krishnan, M.N.; Dai, J.; Qian, F.; Anderson, J.F.; Fikrig, E. A C-type lectin collaborates with a CD45 phosphatase homolog to facilitate West Nile virus infection of mosquitoes. Cell 2010, 142, 714-725. [CrossRef] [PubMed]

344. Liu, Y.; Zhang, F.; Liu, J.; Xiao, X.; Zhang, S.; Qin, C.; Xiang, Y.; Wang, P.; Cheng, G. Transmission-blocking antibodies against mosquito C-type lectins for dengue prevention. PLoS Pathog. 2014, 10. [CrossRef] [PubMed]

345. Thomas, M.L. The leukocyte common antigen family. Annu. Rev. Immunol. 1989, 7, 339-369. [CrossRef] [PubMed]

346. Byth, K.F.; Conroy, L.A.; Howlett, S.; Smith, A.J.; May, J.; Alexander, D.R.; Holmes, N. CD45-null transgenic mice reveal a positive regulatory role for CD45 in early thymocyte development, in the selection of CD4 ${ }^{+} \mathrm{CD} 8^{+}$ thymocytes, and B cell maturation. J. Exp. Med. 1996, 183, 1707-1718. [CrossRef] [PubMed]

347. Trowbridge, I.S.; Thomas, M.L. CD45: An emerging role as a protein tyrosine phosphatase required for lymphocyte activation and development. Annu. Rev. Immunol. 1994, 12, 85-116. [CrossRef] [PubMed]

348. Baldwin, T.A.; Ostergaard, H.L. Developmentally regulated changes in glucosidase II association with, and carbohydrate content of, the protein tyrosine phosphatase CD45. J. Immunol. 2001, 167, 3829-3835. [CrossRef] [PubMed]

349. Luo, H.; Wang, T. Recent advances in understanding West Nile virus host immunity and viral pathogenesis. F1000Research 2018, 7. [CrossRef] [PubMed]

350. Fuchs, A.; Lin, T.Y.; Beasley, D.W.; Stover, C.M.; Schwaeble, W.J.; Pierson, T.C.; Diamond, M.S. Direct complement restriction of flavivirus infection requires glycan recognition by mannose-binding lectin. Cell Host Microbe 2010, 8, 186-195. [CrossRef] [PubMed]

351. Figueiredo, G.G.; Cezar, R.D.; Freire, N.M.; Teixeira, V.G.; Baptista, P.; Cordeiro, M.; Carmo, R.F.; Vasconcelos, L.R.; Moura, P. Mannose-binding lectin gene (MBL2) polymorphisms related to the mannose-binding lectin low levels are associated to dengue disease severity. Hum. Immunol. 2016, 77, 571-575. [CrossRef] [PubMed]

352. Pandolfi, F.; Franza, L.; Altamura, S.; Mandolini, C.; Cianci, R.; Ansari, A.; Kurnick, J.T. Integrins: Integrating the biology and therapy of cell-cell interactions. Clin. Ther. 2017, 39, 2420-2436. [CrossRef] [PubMed]

353. Chu, J.J.; Ng, M.L. Characterization of a 105-kDa plasma membrane associated glycoprotein that is involved in West Nile virus binding and infection. Virology 2003, 312, 458-469. [CrossRef]

354. Medigeshi, G.R.; Hirsch, A.J.; Streblow, D.N.; Nikolich-Zugich, J.; Nelson, J.A. West Nile virus entry requires cholesterol-rich membrane microdomains and is independent of $\alpha_{\mathrm{v}} \beta_{3}$ integrin. J. Virol. 2008, 82, 5212-5219. [CrossRef] [PubMed]

355. Schmidt, K.; Keller, M.; Bader, B.L.; Korytar, T.; Finke, S.; Ziegler, U.; Groschup, M.H. Integrins modulate the infection efficiency of West Nile virus into cells. J. Gen. Virol. 2013, 94, 1723-1733. [CrossRef] [PubMed]

356. Horvath, I.; Multhoff, G.; Sonnleitner, A.; Vigh, L. Membrane-associated stress proteins: More than simply chaperones. Biochim. Biophys. Acta 2008, 1778, 1653-1664. [CrossRef] [PubMed]

357. Ren, J.; Ding, T.; Zhang, W.; Song, J.; Ma, W. Does Japanese encephalitis virus share the same cellular receptor with other mosquito-borne flaviviruses on the C6/36 mosquito cells? Virol. J. 2007, 4. [CrossRef] [PubMed]

358. Das, S.; Laxminarayana, S.V.; Chandra, N.; Ravi, V.; Desai, A. Heat shock protein 70 on Neuro2a cells is a putative receptor for Japanese encephalitis virus. Virology 2009, 385, 47-57. [CrossRef] [PubMed]

359. Zhu, Y.Z.; Cao, M.M.; Wang, W.B.; Wang, W.; Ren, H.; Zhao, P.; Qi, Z.T. Association of heat shock protein 70 with lipid rafts is required for Japanese encephalitis virus infection in Huh7 cells. J. Gen. Virol. 2012, 93, 61-71. [CrossRef] [PubMed]

360. Nain, M.; Mukherjee, S.; Karmakar, S.P.; Paton, A.W.; Paton, J.C.; Abdin, M.Z.; Basu, A.; Kalia, M.; Vrati, S. GRP78 is an important host factor for Japanese encephalitis virus entry and replication in mammalian cells. J. Virol. 2017, 91. [CrossRef] [PubMed] 
361. Hung, C.Y.; Tsai, M.C.; Wu, Y.P.; Wang, R.Y. Identification of heat-shock protein $90 \beta$ in Japanese encephalitis virus-induced secretion proteins. J. Gen. Virol. 2011, 92, 2803-2809. [CrossRef] [PubMed]

362. Thongtan, T.; Wikan, N.; Wintachai, P.; Rattanarungsan, C.; Srisomsap, C.; Cheepsunthorn, P.; Smith, D.R. Characterization of putative Japanese encephalitis virus receptor molecules on microglial cells. J. Med. Virol. 2012, 84, 615-623. [CrossRef] [PubMed]

363. Reyes-Del Valle, J.; Chavez-Salinas, S.; Medina, F.; Del Angel, R.M. Heat shock protein 90 and heat shock protein 70 are components of dengue virus receptor complex in human cells. J. Virol. 2005, 79, 4557-4567. [CrossRef] [PubMed]

364. Cabrera-Hernandez, A.; Thepparit, C.; Suksanpaisan, L.; Smith, D.R. Dengue virus entry into liver (HepG2) cells is independent of hsp90 and hsp70. J. Med. Virol. 2007, 79, 386-392. [CrossRef] [PubMed]

365. Salas-Benito, J.; Reyes-Del Valle, J.; Salas-Benito, M.; Ceballos-Olvera, I.; Mosso, C.; del Angel, R.M. Evidence that the $45-\mathrm{kD}$ glycoprotein, part of a putative dengue virus receptor complex in the mosquito cell line C6/36, is a heat-shock related protein. Am. J. Trop. Med. Hyg. 2007, 77, 283-290. [PubMed]

366. Jindadamrongwech, S.; Thepparit, C.; Smith, D.R. Identification of GRP78 (BiP) as a liver cell expressed receptor element for dengue virus serotype 2. Arch. Virol. 2004, 149, 915-927. [CrossRef] [PubMed]

367. Vega-Almeida, T.O.; Salas-Benito, M.; De Nova-Ocampo, M.A.; Del Angel, R.M.; Salas-Benito, J.S. Surface proteins of C6/36 cells involved in dengue virus 4 binding and entry. Arch. Virol. 2013, 158, 1189-1207. [CrossRef] [PubMed]

368. Taguwa, S.; Maringer, K.; Li, X.; Bernal-Rubio, D.; Rauch, J.N.; Gestwicki, J.E.; Andino, R.; Fernandez-Sesma, A.; Frydman, J. Defining hsp70 subnetworks in dengue virus replication reveals key vulnerability in flavivirus infection. Cell 2015, 163, 1108-1123. [CrossRef] [PubMed]

369. Upanan, S.; Kuadkitkan, A.; Smith, D.R. Identification of dengue virus binding proteins using affinity chromatography. J. Virol. Methods 2008, 151, 325-328. [CrossRef] [PubMed]

370. Howe, M.K.; Speer, B.L.; Hughes, P.F.; Loiselle, D.R.; Vasudevan, S.; Haystead, T.A. An inducible heat shock protein 70 small molecule inhibitor demonstrates anti-dengue virus activity, validating Hsp70 as a host antiviral target. Antivir. Res. 2016, 130, 81-92. [CrossRef] [PubMed]

371. Liang, J.J.; Yu, C.Y.; Liao, C.L.; Lin, Y.L. Vimentin binding is critical for infection by the virulent strain of Japanese encephalitis virus. Cell. Microbiol. 2011, 13, 1358-1370. [CrossRef] [PubMed]

372. Chen, L.K.; Lin, Y.L.; Liao, C.L.; Lin, C.G.; Huang, Y.L.; Yeh, C.T.; Lai, S.C.; Jan, J.T.; Chin, C. Generation and characterization of organ-tropism mutants of Japanese encephalitis virus in vivo and In vitro. Virology 1996, 223, 79-88. [CrossRef] [PubMed]

373. Das, S.; Ravi, V.; Desai, A. Japanese encephalitis virus interacts with vimentin to facilitate its entry into porcine kidney cell line. Virus Res. 2011, 160, 404-408. [CrossRef] [PubMed]

374. Chien, Y.J.; Chen, W.J.; Hsu, W.L.; Chiou, S.S. Bovine lactoferrin inhibits Japanese encephalitis virus by binding to heparan sulfate and receptor for low density lipoprotein. Virology 2008, 379, 143-151. [CrossRef] [PubMed]

375. Kimura, T.; Kimura-Kuroda, J.; Nagashima, K.; Yasui, K. Analysis of virus-cell binding characteristics on the determination of Japanese encephalitis virus susceptibility. Arch. Virol. 1994, 139, 239-251. [CrossRef] [PubMed]

376. Boonsanay, V.; Smith, D.R. Entry into and production of the Japanese encephalitis virus from C6/36 cells. Intervirology 2007, 50, 85-92. [CrossRef] [PubMed]

377. Meertens, L.; Carnec, X.; Lecoin, M.P.; Ramdasi, R.; Guivel-Benhassine, F.; Lew, E.; Lemke, G.; Schwartz, O.; Amara, A. The TIM and TAM families of phosphatidylserine receptors mediate dengue virus entry. Cell Host Microbe 2012, 12, 544-557. [CrossRef] [PubMed]

378. Jemielity, S.; Wang, J.J.; Chan, Y.K.; Ahmed, A.A.; Li, W.; Monahan, S.; Bu, X.; Farzan, M.; Freeman, G.J.; Umetsu, D.T.; et al. TIM-family proteins promote infection of multiple enveloped viruses through virion-associated phosphatidylserine. PLoS Pathog. 2013, 9. [CrossRef] [PubMed]

379. Morizono, K.; Chen, I.S. Role of phosphatidylserine receptors in enveloped virus infection. J. Virol. 2014, 88, 4275-4290. [CrossRef] [PubMed]

380. Richard, A.S.; Zhang, A.; Park, S.J.; Farzan, M.; Zong, M.; Choe, H. Virion-associated phosphatidylethanolamine promotes TIM1-mediated infection by Ebola, dengue, and West Nile viruses. Proc. Natl. Acad. Sci. USA 2015, 112, 14682-14687. [CrossRef] [PubMed] 
381. Savidis, G.; McDougall, W.M.; Meraner, P.; Perreira, J.M.; Portmann, J.M.; Trincucci, G.; John, S.P.; Aker, A.M.; Renzette, N.; Robbins, D.R.; et al. Identification of Zika virus and dengue virus dependency factors using functional genomics. Cell Rep. 2016, 16, 232-246. [CrossRef] [PubMed]

382. Persaud, M.; Martinez-Lopez, A.; Buffone, C.; Porcelli, S.A.; Diaz-Griffero, F. Infection by Zika viruses requires the transmembrane protein AXL, endocytosis and low pH. Virology 2018, 518, 301-312. [CrossRef] [PubMed]

383. Meertens, L.; Labeau, A.; Dejarnac, O.; Cipriani, S.; Sinigaglia, L.; Bonnet-Madin, L.; Le Charpentier, T.; Hafirassou, M.L.; Zamborlini, A.; Cao-Lormeau, V.M.; et al. Axl mediates Zika virus entry in human glial cells and modulates innate immune responses. Cell Rep. 2017, 18, 324-333. [CrossRef] [PubMed]

384. Richard, A.S.; Shim, B.S.; Kwon, Y.C.; Zhang, R.; Otsuka, Y.; Schmitt, K.; Berri, F.; Diamond, M.S.; Choe, H. AXL-dependent infection of human fetal endothelial cells distinguishes Zika virus from other pathogenic flaviviruses. Proc. Natl. Acad. Sci. USA 2017, 114, 2024-2029. [CrossRef] [PubMed]

385. Liu, S.; DeLalio, L.J.; Isakson, B.E.; Wang, T.T. AXL-mediated productive infection of human endothelial cells by Zika virus. Circ. Res. 2016, 119, 1183-1189. [CrossRef] [PubMed]

386. Nowakowski, T.J.; Pollen, A.A.; Di Lullo, E.; Sandoval-Espinosa, C.; Bershteyn, M.; Kriegstein, A.R. Expression analysis highlights AXL as a candidate Zika virus entry receptor in neural stem cells. Cell Stem Cell 2016, 18, 591-596. [CrossRef] [PubMed]

387. Wang, Z.Y.; Wang, Z.; Zhen, Z.D.; Feng, K.H.; Guo, J.; Gao, N.; Fan, D.Y.; Han, D.S.; Wang, P.G.; An, J. Axl is not an indispensable factor for Zika virus infection in mice. J. Gen. Virol. 2017, 98, 2061-2068. [CrossRef] [PubMed]

388. Hastings, A.K.; Yockey, L.J.; Jagger, B.W.; Hwang, J.; Uraki, R.; Gaitsch, H.F.; Parnell, L.A.; Cao, B.; Mysorekar, I.U.; Rothlin, C.V.; et al. TAM receptors are not required for Zika virus infection in mice. Cell Rep. 2017, 19, 558-568. [CrossRef] [PubMed]

389. Carnec, X.; Meertens, L.; Dejarnac, O.; Perera-Lecoin, M.; Hafirassou, M.L.; Kitaura, J.; Ramdasi, R.; Schwartz, O.; Amara, A. The phosphatidylserine and phosphatidylethanolamine receptor CD300a binds dengue virus and enhances infection. J. Virol. 2016, 90, 92-102. [CrossRef] [PubMed]

390. Che, P.; Tang, H.; Li, Q. The interaction between claudin-1 and dengue viral prM/M protein for its entry. Virology 2013, 446, 303-313. [CrossRef] [PubMed]

391. Gao, F.; Duan, X.; Lu, X.; Liu, Y.; Zheng, L.; Ding, Z.; Li, J. Novel binding between pre-membrane protein and claudin-1 is required for efficient dengue virus entry. Biochem. Biophys. Res. Commun. 2010, 391, 952-957. [CrossRef] [PubMed]

392. Li, Y.; Kakinami, C.; Li, Q.; Yang, B.; Li, H. Human apolipoprotein A-I is associated with dengue virus and enhances virus infection through SR-BI. PLOS ONE 2013, 8. [CrossRef] [PubMed]

393. Thepparit, C.; Smith, D.R. Serotype-specific entry of dengue virus into liver cells: Identification of the 37-kilodalton/67-kilodalton high-affinity laminin receptor as a dengue virus serotype 1 receptor. J. Virol. 2004, 78, 12647-12656. [CrossRef] [PubMed]

394. Sakoonwatanyoo, P.; Boonsanay, V.; Smith, D.R. Growth and production of the dengue virus in C6/36 cells and identification of a laminin-binding protein as a candidate serotype 3 and 4 receptor protein. Intervirology 2006, 49, 161-172. [CrossRef] [PubMed]

395. Chen, Y.C.; Wang, S.Y.; King, C.C. Bacterial lipopolysaccharide inhibits dengue virus infection of primary human monocytes/macrophages by blockade of virus entry via a CD14-dependent mechanism. J. Virol. 1999, 73, 2650-2657. [PubMed]

396. Aoki, C.; Hidari, K.I.; Itonori, S.; Yamada, A.; Takahashi, N.; Kasama, T.; Hasebe, F.; Islam, M.A.; Hatano, K.; Matsuoka, K.; et al. Identification and characterization of carbohydrate molecules in mammalian cells recognized by dengue virus type 2. J. Biochem. 2006, 139, 607-614. [CrossRef] [PubMed]

397. Wichit, S.; Jittmittraphap, A.; Hidari, K.I.; Thaisomboonsuk, B.; Petmitr, S.; Ubol, S.; Aoki, C.; Itonori, S.; Morita, K.; Suzuki, T.; et al. Dengue virus type 2 recognizes the carbohydrate moiety of neutral glycosphingolipids in mammalian and mosquito cells. Microbiol. Immunol. 2011, 55, 135-140. [CrossRef] [PubMed]

398. Hershkovitz, O.; Rosental, B.; Rosenberg, L.A.; Navarro-Sanchez, M.E.; Jivov, S.; Zilka, A.; Gershoni-Yahalom, O.; Brient-Litzler, E.; Bedouelle, H.; Ho, J.W.; et al. NKp44 receptor mediates interaction of the envelope glycoproteins from the West Nile and dengue viruses with NK cells. J. Immunol. 2009, 183, 2610-2621. [CrossRef] [PubMed] 
399. Kuadkitkan, A.; Wikan, N.; Fongsaran, C.; Smith, D.R. Identification and characterization of prohibitin as a receptor protein mediating DENV-2 entry into insect cells. Virology 2010, 406, 149-161. [CrossRef] [PubMed]

400. Cruz-Oliveira, C.; Freire, J.M.; Conceicao, T.M.; Higa, L.M.; Castanho, M.A.; Da Poian, A.T. Receptors and routes of dengue virus entry into the host cells. FEMS Microbiol. Rev. 2015, 39, 155-170. [CrossRef] [PubMed]

401. Mayor, S.; Pagano, R.E. Pathways of clathrin-independent endocytosis. Nat. Rev. Mol. Cell Biol. 2007, 8 , 603-612. [CrossRef] [PubMed]

402. Krishnan, M.N.; Sukumaran, B.; Pal, U.; Agaisse, H.; Murray, J.L.; Hodge, T.W.; Fikrig, E. Rab5 is required for the cellular entry of dengue and West Nile viruses. J. Virol. 2007, 81, 4881-4885. [CrossRef] [PubMed]

403. Acosta, E.G.; Castilla, V.; Damonte, E.B. Infectious dengue-1 virus entry into mosquito C6/36 cells. Virus Res. 2011, 160, 173-179. [CrossRef] [PubMed]

404. Acosta, E.G.; Castilla, V.; Damonte, E.B. Alternative infectious entry pathways for dengue virus serotypes into mammalian cells. Cell. Microbiol. 2009, 11, 1533-1549. [CrossRef] [PubMed]

405. Alhoot, M.A.; Wang, S.M.; Sekaran, S.D. RNA interference mediated inhibition of dengue virus multiplication and entry in HepG2 cells. PLoS ONE 2012, 7. [CrossRef] [PubMed]

406. Peng, T.; Wang, J.L.; Chen, W.; Zhang, J.L.; Gao, N.; Chen, Z.T.; Xu, X.F.; Fan, D.Y.; An, J. Entry of dengue virus serotype 2 into ECV304 cells depends on clathrin-dependent endocytosis, but not on caveolae-dependent endocytosis. Can. J. Microbiol. 2009, 55, 139-145. [CrossRef] [PubMed]

407. Alhoot, M.A.; Wang, S.M.; Sekaran, S.D. Inhibition of dengue virus entry and multiplication into monocytes using RNA interference. PLoS Negl. Trop. Dis. 2011, 5. [CrossRef] [PubMed]

408. Geoghegan, V.; Stainton, K.; Rainey, S.M.; Ant, T.H.; Dowle, A.A.; Larson, T.; Hester, S.; Charles, P.D.; Thomas, B.; Sinkins, S.P. Perturbed cholesterol and vesicular trafficking associated with dengue blocking in Wolbachia-infected Aedes aegypti cells. Nat. Commun. 2017, 8. [CrossRef] [PubMed]

409. Wang, J.L.; Zhang, J.L.; Chen, W.; Xu, X.F.; Gao, N.; Fan, D.Y.; An, J. Roles of small GTPase Rac1 in the regulation of actin cytoskeleton during dengue virus infection. PLoS Negl. Trop. Dis. 2010, 4. [CrossRef] [PubMed]

410. Shrivastava, N.; Sripada, S.; Kaur, J.; Shah, P.S.; Cecilia, D. Insights into the internalization and retrograde trafficking of dengue 2 virus in BHK-21 cells. PLoS ONE 2011, 6. [CrossRef] [PubMed]

411. Fernandez-Garcia, M.D.; Meertens, L.; Chazal, M.; Hafirassou, M.L.; Dejarnac, O.; Zamborlini, A.; Despres, P.; Sauvonnet, N.; Arenzana-Seisdedos, F.; Jouvenet, N.; et al. Vaccine and wild-type strains of yellow fever virus engage distinct entry mechanisms and differentially stimulate antiviral immune responses. mBio 2016, 7. [CrossRef] [PubMed]

412. Robinson, M.S. Forty years of clathrin-coated vesicles. Traffic 2015, 16, 1210-1238. [CrossRef] [PubMed]

413. Mercer, J.; Schelhaas, M.; Helenius, A. Virus entry by endocytosis. Annu. Rev. Biochem. 2010, 79, $803-833$. [CrossRef] [PubMed]

414. McMahon, H.T.; Boucrot, E. Molecular mechanism and physiological functions of clathrin-mediated endocytosis. Nat. Rev. Mol. Cell Biol. 2011, 12, 517-533. [CrossRef] [PubMed]

415. Krishnan, M.N.; Ng, A.; Sukumaran, B.; Gilfoy, F.D.; Uchil, P.D.; Sultana, H.; Brass, A.L.; Adametz, R.; Tsui, M.; Qian, F.; et al. RNA interference screen for human genes associated with West Nile virus infection. Nature 2008, 455, 242-245. [CrossRef] [PubMed]

416. Sessions, O.M.; Barrows, N.J.; Souza-Neto, J.A.; Robinson, T.J.; Hershey, C.L.; Rodgers, M.A.; Ramirez, J.L.; Dimopoulos, G.; Yang, P.L.; Pearson, J.L.; et al. Discovery of insect and human dengue virus host factors. Nature 2009, 458, 1047-1050. [CrossRef] [PubMed]

417. Le Sommer, C.; Barrows, N.J.; Bradrick, S.S.; Pearson, J.L.; Garcia-Blanco, M.A. G protein-coupled receptor kinase 2 promotes flaviviridae entry and replication. PLoS Negl. Trop. Dis. 2012, 6. [CrossRef] [PubMed]

418. Bekerman, E.; Neveu, G.; Shulla, A.; Brannan, J.; Pu, S.Y.; Wang, S.; Xiao, F.; Barouch-Bentov, R.; Bakken, R.R.; Mateo, R.; et al. Anticancer kinase inhibitors impair intracellular viral trafficking and exert broad-spectrum antiviral effects. J. Clin. Investig. 2017, 127, 1338-1352. [CrossRef] [PubMed]

419. Schoggins, J.W.; Wilson, S.J.; Panis, M.; Murphy, M.Y.; Jones, C.T.; Bieniasz, P.; Rice, C.M. A diverse range of gene products are effectors of the type I interferon antiviral response. Nature 2011, 472, 481-485. [CrossRef] [PubMed]

420. Hackett, B.A.; Cherry, S. Flavivirus internalization is regulated by a size-dependent endocytic pathway. Proc. Natl. Acad. Sci. USA 2018, 115, 4246-4251. [CrossRef] [PubMed] 
421. Hackett, B.A.; Yasunaga, A.; Panda, D.; Tartell, M.A.; Hopkins, K.C.; Hensley, S.E.; Cherry, S. RNASEK is required for internalization of diverse acid-dependent viruses. Proc. Natl. Acad. Sci. USA 2015, 112, 7797-7802. [CrossRef] [PubMed]

422. Perreira, J.M.; Aker, A.M.; Savidis, G.; Chin, C.R.; McDougall, W.M.; Portmann, J.M.; Meraner, P.; Smith, M.C.; Rahman, M.; Baker, R.E.; et al. RNASEK is a V-ATPase-associated factor required for endocytosis and the replication of rhinovirus, influenza A virus, and dengue virus. Cell Rep. 2015, 12, 850-863. [CrossRef] [PubMed]

423. Harrison, S.C. Viral membrane fusion. Nat. Struct. Mol. Biol. 2008, 15, 690-698. [CrossRef] [PubMed]

424. Hasan, S.S.; Sevvana, M.; Kuhn, R.J.; Rossmann, M.G. Structural biology of Zika virus and other flaviviruses. Nat. Struct. Mol. Biol. 2018, 25, 13-20. [CrossRef] [PubMed]

425. Smit, J.M.; Moesker, B.; Rodenhuis-Zybert, I.; Wilschut, J. Flavivirus cell entry and membrane fusion. Viruses 2011, 3, 160-171. [CrossRef] [PubMed]

426. Liu, X.; Zhao, X.; Na, R.; Li, L.; Warkentin, E.; Witt, J.; Lu, X.; Yu, Y.; Wei, Y.; Peng, G.; et al. The structure differences of Japanese encephalitis virus $\mathrm{SA}_{14}$ and $\mathrm{SA}_{14}$-14-2 E proteins elucidate the virulence attenuation mechanism. Protein Cell 2018. [CrossRef] [PubMed]

427. Kanai, R.; Kar, K.; Anthony, K.; Gould, L.H.; Ledizet, M.; Fikrig, E.; Marasco, W.A.; Koski, R.A.; Modis, Y. Crystal structure of West Nile virus envelope glycoprotein reveals viral surface epitopes. J. Virol. 2006, 80, 11000-11008. [CrossRef] [PubMed]

428. Nybakken, G.E.; Nelson, C.A.; Chen, B.R.; Diamond, M.S.; Fremont, D.H. Crystal structure of the West Nile virus envelope glycoprotein. J. Virol. 2006, 80, 11467-11474. [CrossRef] [PubMed]

429. Luca, V.C.; Nelson, C.A.; Fremont, D.H. Structure of the St. Louis encephalitis virus postfusion envelope trimer. J. Virol. 2013, 87, 818-828. [CrossRef] [PubMed]

430. Dai, L.; Song, J.; Lu, X.; Deng, Y.Q.; Musyoki, A.M.; Cheng, H.; Zhang, Y.; Yuan, Y.; Song, H.; Haywood, J.; et al. Structures of the Zika virus envelope protein and its complex with a flavivirus broadly protective antibody. Cell Host Microbe 2016, 19, 696-704. [CrossRef] [PubMed]

431. Modis, Y.; Ogata, S.; Clements, D.; Harrison, S.C. A ligand-binding pocket in the dengue virus envelope glycoprotein. Proc. Natl. Acad. Sci. USA 2003, 100, 6986-6991. [CrossRef] [PubMed]

432. Modis, Y.; Ogata, S.; Clements, D.; Harrison, S.C. Variable surface epitopes in the crystal structure of dengue virus type 3 envelope glycoprotein. J. Virol. 2005, 79, 1223-1231. [CrossRef] [PubMed]

433. Cockburn, J.J.; Navarro Sanchez, M.E.; Goncalvez, A.P.; Zaitseva, E.; Stura, E.A.; Kikuti, C.M.; Duquerroy, S.; Dussart, P.; Chernomordik, L.V.; Lai, C.J.; et al. Structural insights into the neutralization mechanism of a higher primate antibody against dengue virus. EMBO J. 2012, 31, 767-779. [CrossRef] [PubMed]

434. Stiasny, K.; Bressanelli, S.; Lepault, J.; Rey, F.A.; Heinz, F.X. Characterization of a membrane-associated trimeric low-pH-induced form of the class II viral fusion protein E from tick-borne encephalitis virus and its crystallization. J. Virol. 2004, 78, 3178-3183. [CrossRef] [PubMed]

435. Kaufmann, B.; Rossmann, M.G. Molecular mechanisms involved in the early steps of flavivirus cell entry. Microbes Infect. 2011, 13, 1-9. [CrossRef] [PubMed]

436. Kaufmann, B.; Chipman, P.R.; Holdaway, H.A.; Johnson, S.; Fremont, D.H.; Kuhn, R.J.; Diamond, M.S.; Rossmann, M.G. Capturing a flavivirus pre-fusion intermediate. PLoS Pathog. 2009, 5. [CrossRef] [PubMed]

437. Lin, S.R.; Zou, G.; Hsieh, S.C.; Qing, M.; Tsai, W.Y.; Shi, P.Y.; Wang, W.K. The helical domains of the stem region of dengue virus envelope protein are involved in both virus assembly and entry. J. Virol. 2011, 85, 5159-5171. [CrossRef] [PubMed]

438. Pangerl, K.; Heinz, F.X.; Stiasny, K. Mutational analysis of the zippering reaction during flavivirus membrane fusion. J. Virol. 2011, 85, 8495-8501. [CrossRef] [PubMed]

439. Schmidt, A.G.; Yang, P.L.; Harrison, S.C. Peptide inhibitors of dengue virus entry target a late-stage fusion intermediate. PLoS Pathog. 2010, 6. [CrossRef] [PubMed]

440. Schmidt, A.G.; Yang, P.L.; Harrison, S.C. Peptide inhibitors of flavivirus entry derived from the E protein stem. J. Virol. 2010, 84, 12549-12554. [CrossRef] [PubMed]

441. Stiasny, K.; Kiermayr, S.; Bernhart, A.; Heinz, F.X. The membrane-proximal "stem" region increases the stability of the flavivirus E protein postfusion trimer and modulates its structure. J. Virol. 2013, 87, 9933-9938. [CrossRef] [PubMed]

442. Rey, F.A.; Stiasny, K.; Vaney, M.C.; Dellarole, M.; Heinz, F.X. The bright and the dark side of human antibody responses to flaviviruses: Lessons for vaccine design. EMBO Rep. 2018, 19, 206-224. [CrossRef] [PubMed] 
443. Wang, S.; Liu, H.; Zu, X.; Liu, Y.; Chen, L.; Zhu, X.; Zhang, L.; Zhou, Z.; Xiao, G.; Wang, W. The ubiquitin-proteasome system is essential for the productive entry of Japanese encephalitis virus. Virology 2016, 498, 116-127. [CrossRef] [PubMed]

444. Nour, A.M.; Li, Y.; Wolenski, J.; Modis, Y. Viral membrane fusion and nucleocapsid delivery into the cytoplasm are distinct events in some flaviviruses. PLoS Pathog. 2013, 9. [CrossRef] [PubMed]

445. Byk, L.A.; Iglesias, N.G.; De Maio, F.A.; Gebhard, L.G.; Rossi, M.; Gamarnik, A.V. Dengue virus genome uncoating requires ubiquitination. mBio 2016, 7. [CrossRef] [PubMed]

446. Fernandez-Garcia, M.D.; Meertens, L.; Bonazzi, M.; Cossart, P.; Arenzana-Seisdedos, F.; Amara, A. Appraising the roles of CBLL1 and the ubiquitin/proteasome system for flavivirus entry and replication. J. Virol. 2011, 85, 2980-2989. [CrossRef] [PubMed]

447. Hase, T.; Summers, P.L.; Ray, P. Entry and replication of Japanese encephalitis virus in cultured neurogenic cells. J. Virol. Methods 1990, 30, 205-214. [CrossRef]

(C) 2018 by the authors. Licensee MDPI, Basel, Switzerland. This article is an open access article distributed under the terms and conditions of the Creative Commons Attribution (CC BY) license (http://creativecommons.org/licenses/by/4.0/). 